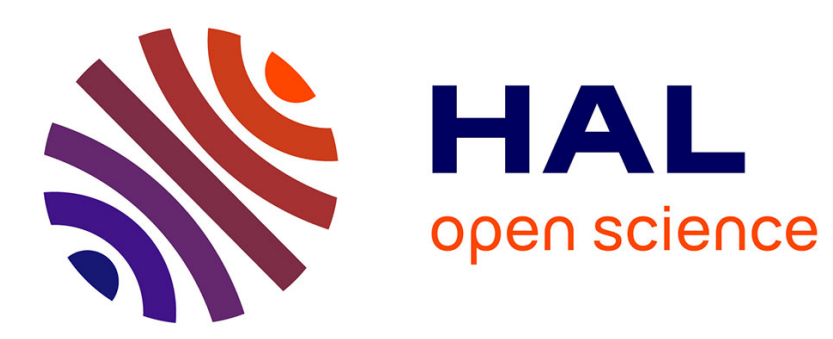

\title{
A critical review on the impacts of nanoplastics and microplastics on aquatic and terrestrial photosynthetic organisms
}

Camille Larue, Geraldine Sarret, Hiram Castillo-Michel, Ana Elena Pradas, Del Real

\section{To cite this version:}

Camille Larue, Geraldine Sarret, Hiram Castillo-Michel, Ana Elena Pradas, Del Real. A critical review on the impacts of nanoplastics and microplastics on aquatic and terrestrial photosynthetic organisms. Small, 2021, 10.1002/smll.202005834 . hal-03373004

\section{HAL Id: hal-03373004 https://hal.science/hal-03373004}

Submitted on 11 Oct 2021

HAL is a multi-disciplinary open access archive for the deposit and dissemination of scientific research documents, whether they are published or not. The documents may come from teaching and research institutions in France or abroad, or from public or private research centers.
L'archive ouverte pluridisciplinaire HAL, est destinée au dépôt et à la diffusion de documents scientifiques de niveau recherche, publiés ou non, émanant des établissements d'enseignement et de recherche français ou étrangers, des laboratoires publics ou privés. 
A critical review on the impacts of nanoplastics and microplastics on aquatic and terrestrial photosynthetic organisms

\author{
Camille Larue $^{\mathrm{a}^{*}}$, Géraldine Sarret $^{\mathrm{b}}$, Hiram Castillo-Michel $^{\mathrm{c}}$, Ana Elena Pradas del Real ${ }^{\mathrm{d}}$
}

${ }^{\text {a} L a b o r a t o i r e ~ E c o l o g i e ~ F o n c t i o n n e l l e ~ e t ~ E n v i r o n n e m e n t, ~ U n i v e r s i t e ́ ~ d e ~ T o u l o u s e, ~ C N R S, ~}$ Toulouse, France. camille.larue@ensat.fr

${ }^{\mathrm{b}}$ ISTerre (Institut des Sciences de la Terre), Univ. Grenoble Alpes, CNRS, 38000 Grenoble, France. geraldine.sarret@univ-grenoble-alpes.fr

${ }^{\mathrm{c}}$ ESRF The European Synchrotron, CS 40220, 38043 Grenoble Cedex 9, France. hiram.castillo_michel@esrf.fr

${ }^{\mathrm{d} D e p a r t m e n t ~ o f ~ A g r o e n v i r o n m e n t a l ~ R e s e a r c h . ~ I M I D R A, ~ A l c a l a ́ ~ d e ~ H e n a r e s, ~} 28800$ Madrid, Spain.ana.elena.pradas@madrid.es

* corresponding author

\begin{abstract}
Microplastic and nanoplastic contamination is widespread and affects aquatic and terrestrial ecosystems. Photosynthetic organisms are present in both media, they are primary producers, sink for $\mathrm{CO}_{2}$, and they represent a major point of entry in the food chain. Here, the current knowledge on the fate and impacts of microplastics and nanoplastics in interaction with these organisms has been reviewed. As a general trend, plastic characteristics (smaller size and positive charge) play a crucial role in their toxicity towards photosynthetic organisms. Plastic leachates (containing additives) represent also a major source of toxicity, and some harmful compounds such as phthalate esters have been shown to accumulate in plants and generate a risk for the consumers. Adsorption of plastic particles has been evidenced for each type of photosynthetic organism, and uptake and translocation in terrestrial plants was evidenced for nanoplastics, leading to concerns for trophic chain contamination. The available techniques for the detection of microplastics and nanoplastics and their secondary products in biological samples and media are also listed. Finally, the current gaps of knowledge, specific challenges, and future research directions were also discussed.
\end{abstract}

Keywords: macrophyte, phytoplankton, plant, plastic 
35 TOC. This critical review synthesizes the knowledge acquired on photosynthetic organisms both in 36 aquatic and terrestrial compartments as well as the analytical techniques required for these studies.

37

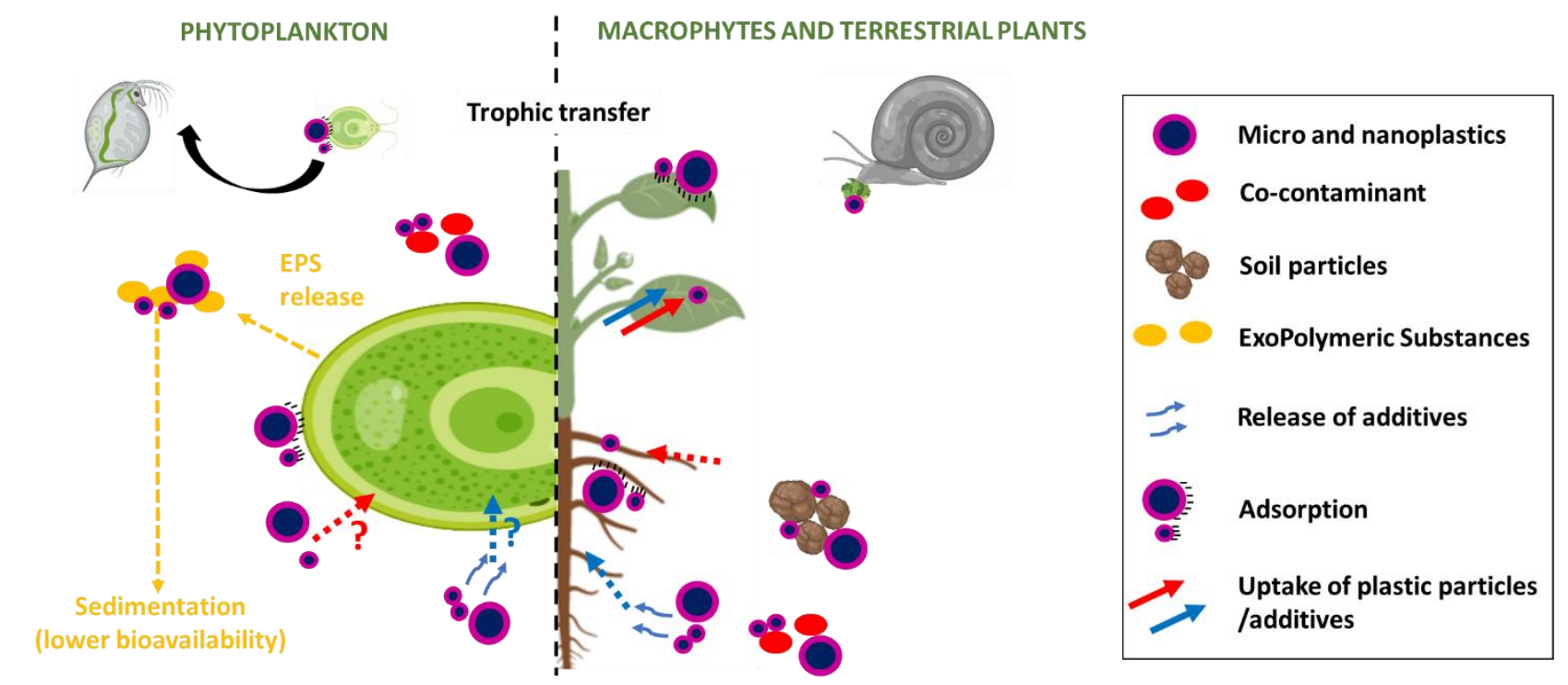


The word "plastics" gathers a wide range of synthetic polymer materials made of long organic chains deriving mainly from fossil fuel. Plastic production also implies the incorporation of additives for the processing or to improve plastic properties according to their future use; among them are catalysts, polymerization solvents, a wide range of organic and inorganic compounds, antioxidants or antimicrobials. Additives can represent up to $50 \%$ of the final material in some cases $^{1}$.

Since their discovery at the end of the $19^{\text {th }}$ century, their use in our everyday life has rapidly and exponentially increased. Indeed, the annual production went from 1.5 million tons in the 50 's to close to 335 million tons in $2016^{2}$. They are used in a wide variety of sectors such as packaging, building, transportation, renewable energy, medical devices or sport equipment ${ }^{2}$. The most commonly encountered plastics in commercial products are thermoplastics and, among those, polyethylene (PE), polypropylene (PP), polyvinyl chloride (PVC), polystyrene (PS) and polyethylene terephthalate (PET). These represent approximately 90\% of world production $^{3}$.

Unfortunately, our waste management systems are not efficiently handling plastic waste; every year only $6 \%$ at the world level is recycled and about $28 \%$ is directly disseminated in the environment, the rest being incinerated or placed in landfills ${ }^{2,4}$. Since plastics are barely degradable, they are persistent ${ }^{5}$ and are found in all environmental compartments, from mountains ${ }^{6}$ to deep sea and even in remote locations far away from any anthropogenic activities such as in the Antarctic and Artic oceans (reviewed in ${ }^{4,7}$ ). Plastic waste has been first identified and studied in oceans (mainly in ocean gyres), however some analyses revealed a similar level of contamination in continental freshwaters ${ }^{8}$ and in soils ${ }^{9}$. These plastics mainly originate from land sources $(80 \%)$ which can be as diverse as mulching in agriculture, spreading of sewage sludge or leaks from discharge sites, and transit through rivers to finally reach oceans in which they represent from 60 to $80 \%$ of the marine debris and about 10 million tons ${ }^{4,10}$. Among the most widespread plastics found in the environment are PE (about 90\%), PP and PS and mostly encountered in the form of fibers ${ }^{11}$.

In the environment, plastics undergo modifications by chemical, physical and photodegradations leading to changes in their physico-chemical properties (and possibly toxicity). For instance, one of the most common consequences of environmental weathering is the 
appearance of carbonyl functional groups leading to an overall negative surface charge of the particles ${ }^{12}$. Weathering also has consequences on particle size distribution. Indeed, in the environment several classes of plastics have been defined: macroplastics $(<1 \mathrm{~m})$, mesoplastics $(2.5 \mathrm{~cm}-5 \mathrm{~mm})$, microplastics $(1 \mu \mathrm{m}-5 \mathrm{~mm})$ and nanoplastics $(<1 \mu \mathrm{m})^{13}$. The most commonly sampled size fraction in the environment is centered around $1.5 \mathrm{~mm}^{11}$. The persistence of plastics in the environment can also lead to the adsorption of diverse biological and chemical components such as heavy metals or organic compounds (polycyclic aromatic hydrocarbons, polychlorinated biphenyls, pharmaceuticals or pesticides among others) ${ }^{14,15}$. These adsorption processes have been shown to be enhanced on weathered plastics in comparison to pristine ones ${ }^{16}$. Finally, the weathering process can also lead to the release of additives incorporated in plastics during the processing since most of them are not covalently bound to the polymer matrix and can migrate towards the surface ${ }^{17}$.

Quantifying plastics in the environment is challenging; adequate analytical techniques are being developed. Consequently, quantitative data is still scarce. Furthermore, the comparison between concentrations reported in different sites is most of the time difficult since they are presented in different units: items or mass per volume, per mass or per surface. Concentrations in soils were found ranging from 55.5 to $67500 \mathrm{mg} / \mathrm{kg}$ over different sites (reviewed in ${ }^{18}$ ). In freshwater aquatic systems, plastic concentrations also greatly vary between in average 4 items/L to as high as 25.8 items/L in Taihu lake in $\mathrm{China}^{19}$ or 419 items/L in Saigon river (Vietnam) ${ }^{20}$. Few data expressed in mass $/ \mathrm{L}$ are also available reporting concentrations from 0 to $700 \mu \mathrm{g} / \mathrm{L}$ in the Danube River ${ }^{21}$ or up to $1.56 \mathrm{mg} / \mathrm{L}$ in an urban lake in Texas ${ }^{22}$. Overall, in seawater, plastic concentrations are about 3 orders of magnitude below those found in freshwaters with average concentrations below 0.01 item/ $/ \mathrm{L}^{20}$ but could reach 1770 items/L in most polluted area such as Southern North $\mathrm{Sea}^{23}$.

The number of publications about the impact of micro and nanoplastics in the environment is rapidly increasing and good reviews have been published already on freshwater ecosystems ${ }^{4,20,24,25}$, marine ecosystems ${ }^{20,25-28}$, terrestrial ecosystems ${ }^{18,29,30}$, agroecosystems ${ }^{9}$ and on analytical methods ${ }^{31}$.

In this review, we focus on photosynthetic organisms. These organisms are of tremendous importance for ecosystem functioning since they are at the base of the trophic chains as primary producers. Here, we summarize data obtained both on aquatic (freshwater and marine) and terrestrial photosynthetic organisms to try to identify general trends. Indeed, despite the fact that these organisms thrive in different environments, they share common characteristics which 
makes the comparison relevant. For instance, they have the same autotrophic functioning unlike animals. They also possess thick cell walls which limit uptake processes. We thus detail results of micro and nanoplastic (including their leachates) uptake and toxicity to phytoplankton, macrophytes and terrestrial plants. Finally, we also develop on analytical techniques available to characterize micro and nanoplastics in such complex matrices.

\section{Phytoplankton}

If this group represents only about $1 \%$ of the photosynthetically active biomass of the world, it is responsible for about $45 \%$ of the world primary production, by fixing half of the atmospheric $\mathrm{CO}_{2}$ and about a third of "anthropogenic" carbon over the last century 32 .

Among the published papers on phytoplankton (Table 1), it is interesting to note that most of them focused on PS or PE (>75\%) and green algae and diatoms (>75\%). Microplastics are a bit more studied than nanoplastics (60\% vs. $40 \%)$ and marine environments more than freshwater systems (60 vs. 40\%). The parameters most commonly investigated were growth inhibition, photosynthetic activity and cell morphology.

\subsection{Influence of plastic particle size}

Overall, most of the studies investigated the impact of nanoplastics on phytoplankton and among them nearly $90 \%$ suggest that they have toxic effects ${ }^{33-46}$. For particles having size between 1 and $10 \mu \mathrm{m}, 90 \%$ of the concerned studies show no toxicity ${ }^{43,47-54}$. Finally, for bigger particles mostly no impact was reported or even in some cases an enhanced algal growth ${ }^{55,56}$. According to these findings, some authors suggested to introduce a threshold size for plastic ecological risk assessment and to consider particles above $100 \mu \mathrm{m}$ as low risk for microalgae ${ }^{34}$.

Some studies evidenced a size dependent toxicity of plastic particles to phytoplankton ${ }^{43,44,47,56,57}$. For instance, Li et al., exposed the microalga Chlorella pyrenoidosa (green alga) to PS particles and found $\mathrm{EC}_{50}$ of $6.9,7.2$ and $>64 \mathrm{mg} / \mathrm{L}$ for $0.1,0.55$ and $5 \mu \mathrm{m}$ particles respectively ${ }^{47}$. The same result was evidenced with the green alga Dunaliella tertiolecta $(0.05 \mu \mathrm{m} \text { PS particles were more toxic than } 0.5 \mu \mathrm{m} \text { and } 6 \mu \mathrm{m})^{43}$. This size dependent effect was also observed for PVC particles and diatoms ${ }^{44,57}$. However, few other studies show 
similar $\mathrm{EC}_{50}$ values for three green algae (Chlorella, Raphidocelis subcapitata and Scenedesmus obliquus) exposed to PS particles ranging from $55 \mathrm{~nm}$ to $2 \mu \mathrm{m}^{35,40,58}$.

$\mathrm{EC}_{50}$ reported for phytoplankton vary between 0.5 to $13 \mathrm{mg} / \mathrm{L}$ for PS nanoparticles ${ }^{33,40,47}$. The highest reported plastic concentration in the aquatic environment so far is $1.56 \mathrm{mg} / \mathrm{L}^{22}$ which suggests that plastic pollution represents a risk for phytoplankton populations in these highly contaminated area.

\subsection{Influence of plastic particle surface charge}

According to the literature, positively charged particles appear more toxic to phytoplankton than negatively charged particles ${ }^{33,39,58-60}$. Positively charged particles are usually more stable in the medium ${ }^{33}$, and are attracted by phytoplankton cell walls through electrostatic interactions, since cell wall components such as cellulose bear negative charges ${ }^{39,59}$. Negatively charged particles tend to form large agglomerates and to interact less with phytoplankton. For instance, positively charged PS nanoparticles $(50 \mathrm{~nm})$ were characterized in natural seawater with a hydrodynamic diameter $<200 \mathrm{~nm}$ and led to a decreased growth of D. tertiolecta with an $\mathrm{EC}_{50}$ of $13 \mathrm{mg} / \mathrm{L}$. On the opposite, negatively charged PS nanoparticles (40 nm) agglomerated in seawater $(>1 \mu \mathrm{m})$ and no toxicity symptom was detected up to $50 \mathrm{mg} / \mathrm{L}^{33}$. Likewise, uncharged particles tended to be more toxic than negatively charged ones with a $45 \%$ decrease in growth of the same green alga at $250 \mathrm{mg} / \mathrm{L}$ while no toxic effect was detected with the negatively charged PS particles ${ }^{43}$.

Over the different papers using functionalized particles, only one (over 8) reported toxicity of PS-COOH particles $(70 \mathrm{~nm})$ towards $S$. obliquus, however this toxicity was only visible at the highest exposure concentration: $1.1 \mathrm{~g} / \mathrm{L}$ which is extremely high ${ }^{38}$. And the only study reporting no toxicity of PS- $\mathrm{NH}_{2}$ particles to Chaetoceros neogracile (diatom) mentioned the fact that these particles once in the exposure medium had negative charges ${ }^{53}$.

\subsection{Influence of plastic particle chemical composition}


Very few articles compared the impact of plastics of different chemical nature. Some of them showed no toxicity, possibly related with the fact that they used particles with size $>100 \mu \mathrm{m}^{34,61}$. The most comprehensive study was performed by Zhu et al. and suggested that at equivalent diameter $(74 \mu \mathrm{m})$ PVC could be more toxic than PS and PE with respective algal growth reduction of $29.0 \%, 24.7 \%$, and $25.3 \%$ after $96 \mathrm{~h}$ of exposure at $100 \mathrm{mg} / \mathrm{L}^{57}$. Indeed, in the literature, PVC has been shown to be toxic in all the studies in which it has been used ${ }^{36,62}$ except when its size exceeded $100 \mu \mathrm{m}^{34}$. In contrast, the few studies done on PE and PP microplastics showed no toxicity $34,49,50,54-56,61,63$. Following a species specific distribution approach, some authors suggested that polymethylmethacrylate (PMMA) was less harmful than PS nanoparticles for marine biota ${ }^{45}$.

It seems that this difference in toxicity could be related to plastic leachate composition ${ }^{64,65}$. For instance, Capolupo et al. generated plastic leachates (PP, PET, PS, PVC, $1000 \mu \mathrm{m})^{64}$ and detected plasticizers, antioxidants, antimicrobials, lubricants, vulcanizers (between ng to hundreds of $\mu \mathrm{g} / \mathrm{L}$ ) with highest amount of additives in the PVC leachates and the least in PE leachates. Leachate composition varied according to the solution used (freshwater $v s$. seawater). This was also confirmed in another study showing the importance for leachate composition of solution $\mathrm{pH}$ and leaching time ${ }^{66,67}$. All plastic leachates, except the one derived from PET, inhibited algal growth with $\mathrm{EC}_{50}$ of $1.62 \%, 23.5 \%$ and $64 \%$ (of the initial leachate) for PVC, PS and PP, respectively.

\subsection{Influence of phytoplankton type and exposure conditions}

Several studies suggested a different sensitivity to plastics according to phytoplankton species $^{43,63,64,68}$. For instance, EC $_{50}$ have been calculated for 3 marine microalgae exposed to PMMA nanoparticles showing that the diatom species was the most sensitive $(83.4 \mathrm{mg} / \mathrm{L})$ and green alga and haptophyte had similar sensitivity (132.5 and $123.8 \mathrm{mg} / \mathrm{L}$, respectively). Sometimes this difference was related to exopolymeric substance (EPS) production ${ }^{51,68-70}$. In addition, the phytoplankton growth phase (lag, logarithmic, stationary or death phase) used for the exposure experiments can also affect the results. Some studies (less than 15\%) compared the sensitivity of phytoplankton populations when in stationary phase rather than in logarithmic growth showing a lower sensitivity ${ }^{34,35,41,51,70}$. For instance, PS nanoparticles (50 nm) decreased growth, chlorophyll concentration and increased reactive oxygen species (ROS) production of the diatom $C$. neogracile in logarithmic growth while the effect were mostly non detectable in 
stationary phase ${ }^{41}$. Authors suggested that this difference can be related with the higher EPS production by diatoms when in stationary phase that would lead to nanoplastic heteroaggregation and sedimentation decreasing plastic bioavailability in the water column. Indeed, EPS secretion has been highlighted in several studies as a way to mitigate plastic toxicity ${ }^{35,37,61,70}$ and can vary according to growth phase, algal species and the type of plastic considered $^{61,69,71}$.

During exposure, the medium composition (ions, salinity, hardness, $\mathrm{pH}$, organic matter) will also influence plastic behavior through the formation of a corona around the particles ${ }^{37,59}$ and thus influence plastic interactions with other components of the system ${ }^{53}$. For instance, the addition of humic acid $(5 \mathrm{mg} / \mathrm{L})$ in the exposure medium alleviated the toxicity of PS nanoplastics $(75 \mathrm{mg} / \mathrm{L})$ to $S$. obliquus by decreasing the adsorption of PS particles to alga surface $^{58}$.

\subsection{Cocktail effects in presence of other contaminants}

Some authors have investigated the toxicity of plastics together with other contaminants such as heavy metals $\left(\mathrm{Cu}^{37,54,62}, \mathrm{Ti}^{60}, \mathrm{Au}^{48}, \mathrm{~Pb}^{72}\right)$ or organic compounds (dibutyl phtalate ${ }^{47}$, chlorpyrifos $^{50}$, glyphosate ${ }^{73}$, phenanthrene ${ }^{34}$, $\operatorname{triclosan}^{57}$, procainamide and doxycycline ${ }^{52}$ ). Most of the time antagonistic effects were identified. Indeed, the other contaminant studied was found adsorbed at the plastic surface and thus became less bioavailable to the exposed $\operatorname{organisms}^{34,47,50,57,72,73}$. Those interactions are controlled by plastic surface charge. For instance, adding positively charged PS particles $(6 \mu \mathrm{m})$ to $\mathrm{TiO}_{2}$ nanoparticles enhanced their toxicity $(+20 \%)$ to Chlorella vulgaris (green alga) while adding negatively charged PS particles led to a decrease of about $20 \%$ in toxicity ${ }^{60}$. However, some studies reported no influence of the addition of plastics on the toxicity of co-contaminants $(\mathrm{Cu} \text { pollution })^{37,54}$. Finally, in few cases, the mixture appeared to be more toxic than the contaminants considered alone (mixture with Au nanoparticles ${ }^{48}$ or with pharmaceuticals ${ }^{52}$ ) but the lack of experimental details (plastic size or type) does not allow to go further in the explanation.

\subsection{Pristine model versus environmentally aged plastic particles}


So far studies investigating plastic toxicity to phytoplankton have mostly focused on pristine particles, predominantly PS spheres. Actual plastic debris found in the environment have a large variety of shapes (from round particles to fibers, mainly), size distribution and surface properties. In addition, these properties are supposed to evolve with the aging, which will likely result in different toxicities. So far, only one study comparing the impact of pristine plastic particles and "environmental" plastics has been published. It demonstrated that the microalga S. subspicatus was more sensitive to PE plastic coming from the North Atlantic gyre than to PE plastic made from pristine reference material ${ }^{63}$. The aged plastic contained higher concentrations of metals (Ti, Al, Fe and Zn). Likewise, C. vulgaris growth was less impacted by pristine PVC particles than by aged (2 months) PVC ones (35\% growth inhibition vs. 28\% for pristine particles $)^{62}$. FTIR showed that aged material suffered modifications of functional groups: increased in hydroxyl groups and aromatic carbon-carbon double bond but decreased carbon hydrogen bond. In another study, authors performed an accelerated aging step on PE particles by exposing them in a xenon chamber to high temperature, humidity and light irradiance conditions for up to 4 weeks ${ }^{67}$. The aging step caused surface cracks and fragmentation of the particles, increased their surface area and carbonyl contents, and promoted the release of pigments. The 4-week aged particle leachates were more toxic to cyanobacteria than the 2-week aged particle leachate and the non-aged particle leachate.

\subsection{Toxicity mechanisms}

Among the most discussed toxicity mechanisms in the literature is the particle adsorption on the surface of the organisms leading to a physical blockage of light, gases and nutrients decreasing growth and photosynthetic activity $33,35,36,39,44,60,74$. As for other carbon based nanomaterials, the involvement of shading effect has also been reported ${ }^{44}$. Beside these physical effects, some studies evidenced effects related to the chemistry of particles, inducing oxidative stress $^{42,60,62,75}$ and structural damages ${ }^{35,37,42,46,47,75}$. A recent study suggests that for the smallest particles (nanoplastics) the "chemical" effect predominates (increased ROS production, decreased photosynthesis) while for bigger particles (microplastics) toxicity is mainly driven by "physical" effects (limitation of exchanges with the medium) ${ }^{58}$. Additionally, the additives present in plastics, which can be released during aging, as well as the secondary metabolites after aging of these additives, can be responsible for the toxicity ${ }^{64,76}$. 
Very recently, few articles investigating molecular processes modified after plastic exposure were released ${ }^{75,77,78}$. Overall they confirmed the impact of plastic particles (in these cases PS) on genes involved in photosynthesis (downregulation) $)^{78}$ and in oxidative stress regulation (upregulation) $^{75}$. One of the known consequences of oxidative stress is the impairment of microtubule polymerization. Ripken et al., observed a massive upregulation in genes involved dynein-related proteins, dynein being a microtubule-associated motor protein implied in cytoskeletal dynamics suggesting that the organism was facing oxidative stress ${ }^{78}$. New findings were also suggested such as the impact on fatty acid synthesis. For instance, KCS gene expression was upregulated in Euglena gracilis possibly leading to higher extracellular secretion and hetero-aggregation phenomenon between algal cells and plastic particles ${ }^{75}$. Likewise, in Cladocopium, after PS exposure 4 genes encoding proteins found in cell surface receptors were up-regulated. These genes control cell dissociation and thus possibly influence adhesion between neighboring cells and extracellular matrix composition and could explain changes in cell aggregation ${ }^{78}$. Cell division was also impacted with a decrease in the expression of CTR1 gene related to the mitogen-activated protein kinases (MAPK) signaling pathway in E. racilis $^{75}$ and a decrease of 6 genes with RCC1 (regulator of chromosome condensation) and 3 genes with CDC domains in Cladocopium ${ }^{78}$. Finally, gene expression was altered to different extent between 2 microalgae confirming different sensitivities according to species $^{78}$.

\subsection{Accumulation and trophic transfer}

No investigation has been done so far on the potential internalization of plastic particles in phytoplankton because of the lack of adapted techniques.

However, positively charged particles tend to adsorb on phytoplankton surface. As these organisms represent the first level of trophic chains, it suggests that adsorbed plastic can be transferred to the next trophic level. This has been confirmed by few studies showing the transfer of particles from Chlamydomonas reinhardtii (green alga) to the crustacean Daphnia magna and to the fish Orizias sinensis and Zacco temminckii ${ }^{74}$. A higher toxicity of nanoPS to D. magna (6 times higher mortality) has also been evidenced when these organisms were exposed through their diet (S. obliquus exposed to nanoPS) than directly in the water column ${ }^{38}$. 

83. $\operatorname{organisms}^{88}$.

\subsection{Plastic particle degradation by phytoplankton}

If plastic can be toxic to phytoplankton, on the opposite some articles report plastics as a new opportunity for organisms as vectors for long scale traveling or as a new carbon source available for development. Analyses performed on plastic debris from the open sea have highlighted the preferential development of microbial communities on their surface, called the plastisphere ${ }^{79-}$

Since the discovery in 2016, that some bacteria (in particular Ideonella sakaiensis) are able to hydrolyze PET thanks to a specific enzyme called PETase, a lot of efforts has been put to take advantage of micro-organisms for plastic biodegradation. Microalgae seem to be a good candidate for this task through two main pathways: (i) the natural release of toxins and ligninolytic and exopolysaccharide enzymes and (ii) the synthetic production of PETase ${ }^{84}$. Indeed, cyanobacteria such as Phormidium, when growing on a low density PE film, were able to use about $4 \%$ of its carbon for their growth leading to the biodegradation of the film ${ }^{77}$. Likewise, Anabaena spiroides (cyanobacteria), Navicula pupula (diatoms) and Scenedesmus dimorphus (green algae) were able to biodegrade LDPE in their respective growth media to different extent: $8.18 \%, 4.44 \%$ and $3.74 \%$, respectively ${ }^{85}$. However, as highlighted by recent reviews ${ }^{82,83}$, biodegradation rates by microorganisms in real conditions are probably much lower than in laboratory conditions, and the nature and potential toxicity of the degradation products are still unknown.

On the other hand, some author used genetically modified microalgae to produce PETase. For instance, a lysate of modified $C$. reinhardtii incubating at $30^{\circ} \mathrm{C}$ for 4 weeks led to the apparition of dents and holes on a PET film and the detection of terephtalic acid (TPA) which is the fully degraded form of $\mathrm{PET}^{86}$. The same was also achieved by using Phaeodactylum tricornutum (diatoms) cells in growing medium under more environmentally relevant conditions ${ }^{87}$. Moreover, it has been shown thanks to a trophic chain study (bacteria, microalga, zooplankton) combined with the use of ${ }^{13} \mathrm{C}$ labeled $\mathrm{PE}$ microparticles that the plastic could be partly mineralized, used for cell growth and ${ }^{13} \mathrm{C}$ was found in cell membranes of upper trophic 
Macrophytes may be exposed to micro and nanoplastics via the aquatic medium for the shoots, and via the sediment for their root system. In this review, we have also included dead biomass of macrophytes, which plays an important role in the aquatic communities and aquatic food webs (Table 1). Only global endpoints such as biomass and pigments have been investigated so far, on a limited number of organisms, and for a limited type of plastic particles.

\subsection{Plastic particle toxicity}

Kalcikova et al. evaluated the effect of PE microplastics from cosmetic products on duckweed $(\text { Lemna minor })^{89}$. Specific leaf growth rate and concentration of photosynthetic pigments in duckweed leaves were not affected, whereas root growth was significantly decreased with 50 $\mathrm{mg} / \mathrm{L}$ PE microbeads; the authors suggested that this could be due to mechanical blocking. Surface properties seemed to influence microplastic toxicity. Indeed, sharp particles reduced the viability of root cells, while the impact of microplastics with a smooth surface was negligeable. The same group showed that microplastics incubated in wastewater at different organic loads had different toxicity to $L$. minor ${ }^{90}$. Van Weert et al. evaluated the impacts of PS nanoplastics (50-190 $\mathrm{nm}$ ) and microplastics (20-500 $\mu \mathrm{m})$ on the macrophytes Myriophyllum spicatum and Elodea sp., after exposure to plastic amended sediment ${ }^{91}$. Microplastics did not produce consistent dose-effect relationships, and nanoplastics significantly induced an increased root biomass compared to shoot biomass of M. spicatum. For Elodea sp., the biomass and growth parameters tested were positively correlated to nanoplastic concentration.

\subsection{Accumulation and trophic transfer}

Published data concerns microplastics only. Some lab-based experiments investigated the sorption of microplastics on macrophytes. Sundbaek et al. evaluated the adsorption of fluorescent PS microplastics of $20 \mu \mathrm{m}$ diameter on the surface of the macroalga Fucus vesiculosus $^{92}$. After $2 \mathrm{~h}$ in filtrated seawater containing $2.65 \mathrm{mg} / \mathrm{L}$ microplastics (corresponding to 597 items $/ \mathrm{mL}$ ), the algal surface contained on average 3.99 items $/ \mathrm{mm}^{2}$ (corresponding to 2787 items/g dry weight DW), but only 0.22 item $/ \mathrm{mm}^{2}$ after washing in filtrated seawater. Gutow et al. did the same kind of experiment at lower concentrations of PS (1.4 to 55.7 items of $10 \mu \mathrm{m}$ diameter per $\mathrm{mL}$ ), and also observed a sorption to the surface of $F$. vesiculosus, with 
an average of 0.04 item $/ \mathrm{mm}^{2}$ after washing for the highest concentration ${ }^{93}$. Similarly, MateosCardenas et al. showed that 10-45 $\mu \mathrm{m}$ PE microplastics can strongly adsorb to all surfaces of L. minor, although photosynthetic efficiency and plant growth were not affected by microplastics ${ }^{94}$. To our knowledge, there is no data on the transfer of micro or nanoplastics from the surface of macrophytes to the inside of plant tissues. Likewise, the possible uptake of plastic particles from the sediment to the root system of macrophytes is not yet documented. Beside these laboratory studies, the presence of microplastics on macrophytes collected in natural environment was investigated. Goss et al. showed that $75 \%$ of marine turtle seegrass (Thalassia testudinum) collected from an area impacted by urban discharges had encrusted microplastics ${ }^{95}$. Microfibers, beads, and other microplastic fragments were found adhered to seagrass blade surfaces, often overgrown by periphyton and various epibiont organisms. This suggests that these macrophytes may represent a pathway for plastics into marine food web. Saley et al. found $8.65 \pm 6.44$ and $2.34 \pm 2.19$ items/g on the surface of the marine macrophytes Endocladia muricata and Pelvetiopsis limitata growing in a remote marine reserve on the open coast of California ${ }^{96}$. Densities were higher in the herbivorous snail, Tegula funebralis, at 9.91 \pm 6.31 items $/ g$, potentially due to bioaccumulation ${ }^{96}$.

Posidonia oceanica is a macrophyte endemic of the Mediterranean sea, considered a key species because it serves as habitat and food source for many marine organisms. Egagropiles, which are spheroids made of dead biomass of $P$. oceanica, ubiquitous in the Mediterranean coastal zone, also constitute a habitat and food source for the fauna and microfauna of sandy beaches. Pietrelli et al. showed that $53 \%$ of these spheroids contained plastics ${ }^{97}$. These plastic particles may have sorbed to the leaf blades during plant growth and also after their death. Remy et al. found that $27.6 \%$ of the digestive tracts of detritivorous invertebrates feeding on dead biomass of $P$. oceanica, collected in a Mediterranean coastal zone, contained plastic fibers of various sizes $^{98}$.

To our knowledge, there is no study on the biodegradation of micro or nanoplastics by macrophytes.

\section{Terrestrial plants}


One of the main identified routes for the entry of plastics into soils is the use of plastic mulch in agriculture 9 . Hegan et al. simulated the accumulation of plastic residues after repeated field mulching and they found that, after 121 years, the cumulative reduction yield per surface area would be greater than the benefit of using the mulching ${ }^{99}$. Traditional polymers used for this purpose were low and high density PE (LDPE, HDPE) but in recent years, different biodegradable polymers such as polylactic acid (PLA), poly-hydroxyalkanoate (PHA) or cellulosic and starch based polymers are being tested. Besides, plastic residues from consumer products arrive to soils through the application of sewage sludge as fertilizer and, to a lesser extent, from atmospheric deposition, runoff from aquatic bodies and polymer seed coating ${ }^{100}$. Urban soils can also present plastic pollution due to the release of fragments or leachates from plastics used in outdoor applications ${ }^{101}$.

There is still a limited number of studies addressing the effects of micro and nanoplastics in terrestrial plants (17 studies, Table 1), most of them focused on crops (13 studies) and PS particles (11 studies). Overall, studies regarding the impacts of microplastics (10 studies) are performed in quite similar experimental conditions: pot experiments, long exposures ( 1 to 5 months), and similar plastic concentrations $(0.001-2 \% \mathrm{w} / \mathrm{w})$. The main parameters studied are germination, plant growth and photosynthesis. In the case of nanoplastics (10 studies), all available studies were performed in soil free media. Besides parameters considered for microplastics, these studies also included cyto- and genotoxicity, oxidative stress, genomics and metabolomics studies.

\subsection{Influence of plastic particle size, shape and surface charge}

Only three studies have addressed the size dependent toxicity of plastic particles in plants. In a pot experiment, Qi et al. ${ }^{102}$ found that microparticles (50 $\mu \mathrm{m}$ to $1 \mathrm{~mm}$ ) of LDPE and starch based biodegradable plastic produced slightly more negative effects on root and total biomass of wheat plants than macroplastics ( 7 x $1.5 \mathrm{~mm}$ average) of the same polymers. A size and dose dependent delay in germination was observed in Lepidium sativum exposed to 50, 500 and 4800 $\mathrm{nm}$ fluorescent PS particles ${ }^{103}$. It was stronger for the biggest particles, which accumulated in seed testa probably blocking water uptake. Seedlings $72 \mathrm{~h}$ after germination showed decreased root growth for $50 \mathrm{~nm}$ particles treatment but the opposite in $500 \mathrm{~nm}$ treatment. In another study, seedlings of Vicia faba (36-48h after germination) were exposed to $5 \mu \mathrm{m}$ and $100 \mathrm{~nm}$ PS fluorescent particles at $0,10,50$, and $100 \mathrm{mg} / \mathrm{L}$ for $48 \mathrm{~h}^{104}$. In this study, root biomass and length were more decreased by microparticles while oxidative stress measured as malondialdehyde 
(MDA) and micronucleus frequency were mostly affected in nanoparticle treatments. Laser confocal microscopy showed larger number of particles accumulated in the root tips of plants exposed to $100 \mathrm{mg} / \mathrm{L}$ nanoparticles than in the same dose of microparticles.

Some studies also pointed to the shape, as one of the variables controlling plastic toxicity. Synthetic microsized fibres (mixture of nylon and acrylic) induced similar effects on the germination rate, shoot length and chloropyll a/chloropyll b ratios of Lolium perenne than HDPE and PLA microparticles, even when applied at hundred times lower concentration $(0.001 \% \text { vs. } 0.1 \%)^{105}$.

In another study, Allium fistulosum was exposed to polyester (PES) fibres $(0.2 \% \mathrm{w} / \mathrm{w})$, PA beads and microparticles of HDPE, PP, PS and PET (2\% w/w) for two months ${ }^{106}$. PES fibres induced the strongest effects on studied plants traits.

To date, only one study has addressed the influence of particle charge on plastic toxicity to terrestrial plants. Positively charged PS- $\mathrm{NH}_{2}$ nanoplastic were more toxic to Arabidopsis thaliana than negatively charged $\mathrm{PS}-\mathrm{SO}_{3} \mathrm{H}$ nanoplastics, although the uptake was higher in the latter $^{107}$.

\subsection{Influence of plastic particle chemical composition}

Qi et al. found that the biodegradable starch-based plastic induced stronger negative effects on wheat than $\mathrm{LDPE}^{102}$. This was attributed to the components (37.1\% pullulan, $44.6 \%$ PET and $18.3 \%$ polybutylene terephthalate (PBT)) of the biodegradable plastic that may be more toxic than LDPE. The authors observed important changes in chemical and bacterial composition of the rhizosphere in soils spiked with starch based plastic that may explain, at least in part, observed effect on wheat plants ${ }^{108}$.

Microparticles of PLA, were shown to be more toxic to L. perenne than microparticles of HDPE with similar size at the same concentration ${ }^{105}$. PLA decreased germination rate by $7 \%$ and decreased shoot length after 30 days whereas the exposure to HDPE increased root biomass. In another study, PA beads induced higher effects than the microparticles of PEHD, PP, PS and $\mathrm{PET}^{106}$. According to the authors, the lower toxicity induced by PEHD, PET, PP and PS microparticles could be explained because they were mainly composed by $\mathrm{H}$ and $\mathrm{C}$, whereas PA beads contained $\mathrm{N}$ and additives that can alter soil chemistry. 
Other studies have shown that leachates derived from plastic degradation may contain polymer monomers and/or additives that can cause toxicity to plants. For instance, genotoxicity and cytotoxicity were induced in A. cepa exposed to leachates from the composting of a new biodegradable nanocomposite of PLA and nanoclays ${ }^{109}$. Leachates from HDPE and compostable plastic bags delayed and advanced the germination of the coastal dune species Thinopyrum junceum and Glaucium flavum, respectively ${ }^{110}$. However, no negative effect has been found in Brassica rapa var. chinensis exposed to the biodegradation products of PBAT (butylene adipate-coterephthalate) $^{111}$.

\subsection{Cocktail effects in presence of other contaminants}

Only two studies have explored the combined toxicity of plastics with other pollutants in terrestrial plants, both in hydroponics conditions. Dong et al. investigated the phytotoxicity of PS and PTFE microparticles alone or in combination with As(III) over a range of concentrations (0.004-0.2 mg/L plastics, 0.04-4 mg/L As(III)) for rice plants ${ }^{112}$. Lian et al. investigated the impact of PS nanoparticles $(0,10 \mathrm{mg} / \mathrm{L})$ on the toxicity of $\mathrm{Cd}(0,20 \mu \mathrm{M})$ in wheat ${ }^{113}$. In both cases, although the exposure to plastic particles alone caused negative effects on plants, their combined exposure with As and $\mathrm{Cd}$ were less toxic than the exposure to $\mathrm{As}$ and $\mathrm{Cd}$ alone. The alleviation of toxicity by plastic particles was mainly explained by the adsorption of the pollutant to plastic surface that reduced total concentrations in plants. The reduction of root activity caused by plastics may also decrease the uptake of As and Cd.

Besides this, PS nanoparticles increased the concentration of carbohydrates which may trap free radicals reducing $\mathrm{Cd}$ toxicity to wheat ${ }^{113}$.

\subsection{Toxicity mechanisms}

Phytotoxicity caused by plastic seems to depend on a wide range of variables including polymer type, presence of additives, size, shape, surface charge of plastics and dose.

Mechanisms underlying observed effects on plants can be indirect through changes in the physical environment of soils which include alterations in the profile of water-stable aggregates $^{105}$, soil bulk density, soil aggregation and water cycling ${ }^{106}$. Atuanya et al. already 
suggested that the reduction of growth found in Zea mays plants grown in soils containing 2.5\% w/w of PE granules was related to an increase in the bulk density of the soil ${ }^{114}$. However, only van Kleunen et al. have used cork microparticles as additional control to test the hypothesis of changes in soil structure as the cause of microparticle toxicity ${ }^{101}$, and suggested, contrary to Atuanya et al., that particles improved the drainage or aeration of the soil. Cork granules showed less negative effects than ethylene propylene diene monomer (EPDM) particle on Plantago lanceolate ${ }^{101}$, which makes it necessary to reconsider the results from the previous studies that did not use this kind of control. The phytotoxicity of plastic residues have also been attributed to a direct chemical toxicity due to the leaching of polymers or additives ${ }^{105,108-110}$. But none of these studies have quantified the release of additives. Qi et al. ${ }^{108}$ and De Souza Machado et al. ${ }^{106}$ also suggested that the presence of plastics in soil can alter C:N ratios, thus affecting nutrient balance for plants. These physical or chemical changes in the soil can also affect soil biota (earthworms ${ }^{102,105}$, soil microbial community ${ }^{106,108}$ ) indirectly affecting plant development.

Microscopic observations of particle accumulation in seed and root surfaces suggested that the inhibition of water and nutrient uptake was one of the main mechanism altering germination and plant development ${ }^{104,115,116,103}$. However, this hypothesis was not verified by nutrient or water content measurements. On the opposite, Lian et al. found an increase of seed vigour and seedling length in wheat seeds exposed to PS nanoparticles that was accompanied by an increase in water uptake ${ }^{117}$. And, Taylor et al. found the accumulation of micro and nano spheres of PS in the root cap of Arabidopsis thaliana and T. aestivum, but no evidence of uptake or negative effects ${ }^{118}$.

Dose-dependent decreases in mitotic index have been reported in A. cepa $a^{115,119}$ and in $V$. faba $a^{104}$ seedlings exposed to PS nanoparticles. In the case of $A$. серa, the presence of nanoplastics inside cells interfering with some organelles was reported for the first time. The presence of lipid bodies in the cytoplasm of exposed plants revealed some alterations in lipid mobilization. Non monotonic oxidative stress was also reported for these two species suggesting that antioxidant systems in plants may prevent lipid peroxidation to a certain dose of nanoplastics and that other toxicity mechanisms may trigger observed cyto and genotoxicity. Wheat plants exposed to PS nanoparticles for three weeks showed lower contents of the non-enzymatic antioxidants proline, glycine and glutamine than the controls ${ }^{117}$. Lian et al. have suggested that PS nanoparticles can reduce the concentration of free radicals reducing oxidative stress in wheat ${ }^{113}$. In both studies, 
metabolomics analysis revealed an acceleration of carbohydrate and aminoacid metabolism which can be a mechanism to cope with PS toxicity. However, Sun et al. found ROS production and inferences in the regulation of genes related with oxidative stress in A. thaliana exposed to PS nanoparticles ${ }^{107}$.

Finally, nutrient imbalances, changes in root morphology and alterations in shoot to root ratio have been reported ${ }^{106,113,117}$.

\subsection{Accumulation and trophic transfer}

To date there is no information about the uptake of microparticles by plants and their potential trophic transfer. Due to their small size, nanoplastics are more likely to be taken up by plants and transported to the edible parts. The use of fluorescent PS nanoparticles have allowed to show the absorption of nanoplastics by the roots of L. sativum ${ }^{103}$, V. faba $^{104}$ and A. cepa $a^{115}$ and the translocation to the shoots of T. aestivum ${ }^{117}$. By combining two photon excitation and time resolved (TPE-TR) optical imaging, fluorescence lifetime imaging (FLIM) microscopy and transmission electron microscopy (TEM), Zhang et al. showed the uptake and translocation of styrene maleic anhydride nanoplastics (SMA-PNPs) in Murraya exotica ${ }^{120}$. A recent article just reported the trophic transfer of PS fluorescent nanoplastics from soils $(100 \mathrm{mg} / \mathrm{kg})$ to mung beans and then to African giant snails ${ }^{121}$. These studies provide significant evidence of nanoplastic uptake by plants. However, they did not provide quantitative information and they used only model nanoplastics in quite unrealistic exposure conditions. This information does not allow yet to assess the risk of transfer of plastic particles from terrestrial plants to the food chain.

Still, pot studies ${ }^{122}$ and survey of commercialized vegetables from greenhouses ${ }^{123,124}$ showed that vegetables and cereals accumulate high amounts of phthalates, leading to a high risk of trophic transfer of these additives through the diet ${ }^{123}$.

\subsection{Plastic particle degradation in the rhizosphere}

The rhizosphere being a zone of intense bacterial and fungal activity, and some strains having been shown to degrade plastics, a few studies examined the fate of plastics in the rhizosphere. To our knowledge, the biodegradation of nano and micro-plastics in the rhizosphere has not been studied so far. Two studies investigated the degradation of macroplastics in the rhizosphere of plants, or in contact with rhizosphere fungi or bacteria. One study showed a loss 
of weight for biodegradable PLA, not for PET ${ }^{125}$, and the second one showed changes in physical and chemical properties of PE strips, but non reproducible losses of weight ${ }^{126}$.

5. Methods for detection and characterization of micro and nanoplastics in photosynthetic organisms

The widespread environmental presence of micro and nanoplastics and the potential adverse effects to photosynthetic organisms demand the development of adapted detection and characterization techniques that provide access to their chemical nature, shape and size, surface chemistry, dissolved fraction and leachate composition. In particular, for nanoplastics methodological challenges are associated with detection and recovery of these carbon-based materials in complex natural matrices (such as photosynthetic organisms). Among a variety of analytical methods to characterize plastic contaminants in ecotoxicology, the techniques described below are the most widely used to detect and characterize their changes in chemistry and morphology before or after interactions with photosynthetic organisms. Figure 1 presents a summary of the main sample preparation steps and information obtained from these techniques techniques and more details are provided in Table 2.

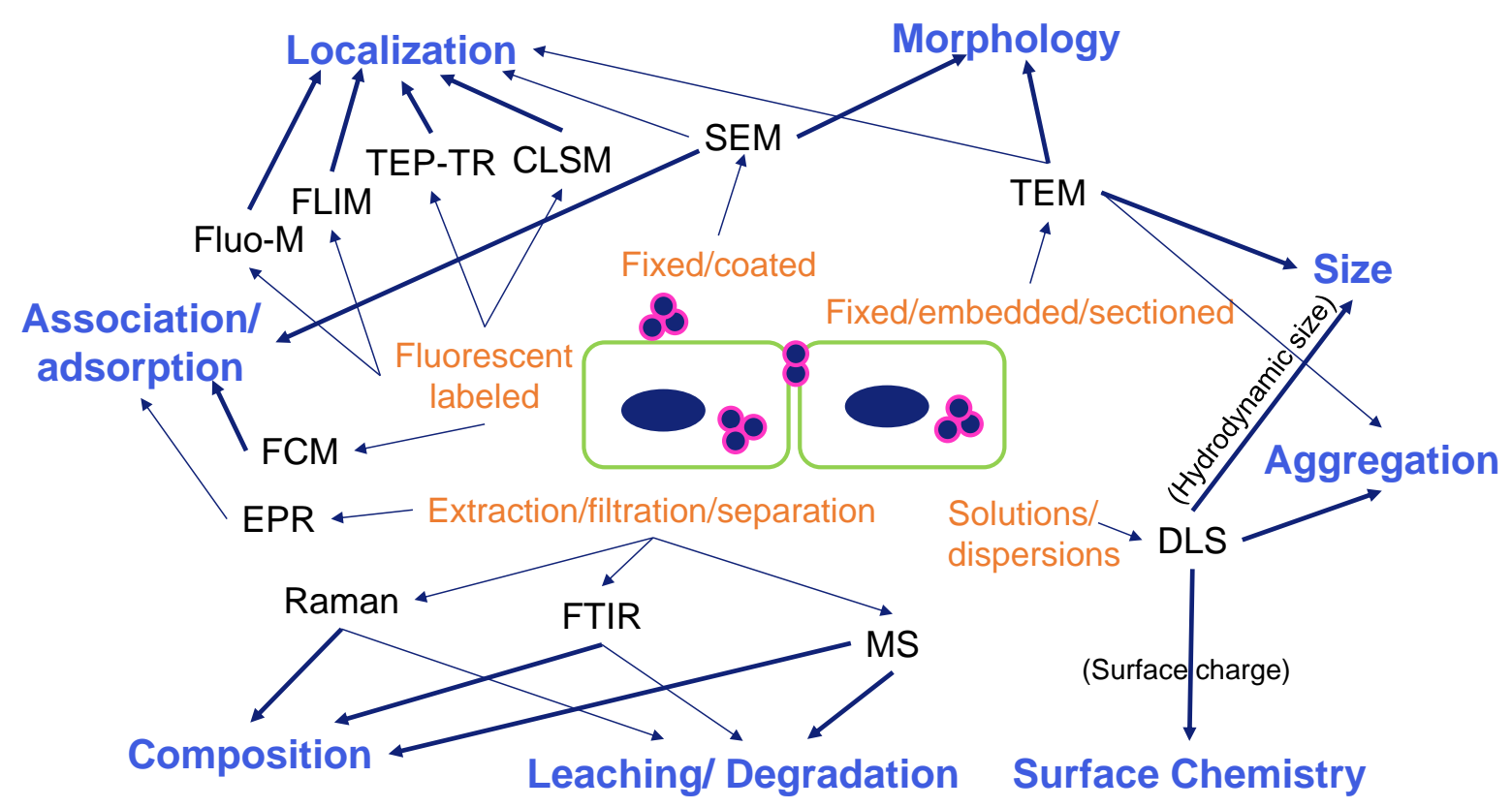

Figure 1. Analytical techniques used for detection and characterization of micro and nanoplastics in photosynthetic organisms. In green (general) sample preparation requirements, in blue the characterization properties obtained (darker arrows are indicative of the main use of the technique). 
Acronyms: confocal laser scanning microscopy (CLSM), electron paramagnetic resonance (EPR), flow cytometry (FCM), fluorescence lifetime imaging (FLIM), fluorescence microscopy (Fluo-M), mass spectrometry based techniques (MS), scanning electron microscopy (SEM), transmission electron microscopy (TEM), two-photon excitation and time resolved detection imaging (TPE-TR), dynamic and electrophoretic light scattering (DLS), Raman (micro)spectroscopy (Raman), Fourier transform infrared (micro)spectroscopy (FTIR).

\subsection{Microscopy}

The use of microscopy techniques in different modalities is one of the recurrent methods for plastic identification from environmental samples and is often followed by chemical identification by means of vibrational spectroscopy or mass spectrometry techniques. In ecotoxicological studies of micro and nano plastics in photosynthetic organisms, a variety of microscopic methods have been used and are below divided in electron, fluorescence, and laser based methods.

\subsubsection{Electron based microscopy}

High resolution images can be obtained using electron based methods in both scanning (SEM) and transmission (TEM) modes. These methods are often used before interaction with organisms in order to characterize size and morphology of micron and nano size plastics. Electron microscopy applications in the characterization of plastic interactions with organisms demands careful sample preparation protocols (dehydration, fixation, staining, coating) and the contrast offered by plastics does not allow unambiguous identification. In order to gain additional information, for example to discriminate plastic from inorganic particles, the use of energy dispersive X-ray fluorescence detection is advised. Despite of this fact, electron based microscopy has been widely used to characterize associations of micro and nanoplastics with phytoplankton $33,35,36,38,39,41,42,44,53,57,60,62,69,70,73,74,81$ with a predominant use of SEM. In terrestrial plants, evidence of cell internalization in A. cepa exposed to nanoPS has been obtained from transmission electron microscopy images ${ }^{115}$. 


\subsubsection{Fluorescence microscopy}

This microscopy method has been used to determine the interaction of micro and nanoplastics with photosynthetic organisms and in particular has provided evidence of aggregation with phytoplankton $33,34,37,56,69,70,74$ and internalization of micro ${ }^{103}$ and nano ${ }^{107,115}$ plastics in terrestrial plants. This is of outmost relevance to evaluate uptake mechanisms and to perform risk analysis of food chain transfer in the environment through primary producers. However, this method can only be applied on model fluorescent plastic materials and do not fully represent the myriad of shapes, surface properties and sizes found in the environment. For this reason and, due to the importance of environmental weathering in determining the fate of plastic in the environment ${ }^{4,100}$, results from this technique require careful interpretation when extrapolated to real environmental plastic pollution scenarios.

Staining dyes (Oil red EGN, Eosin B, Hostasol Yellow 3G, Nile red and Rose Bengal) could be used in staining protocols after exposure, the issue is that the affinity of these dyes for plastics $v s$. biogenic material would complicate interpretation. Hence, existing protocols require digestion, extraction, or filtration steps to remove biogenic material. These protocols may be used for testing plastic presence in photosynthetic organisms from environmental samples ${ }^{127}$. However, this approach does not allow for precise cellular and tissue localization.

\subsubsection{Laser scanning microscopy}

Confocal laser scanning microscopy (CLSM) allows direct and non-invasive serial optical sectioning of intact living photosynthetic organisms. This method requires minimum sample preparation. However, as in the case of fluorescence microscopy, specimens are treated with fluorescent dyes to make selected objects, in this case plastics, visible. By performing successive slices (z-stack) images can be arranged to create a 3D image. Their application in studying photosynthetic organisms is advantageous but careful selection of the excitation/emission wavelength of the labelled plastic material should be done in order to prevent autofluorescence from the specimen to mask its signal. In plant leaves, the primary contributor of autofluorescence is chlorophyll, but lignins, carotenes, and xanthophylls also produce a significant level of fluorescence emission. This technique has been used to investigate nanoplastic association with microalgae $e^{42,53,60,62,69,70,74}$. In terrestrial plants, with aid of CLSM the presence of microplastics in the seed capsules, and at later stage in the root hairs of $L$. 
sativum was identified ${ }^{103}$. In V. faba, $100 \mathrm{~nm}$ PS particles were observed entering the roots ${ }^{104}$ and in T. aestivum CLSM demonstrated uptake of PS nanoparticles in roots ${ }^{117}$. Other techniques based on laser scanning are two-photon excitation and time-resolved detection (TPE-TR) and fluorescence lifetime imaging (FLIM). Zhang et al. used TPE-TR as a noninvasive approach to investigate kinetics and uptake mechanisms of Eu luminescent styreneco-maleic anhydride SMA-NPs in $M$. exotica ${ }^{120}$. This novel approach exploits the differential fluorescence persistence of the Eu luminescence and the autofluorescence of plant tissues $(\sim 1$ ms vs. $<100 \mathrm{~ns}$ ) to set an appropriate time delay prior to Eu luminescence detection to avoid interference from autofluorescence. It offers the advantage of wide field of view $\left(32 \times 32 \mathrm{~mm}^{2}\right)$ and large imaging depth that enables in vivo analysis in plants and other organisms. However, the resolution obtained is $60 \mu \mathrm{m}$, for high resolution studies and for a more detailed localization FLIM can be used in combination. Similarly, FLIM takes advantage of the longer fluorescence lifetime of the Eu-luminescent nanoplastics to eliminate autofluorescence interference; the resolution is sub-micrometric ${ }^{128}$. Results from this study revealed inter cell wall deposition of SMA-NPs in the lignified epidermis of $M$. exotica plants that represents a path of uptake and translocation, and revealed similar accumulation kinetics at different positions along the plant stems ${ }^{120}$. Efforts should be made to produce luminescent plastic particles with characteristics similar to those found in the environment. It is worth noting that the use of lanthanide doped or metal doped particles would enable detection of these materials in complex biological systems through the use of element sensitive techniques (bulk and microscopy) typically used for metal engineered nanoparticles ${ }^{129,130}$. For instance, PS-Pd nanoplastic have been recently used to confirm the internalization of PS nanoplastics by A. thaliana ${ }^{107}$.

\subsection{Flow cytometry}

An additional method that can be successfully coupled to laser induced fluorescence (natural or following staining) is flow cytometry (FCM). However, this method is a bulk technique and no spatial information is obtained. This technique screens a sample containing cells or particles suspended in a fluid and flows one cell at a time through a laser beam. FCM is able to analyse quickly and simultaneously large quantities of cells in suspension and several parameters (cell characteristics and function, plastic association with cells). MicroPS were quantified using FCM in microalgal cultures and allowed the distinction between free suspended micro-PS, 
696

hetero-aggregates, and microalgae ${ }^{51}$. These results underline the potential interactions of phytoplankton cell and residual organic matter with microplastics and their influence on bioavailability in aquatic systems.

\subsection{Vibrational (micro)spectroscopy}

Detailed chemical information about plastic materials can be obtained from vibrational spectroscopy methods. Fourier transformed infrared (FTIR) and Raman spectroscopy being the most popular methods and offering complementary information. Moreover, both methods can be coupled to a microscope offering spatially resolved chemical composition. These techniques can provide insight about the chemical changes in the plastic material induced by aging in the environment $^{62,67,81}$. Though direct analysis (in situ) in photosynthetic organisms by these techniques, in micro-spectroscopy mode, is in principle feasible, this has not been attempted yet (to the best of our knowledge) and limitations exist due to spatial resolution or sample preparation.

FTIR produces a molecular fingerprint resulting from the change in dipole moment of chemical bonds, and allows the detection of various types of plastics such as PS or PE due to characteristic bands ${ }^{116}$. The commonly used analytical modes are transmission, attenuated total reflection and reflectance. The three modes may be used in combination with a microscope and the spatial resolution is around $10 \mu \mathrm{m}$ for bench-top instrument with a globar source (but it may reach the diffraction limit if a synchrotron source is used) ${ }^{132}$. Though the direct detection of plastic materials may be challenging, FTIR micro-spectroscopy may be used to assess biomolecular changes in aquatic and terrestrial plants induced by exposure to these materials. Resolution of FTIR micro-spectroscopy can reach nanoscale when coupled to an atomic force microscopy tip (in thermal expansion or near-field mode) but this significantly complicates sample preparation protocols ${ }^{132}$.

Raman provides a molecular fingerprint spectrum based on the polarizability of chemical bonds ${ }^{131}$. Raman microscopy allows the characterization of microplastics down to $300 \mathrm{~nm}$, in some cases it can provide additional information about contained fillers and pigments, and it does not suffer from water interference. However, some drawbacks are the weak nature of the signals (approx. $10^{-8}$ photons reaching the sample produce Raman signal), increasing 
measurement duration, and interference from sample autofluorescence, that depend on the organism and the plastic material characteristics such as color, biofouling and degradation ${ }^{133}$.

\subsection{Dynamic light scattering (DLS)}

DLS is currently the most widely used technique for the characterization of micro and nanoplastic (size range from $0.7 \mathrm{~nm}-10 \mu \mathrm{m}$ ) hydrodynamic diameter ${ }^{134}$. This technique offers affordability and easy usage with built-in automatized data analysis, but it has some limitations: (i) it is a blind technique, so it can be used only on nanoplastic suspensions in water or in nutrient solutions devoid of other types of particles, and (ii) it does not provide reliable results for polydispersed suspensions (containing various particle size categories). The hydrodynamic diameter is hence the most commonly reported parameter since it reflects the size of the particle in suspension and includes coatings or surface modifications. The available instruments for DLS offer also the capability to determine the electrophoretic movement of the particles when applying an electric field, this allows to calculate the zeta potential value of the particles, i.e. the surface charge of particles. This is a key indicator of the stability of the colloidal dispersion; its magnitude denotes the degree of electrostatic repulsion between adjacent similarly charged particles in the dispersion. This technique has been applied as routine in most of the research work included in this review (60\% of the cited studies), in most cases for characterization of the hydrodynamic size of the particles in different growth and exposure media.

\subsection{Magnetic based}

Electron paramagnetic resonance (EPR) spectroscopy is a technique used for the characterization of paramagnetic compounds. Paramagnetic compounds and atoms are characterized by the presence of unpaired electrons, EPR spectroscopy measures electron spin transitions in molecules in the presence of an external magnetic field ${ }^{135}$. This technique allows to study for example the formation of environmentally persistent free radicals and oxygen free radicals formed on the surface of microplastics when exposed to sunlight ${ }^{136}$. In the study of Casabianca et al., EPR was used to investigate the associations of marine phytoplankton and PET plastics in seawater ${ }^{68}$. In this study a paramagnetic surfactant dodecyldimethylammonium- 
2,2,6,6-tetramethyl-piperidine-N-oxide bromide (CAT12) with good affinity for insertion into the cell membrane was used to probe cell-plastic affinity ${ }^{68}$. The diatom S. marinoi presented an exponentially increasing adsorption to PET as a function of incubation time. On the other hand, L. polyedrum showed lower adsorption and a different mechanism of interaction with the plastic surface. This demonstrates the applicability of this technique to obtain useful information about the mechanisms of adhesion of microalgae in plastic surfaces.

\subsection{Mass spectrometry based techniques}

Mass spectrometry (MS) based techniques measure the mass-to-charge ratio of ions. The most commonly used separation methods are gas chromatography (GC) and (high performance) liquid chromatography (HPLC/LC). These methods have the advantage of being able to provide chemical composition of plastic materials from relatively high mass and representative samples, but the down side is that they are destructive $\mathrm{e}^{25}$.

In Chae et al. the leachates from micro-sized PE spheres in algal growth medium were analyzed qualitatively by HPLC-MS ${ }^{56}$. The results reported the presence of bisphenol A, phthalates, dibutyl phthalate, and UV stabilizers (such as octyl methoxycinnamate) in the medium. Another study by Tetu et al. in Prochlorococcus photosynthetic bacteria ${ }^{65}$ found that leachates from HDPE and PVC contained 5877 and 10658 components, respectively. This was a broad chemical screening that did not allow identification of individual chemical species. This study also demonstrated the enrichment of elements such as $\mathrm{Zn}, \mathrm{Sr}$ and $\mathrm{Cu}$ through the use of inductively coupled plasma (ICP-MS).

Similarly, Capolupo et al. used a combination of GC-MS and ICP-MS to screen the organic and inorganic composition of fresh and marine water leachates produced by car rubber tire, PP, PET, PS and PVC microplastics ${ }^{64}$. This analysis revealed the presence of additives (benzothiazole, phtalide, acetophenone) and metals ( $\mathrm{Co}, \mathrm{Zn}$ and $\mathrm{Pb}$ ) with concentrations varying depending on the plastic type. Thermal decomposition and extraction variants of GCMS exist such as pyrolysis-GC-MS and thermo extraction and desorption (TED-GC-MS). In pyro-GC-MS microplastics are thermally decomposed (pyrolyzed) and the gas formed is cryo trapped and separated on a chromatographic column, this method has been successfully used to identify polymer types and additives in marine microplastics ${ }^{137}$. However, it was unsuccessful 
to detect PS in the roots of $A$. thaliana and $T$. aestivum because of the interference with styrene peak, which can be a degradation product of the pyrolysis of plant tissues ${ }^{118}$. TED-GC-MS combines thermo gravimetric analysis for thermal degradation and solid phase extraction for identification of plastics in environmental samples ${ }^{138}$.

Recently, Bolea-Fernandez et al. presented a new approach based on ICP-MS detection operated in single-event mode or single particle (SP) ICP-MS mode ${ }^{139}$. This method relies on ultra-fast monitoring of the signal intensity spikes for the mass-to-charge ratio of $\mathrm{C}^{13+}$ produced by individual particles. The method was demonstrated with PS microspheres (1-2.5 $\mu \mathrm{m})$ and allows for quantitative determination of mass concentration and size distribution. This is a very promising method that requires further optimization to be routinely used in environmental samples such as photosynthetic organisms. In fact, for all mass spectrometry based techniques the feasibility to apply them to plastic materials interacting or internalized in photosynthetic organisms requires more study to develop adequate sample preparation protocols.

\section{Conclusions, knowledge gaps and future directions}

Figure 2 provides a synthesis of the current knowledge on the fate and effects of micro and nanoplastics on photosynthetic organisms. The overview of the literature shows that plastics have significant impacts on photosynthetic organisms. There are comparatively much less studies on terrestrial crop plants than on aquatic organisms, although micro and nanoplastics are ubiquitous in agricultural soils. The observed effects seem to be modulated by particle size, surface charge, composition and shape of the particles, as well as their agglomeration and weathering state. The impact of these parameters have been investigated more in depth in phytoplankton and results show that overall nanoplastics $(<1 \mu \mathrm{m})$ are more toxic, especially those bearing positive surface charges, with $\mathrm{EC}_{50}$ between 0.5 to $13 \mathrm{mg} / \mathrm{L}$ for PS nanoparticles. PVC and PS particles tend to be the most toxic while PE and PMMA have less effects on phytoplankton. The effects of biodegradable plastics have been studied in soils and they can induce similar or even more phytotoxicity than classical polymers. Bigger plastic particles (> $100 \mu \mathrm{m})$ showed little effect. 


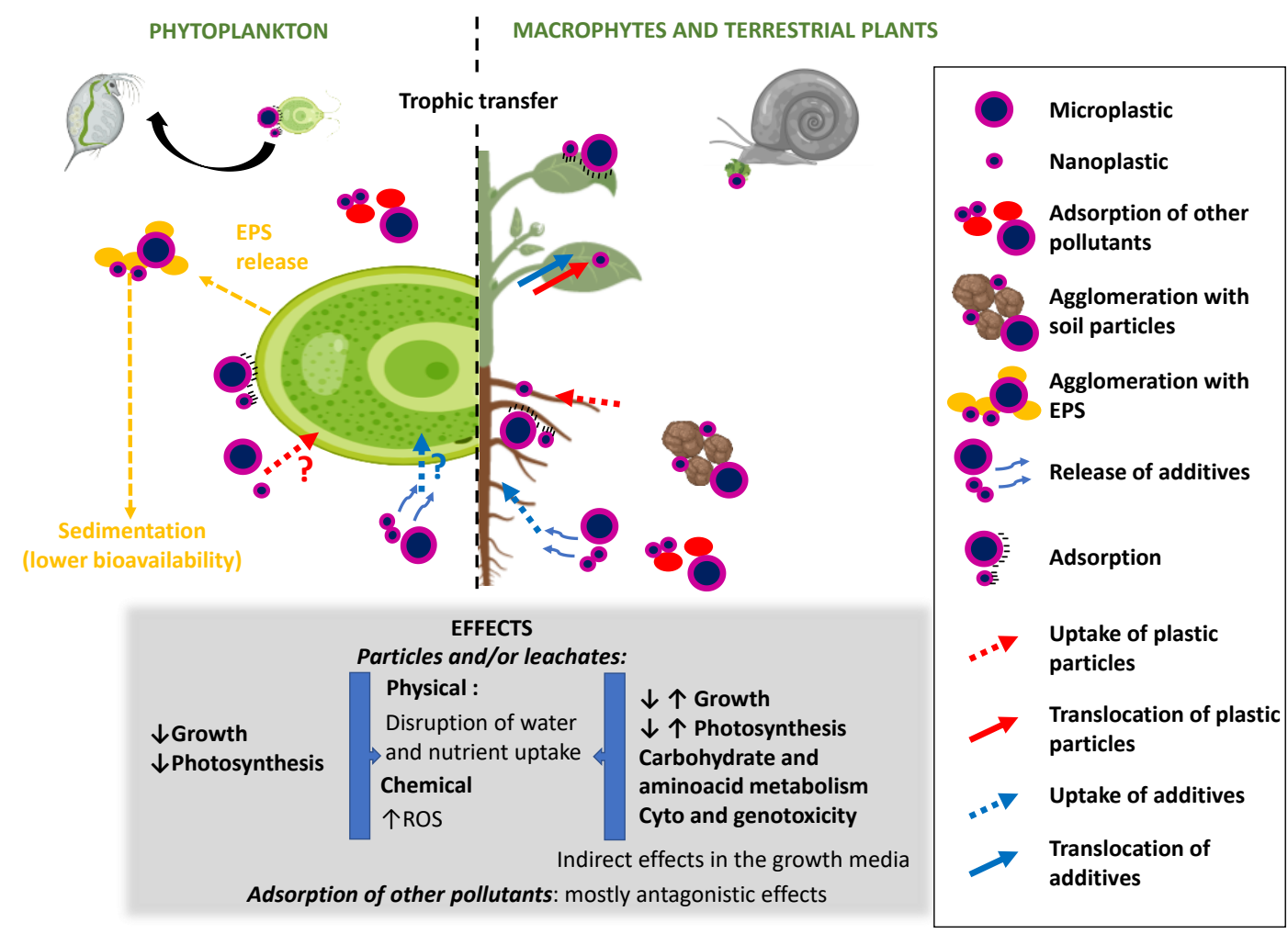

820

821

822

823

824

825

826

827

828

829

830

831

832

833

834

835

836

837

838

Figure 2. Synthesis of the interactions observed between micro and nanoplastics and photosynthetic organisms. Processes observed in both phytoplankton and macrophytes and terrestrial plants are placed in the middle of the scheme. (EPS: exopolymeric substances)

Phytotoxicity was visible mainly through decreased growth and impaired photosynthesis, the suggested mechanisms are either physical by disruption of the fluxes of water and nutrients or chemical by ROS induction. Other parameters can possibly influence the output of toxicity studies and should also be further investigated such as the influence of the species, developmental stages, experimental systems or exposure duration. It has also been shown that part of the toxicity is directly related with the leaching of additives and weathering products.

Toxicity studies should more systematically characterize the leachates, in order to clearly identify them as sources of phytotoxicity. More studies using genomic, proteomic and metabolomic techniques are needed to understand the mechanisms causing phytotoxicity in photosynthetic organisms exposed to plastics.

Trophic transfer is also of concern since it has been proven (both in the lab and in the field) that plastic particles can adhere to aquatic organism surface and thus be transferred to the upper trophic level. However, there is a lack of quantification of plastic inside the organisms (both aquatic and terrestrial) so the question of plastic internalization inside plant tissues, and in 
particular in edible parts in crop plants, is still a matter of debate. Uptake of additives such as phthalate esters in vegetables has been evidenced, leading to human exposure through the diet.

In addition, and following the trend of the research on engineered nanoparticles, studies should include aged plastics, which are more representative and environmentally relevant. So far, pristine spherical PS particles have been the most studied, although they are not representative of plastic particles spread in the environment, and even less representative of real aged particles. Working with these "real" particles is not ideal because experiment cannot be reproduced and results obtained are not comparable. Another strategy is to work with particles (and their leachates) after aging in controlled conditions. Also, in a more complex and realistic environment, plastic particles most probably interact with other contaminants and affect their toxicity, this should also be investigated further especially since aged plastic particles have a high sorption capacity. In addition, the response of organisms to combined stress (for example drought and micro nanoplastics) has been very little studied so far.

Concerning biodegradation, although some laboratory studies evidenced some loss of weight and some chemical degradation by microorganisms including photosynthetic ones, processes in environmental conditions and secondary products remains to be determined, and the kinetics is probably much slower than in laboratory experiments. The increasing concentrations of nano and micro-plastics in environmental compartments is the best evidence of the slow kinetics of both abiotic and biotic degradations.

More in depth research about nanoplastics will require the development of advanced detection techniques and sample preparation protocols that allow quantification of plastics in photosynthetic organisms. Main challenges include the detection limit of the techniques compared to environmental concentrations, and the similarity between micro and nanoplastics and natural organic compounds. In order to elucidate internalization in tissues and intra-cellular localization, microscopy methods capable of detecting non-labeled plastic particles unambiguously would be a breakthrough.

Other recommendation that can be formulated is the need for standardization of the methods for better intercomparison of the studies (using standard exposure conditions, standard methods for aging, ...) and the need for categorization. Indeed, micro and nanoplastics include a vast variety of compounds with different properties and toxicities, and there is a need to categorize them to speed the risk assessment process ${ }^{34,140}$. 


\section{Funding:}

875 This research did not receive any specific grant from funding agencies in the public, 876 commercial, or not-for-profit sectors. Ana E. Pradas del Real thanks "Atración de Talento" 877 program from Comunidad de Madrid for her fellowship. G. Sarret (ISTerre) is part of Labex 878 OSUG (ANR10 LABX56).

879

880

881

882

Bibliography

883

884

1. Turner, A. Heavy metals, metalloids and other hazardous elements in marine plastic

885 litter. Mar. Pollut. Bull. 111, 136-142 (2016).

886

2. Plastics Europe. Plastics - the Facts 2017. (2017).

887

3. Andrady, A. L. \& Neal, M. A. Applications and societal benefits of plastics. Philos. Trans. R. Soc. B 364, 1977-1984 (2009).

889

4. Alimi, O. S., Farner Budarz, J., Hernandez, L. M. \& Tufenkji, N. Microplastics and 890 Nanoplastics in Aquatic Environments: Aggregation, Deposition, and Enhanced Contaminant Transport. Environ. Sci. 52, 1704-1724 (2018).

893

5. Worm, B., Lotze, H. K., Jubinville, I., Wilcox, C. \& Jambeck, J. Plastic as a Persistent Marine Pollutant. Annu. Rev. Environ. Resour. 42, 1-26 (2017).

895

7. Horton, A. A., Walton, A., Spurgeon, D. J., Lahive, E. \& Svendsen, C. Microplastics in 897 freshwater and terrestrial environments : Evaluating the current understanding to identify 899 the knowledge gaps and future research priorities. Sci. Total Environ. 586, 127-141 (2017).

6. Allen, S. et al. Atmospheric transport and deposition of microplastics in a remote mountain catchment. Nat. Geosci. 12, 339-344 (2019).

9039 9. $\mathrm{Ng}$, E. L. et al. An overview of microplastic and nanoplastic pollution in agroecosystems. Sci. Total Environ. 627, 1377-1388 (2018). 
771 (2015).

11. Ter Halle, A. et al. Understanding the fragmentation pattern of marine plastic debris. Environ. Sci. Technol. 50, 5668-5675 (2016).

12. Fotopoulou, K. N. \& Karapanagioti, H. K. Surface properties of beached plastic pellets. Mar. Environ. Res. 81, 70-77 (2012).

13. Gigault, J. et al. Current opinion: What is a nanoplastic ? Environ. Pollut. 235, 10301034 (2018).

14. Yu, F., Yang, C., Zhu, Z., Bai, X. \& Ma, J. Adsorption behavior of organic pollutants and metals on micro / nanoplastics in the aquatic environment. Sci. Total Environ. 694, 133643 (2019).

15. Prunier, J. et al. Trace metals in polyethylene debris from the North Atlantic subtropical gyre. Environ. Pollut. 245, 371-379 (2019).

16. Holmes, L. A., Turner, A. \& Thompson, R. C. Interactions between trace metals and plastic production pellets under estuarine conditions. Mar. Chem. 167, 25-32 (2014).

17. Paluselli, A., Fauvelle, V., Galgani, F. \& Sempéré, R. Phthalate Release from Plastic Fragments and Degradation in Seawater. Environ. Sci. Technol. 53, 166-175 (2019).

18. Chae, Y. \& An, Y. Current research trends on plastic pollution and ecological impacts on the soil ecosystem : A review. Environ. Pollut. 240, 387-395 (2018).

19. Su, L. et al. Microplastics in Taihu Lake, China. Environ. Pollut. 216, 711-719 (2016).

20. Xu, S., Ma, J., Ji, R., Pan, K. \& Miao, A. Microplastics in aquatic environments: Occurrence, accumulation, and biological effects. Sci. Total Environ. 703, 134699 (2020).

21. Lechner, A. et al. The Danube so colourful: A potpourri of plastic litter outnumbers fish larvae in Europe's second largest river. Environ. Pollut. 188, 177-181 (2014).

22. Lasee, S. et al. Microplastics in a freshwater environment receiving treated wastewater effluent. Integr Env. Assess Manag 13, 528-532 (2017).

23. Dubaish, F. \& Liebezeit, G. Suspended Microplastics and Black Carbon Particles in the Jade System, Southern North Sea. Water Air Soil Pollut. 224, 1352 (2013).

24. Triebskorn, R. et al. Relevance of nano- and microplastics for freshwater ecosystems : A critical review. Trends Anal. Chem. 110, 375-392 (2019).

25. Correia Prata, J., da Costa, J. P., Lopes, I., Duarte, A. C. \& Rocha-Santos, T. Effects of microplastics on microalgae populations: A critical review. Sci. Total Environ. 665, 400-405 (2019).

26. Sharma, S. \& Chatterjee, S. Microplastic pollution, a threat to marine ecosystem and 
human health: a short review. Env. Sci Pollut Res Int 24, 21530-21547 (2017).

27. Peng, L. et al. Micro- and nano-plastics in marine environment: Source, distribution and threats - A review. Sci. Total Environ. 698, 134254 (2020).

28. Gao, G., Zhao, X., Jin, P., Gao, K. \& Beardall, J. Current understanding and challenges for aquatic primary producers in a world with rising micro- and nano-plastic levels. $J$. Hazard. Mater. 406, 124685 (2021).

29. Wang, W., Ge, J., Yu, X. \& Li, H. Environmental fate and impacts of microplastics in soil ecosystems: Progress and perspective. Sci. Total Environ. 708, 134841 (2020).

30. Rillig, M. C., Lehman, A., De Souza Machado, A. A. \& Yang, G. Microplastic effects on plants. New Phytol. 223, 1066-1070 (2019).

31. Nguyen, B. et al. Separation and Analysis of Microplastics and Nanoplastics in Complex Environmental Samples. Acc. Chem. Res. 52, 858-866 (2019).

32. Boyce, D. G., Lewis, M. R. \& Worm, B. Global phytoplankton decline over the past century. Nature 466, 591-596 (2010).

33. Bergami, E. et al. Long-term toxicity of surface-charged polystyrene nanoplastics to marine planktonic species Dunaliella tertiolecta and Artemia franciscana. Aquat. Toxicol. 189, 159-169 (2017).

34. Guo, Y. et al. Effects of microplastics on growth, phenanthrene stress, and lipid accumulation in a diatom, Phaeodactylum tricornutum. Environ. Pollut. 257, 113628 (2020).

35. Mao, Y. et al. Phytoplankton response to polystyrene microplastics : Perspective from an entire growth period. Chemosphere 208, 59-68 (2018).

36. Zhao, T., Tan, L., Huang, W. \& Wang, J. The interactions between micro polyvinyl chloride (mPVC ) and marine dinoflagellate Karenia mikimotoi: The inhibition of growth, chlorophyll and photosynthetic efficiency. Environ. Pollut. 247, 883-889 (2019).

37. Bellingeri, A. et al. Combined effects of nanoplastics and copper on the freshwater alga Raphidocelis subcapitata. Aquat. Toxicol. 210, 179-187 (2019).

38. Besseling, E., Wang, B., Lürling, M. \& Koelmans, A. A. Nanoplastic affects growth of S. obliquus and reproduction of D. magna. Env. Sci Technol 48, 12336-12343 (2014).

39. Bhattacharya, P., Lin, S., Turner, J. P. \& Ke, P. C. Physical Adsorption of Charged Plastic Nanoparticles Affects Algal Photosynthesis. J. Phys. Chem. C 114, 16556-16561 (2010).

40. Casado, M. P., Macken, A. \& Byrne, H. J. Ecotoxicological assessment of silica and 
polystyrene nanoparticles assessed by a multitrophic test battery. Environ. Int. 51, 97105 (2013).

41. Gonzalez-Fernandez, C. et al. Do transparent exopolymeric particles (TEP) affect the toxicity of nanoplastics on Chaetoceros neogracile? Environ. Pollut. 250, 873-882 (2019).

42. Sendra, M. et al. Are the primary characteristics of polystyrene nanoplastics responsible for toxicity and ad / absorption in the marine diatom Phaeodactylum tricornutum? Environ. Pollut. 249, 610-619 (2019).

43. Sjollema, S. B., Redondo-Hasselerharm, P., Leslie, H. A., Kraak, M. H. S. \& Vethaak, A. D. Do plastic particles affect microalgal photosynthesis and growth? Aquat. Toxicol. 170, 259-261 (2016).

44. Zhang, C., Chen, X., Wang, J. \& Tan, L. Toxic effects of microplastic on marine microalgae Skeletonema costatum: Interactions between microplastic and algae. Environ. Pollut. 220, 1282-1288 (2017).

45. Venâncio, C. et al. The effects of nanoplastics on marine plankton : A case study with polymethylmethacrylate. Ecotoxicol. Environ. Saf. 184, 109632 (2019).

46. Li, S. et al. Influence of polystyrene microplastics on the growth, photosynthetic efficiency and aggregation of freshwater microalgae Chlamydomonas reinhardtii. Sci. Total Environ. 714, 136767 (2020).

47. Li, Z. et al. Combined effect of polystyrene microplastics and dibutyl phthalate on the microalgae Chlorella pyrenoidosa. Environ. Pollut. 257, 113604 (2020).

48. Davarpanah, E. \& Guilhermino, L. Are gold nanoparticles and microplastics mixtures more toxic to the marine microalgae Tetraselmis chuii than the substances individually? Ecotoxicol. Environ. Saf. 181, 60-68 (2019).

49. Gambardella, C. et al. Microplastics do not affect standard ecotoxicological endpoints in marine unicellular organisms. Mar. Pollut. Bull. 143, 140-143 (2019).

50. Garrido, S., Linares, M., Campillo, J. A. \& Albentosa, M. Effect of microplastics on the toxicity of chlorpyrifos to the microalgae Isochrysis galbana, clone t-ISO. Ecotoxicol. Environ. Saf. 173, 103-109 (2019).

51. Long, M. et al. Interactions between polystyrene microplastics and marine phytoplankton lead to species-species hetero-aggregation. Environ. Pollut. 228, 454-463 (2017).

52. Prata, J. C., Lavorante, B. R. B. O., Montenegro, M. da C. B. S. M. \& Guilhermino, L. Influence of microplastics on the toxicity of the pharmaceuticals procainamide and 
doxycycline on the marine microalgae Tetraselmis chuii. Aquat. Toxicol. 197, 143-152 (2018).

53. Seoane, M. et al. Polystyrene microbeads modulate the energy metabolism of the marine diatom Chaetoceros neogracile. Environ. Pollut. 251, 363-371 (2019).

54. Davarpanah, E. \& Guilhermino, L. Single and combined effects of microplastics and copper on the population growth of the marine microalgae Tetraselmis chuii. Estuar. Coast. Shelf Sci. 167, 269-275 (2015).

55. Canniff, P. M. \& Hoang, T. C. Microplastic ingestion by Daphnia magna and its enhancement on algal growth. Sci. Total Environ. 633, 500-507 (2018).

56. Chae, Y., Kim, D. \& An, Y. Effects of micro-sized polyethylene spheres on the marine microalga Dunaliella salina: Focusing on the algal cell to plastic particle size ratio. Aquat. Toxicol. 216, 105296 (2019).

57. Zhu, Z. et al. Joint toxicity of microplastics with triclosan to marine microalgae Skeletonema costatum. Environ. Pollut. 246, 509-517 (2019).

58. Liu, G., Jiang, R., You, J., Muir, D. C. G. \& Zeng, E. Y. Microplastic Impacts on Microalgae Growth: E ff ects of Size and Humic Acid. Environ. Sci. Technol. 54, 17821789 (2020).

59. Nolte, T. M. et al. The toxicity of plastic nanoparticles to green algae as influenced by surface modification, medium hardness and cellular adsorption. Aquat. Toxicol. 183, $11-20$ (2017).

60. Thiagarajan, V. et al. Influence of differently functionalized polystyrene microplastics on the toxic effects of P25 TiO2 NPs towards marine algae Chlorella sp . Aquat. Toxicol. 207, 208-216 (2019).

61. Lagarde, F. et al. Microplastic interactions with freshwater microalgae: Heteroaggregation and changes in plastic density appear strongly dependent on polymer type. Environ. Pollut. 215, 331-339 (2016).

62. $\mathrm{Fu}, \mathrm{D}$. et al. Aged microplastics polyvinyl chloride interact with copper and cause oxidative stress towards microalgae Chlorella vulgaris. Aquat. Toxicol. 216, 105319 (2019).

63. Baudrimont, M. et al. Ecotoxicity of polyethylene nanoplastics from the North Atlantic oceanic gyre on freshwater and marine organisms (microalgae and filter-feeding bivalves). Env. Sci Pollut Res 27, 3746-3755 (2020).

64. Capolupo, M., Sørensen, L., Don Ranil Jayasena, K., Booth, A. M. \& Fabbri, E. Chemical composition and ecotoxicity of plastic and car tire rubber leachates to aquatic 
organisms. Water Res. 169, 115270 (2020).

65. Tetu, S. G. et al. Plastic leachates impair growth and oxygen production in Prochlorococcus, the ocean's most abundant photosynthetic bacteria. Commun. Biol. 2 , 184 (2019).

66. Luo, H. et al. Leaching behavior of fluorescent additives from microplastics and the toxicity of leachate to Chlorella vulgaris. Sci. Total Environ. 678, 1-9 (2019).

67. Luo, H. et al. Effects of accelerated aging on characteristics, leaching, and toxicity of commercial lead chromate pigmented microplastics. Environ. Pollut. 257, 113475 (2020).

68. Casabianca, S. et al. Physical interactions between marine phytoplankton and PET plastics in seawater. Chemosphere 238, 124560 (2020).

69. Cunha, C., Faria, M., Nogueira, N., Ferreira, A. \& Cordeiro, N. Marine vs freshwater microalgae exopolymers as biosolutions to microplastics pollution. Environ. Pollut. 249, 372-380 (2019).

70. Chen, C. et al. Effects of Engineered Nanoparticles on the Assembly of Exopolymeric Substances from Phytoplankton. PLoS One 6, e21865 (2011).

71. Garacci, M. et al. Few Layer Graphene sticking by biofilm of freshwater diatom Nitzschia palea as a mitigation to its ecotoxicity. Carbon N. Y. 113, 139-150 (2017).

72. Davranche, M. et al. Are nanoplastics able to bind significant amount of metals? The lead example. Enviornmental Pollut. 249, 940-948 (2019).

73. Zhang, Q. et al. The combined toxicity effect of nanoplastics and glyphosate on Microcystis aeruginosa growth. Environ. Pollut. 243, 1106-1112 (2018).

74. Chae, Y., Kim, D., Kim, S. W. \& An, Y.-J. Trophic transfer and individual impact of nano-sized polystyrene in a four-species freshwater food chain. Sci. Rep. 8, 284 (2018).

75. Xiao, Y. et al. Adverse physiological and molecular level effects of polystyrene microplastics on freshwater microalgae. Chemosphere 255, 126914 (2020).

76. Chae, Y., Hee Hong, S. \& An, Y. Photosynthesis enhancement in four marine microalgal species exposed to expanded polystyrene leachate. Ecotoxicol. Environ. Saf. 189, 109936 (2020).

77. Liao, Y., Jiang, X., Xiao, Y. \& Li, M. Exposure of microalgae Euglena gracilis to polystyrene microbeads and cadmium: Perspective from the physiological and transcriptional responses. Aquat. Toxicol. 228, 105650 (2020).

78. Ripken, C., Khalturin, K. \& Shoguchi, E. Response of Coral Reef Dinoflagellates to Nanoplastics under Experimental Conditions Suggests Downregulation of Cellular 
Metabolism. Microorganisms 8, 1759 (2020).

79. Debroas, D., Mone, A. \& Ter Halle, A. Plastics in the North Atlantic garbage patch : A boat-microbe for hitchhikers and plastic degraders. Sci. Total Environ. 599-600, 12221232 (2017).

80. Roager, L. \& Sonnenschein, E. C. Bacterial Candidates for Colonization and Degradation of Marine Plastic Debris. Environ. Sci. Technol. 53, 11636-11643 (2019).

81. Sarmah, P. \& Rout, J. Efficient biodegradation of low-density polyethylene by cyanobacteria isolated from submerged polyethylene surface in domestic sewage water. Environ. Sci. Pollut. Res. 25, 33508-33520 (2018).

82. Jacquin, J. et al. Microbial Ecotoxicology of Marine Plastic Debris: A Review on Colonization and Biodegradation by the 'Plastisphere'. Front. Microbiol. 10, (2019).

83. Oberbeckmann, S. \& Labrenz, M. Marine Microbial Assemblages on Microplastics: Diversity, Adaptation, and Role in Degradation. Ann. Rev. Mar. Sci. 12, 209-232 (2020).

84. Chia, W. Y., Tang, D. Y. Y., Khoo, K. S., Lup, A. N. K. \& Chew, K. W. Nature' s fight against plastic pollution: Algae for plastic biodegradation and bioplastics production. Environ. Sci. Ecotechnology 4, 100065 (2020).

85. Kumar, R. V., Kanna, G. R. \& Elumalai, S. Bioremediation \& Biodegradation Biodegradation of Polyethylene by Green Photosynthetic Microalgae. J. bioremediation Biodegrad. 8, 1000381 (2017).

86. Kim, J. W. et al. Functional expression of polyethylene terephthalate - degrading enzyme (PETase) in green microalgae. Microb. Cell Fact. 19, 97 (2020).

87. Moog, D. et al. Using a marine microalga as a chassis for polyethylene terephthalate (PET) degradation. Microb. Cell Fact. 18, 171 (2019).

88. Taipale, S. J. et al. Tracing the fate of microplastic carbon in the aquatic food web by compound-specific isotope analysis. Sci. Rep. 9, 18894 (2019).

89. Kalcikova, G., Zgajnar Gotvajn, A., Kladnik, A. \& Jemec, A. Impact of polyethylene microbeads on the floating freshwater plant duckweed Lemna minor. Environ. Pollut. 230, 1108-1115 (2017).

90. Kokalj, A. J., Kuehnel, D., Puntar, B., Zgajnar Gotvajn, A. \& Kalcikova, G. An exploratory ecotoxicity study of primary microplastics versus aged in natural waters and wastewaters. Environ. Pollut. 254, 112980 (2019).

91. Van Weert, S., Redondo-Hasselerharm, P. E., Diepens, N. J. \& Koelmans, A. A. Effects of nanoplastics and microplastics on the growth of sediment-rooted macrophytes. Sci. Total Environ. 654, 1040-1047 (2019). 
1110

1111

1112

1113

1114

1115

1116

1117

1118

1119

1120

1121

1122

1123

1124

1125

1126

1127

1128

1129

1130

1131

1132

1133

1134

1135

1136

1137

1138

1139

1140

1141

1142

1143

92. Sundbæk, K. B. et al. Sorption of fluorescent polystyrene microplastic particles to edible seaweed Fucus vesiculosus. J. Appl. Phycol. 30, 2923-2927 (2018).

93. Gutow, L., Eckerlebe, A., Gimenez, L. \& Saborowski, R. Experimental evaluation of seaweeds as a vector for microplastics into marine food webs. Environ. Sci. Technol. 50, 915-923 (2016).

94. Mateos-Cárdenas, A. et al. Polyethylene microplastics adhere to Lemna minor ( L .), yet have no effects on plant growth or feeding by Gammarus duebeni ( Lillj .). Sci. Total Environ. 689, 413-421 (2019).

95. Goss, H., Jaskiel, J. \& Rotjan, R. Thalassia testudinum as a potential vector for incorporating microplastics into benthic marine food webs. Mar. Pollut. Bull. 135, 10851089 (2018).

96. Saley, A. M. et al. Microplastic accumulation and biomagnification in a coastal marine reserve situated in a sparsely populated area. Mar. Pollut. Bull. 146, 54-59 (2019).

97. Pietrelli, L. et al. Pervasive plastisphere: First record of plastics in egagropiles (Posidonia spheroids ). Environ. Pollut. 229, 1032-1036 (2017).

98. Remy, F. et al. When microplastic is not plastic: the ingestion of artificial cellulose fibers by macrofauna living in seagrass macrophytodetritus. Environ. Sci. Technol. 49, 1115811166 (2015).

99. Hegan, D. et al. Determining time limits of continous film mulching and examining residual effects on cotton yield and soil properties. J. Environ. Biol. 36, 677-384 (2015).

100. Horton, A. A., Walton, A., Spurgeon, D. J., Lahive, E. \& Svendsen, C. Microplastics in freshwater and terrestrial environments: Evaluating the current understanding to identify the knowledge gaps and future research priorities. Sci. Total Environ. 586, 127-141 (2017).

101. van Kleunen, M., Brumer, A., Gutbrod, L. \& Zhang, Z. A microplastic used as infill material in artificial sport turfs reduces plant growth. Plants People Planet 1-10 (2019). doi:10.1002/ppp3.10071

102. Qi, Y. et al. Macro- and micro- plastics in soil-plant system : Effects of plastic mulch film residues on wheat (Triticum aestivum) growth. Sci. Total Environ. 645, 1048-1056 (2018).

103. Bosker, T., Bouwman, L. J., Brun, N. R., Behrens, P. \& Vijver, M. G. Microplastics accumulate on pores in seed capsule and delay germination and root growth of the terrestrial vascular plant Lepidium sativum. Chemosphere 226, 774-781 (2019).

104. Jiang, X., Chen, H., Liao, Y., Ye, Z. \& Li, M. Ecotoxicity and genotoxicity of 
polystyrene microplastics on higher plant Vicia faba. Environ. Pollut. 250, 831-838 (2019).

105. Boots, B., Russell, C. W. \& Green, D. S. Effects of Microplastics in Soil Ecosystems : Above and Below Ground. Env. Sci Technol 53, 11496-11506 (2019).

106. Anderson Abel de Souza Machado, Chung W. Lau, Werner Kloas, J. B. \& Julien B. Bachelier, Erik Faltin, Roland Becker, Anna S. Görlich, and M. C. R. Microplastics Can Change Soil Properties and A ff ect Plant Performance. Environ. Sci. Technol. 53, 60446052 (2019).

107. Sun, X. et al. Differentially charged nanoplastics demonstrate distinct accumulation in Arabidopsis thaliana. Nat. Nanotechnol. 15, 755-760 (2020).

108. Qi, Y. et al. Effects of plastic mulch film residues on wheat rhizosphere and soil properties. J. Hazard. Mater. 387, 121711 (2020).

109. Moraes Sinohara Souza, P., Corroque, N. A., Morales, A. R., Marin-Morales, M. A. \& Innocentini Mei, L. H. PLA and organoclays nanocomposites : degradation process and evaluation of ecotoxicity using Allium cepa as test organism. J Polym Env. 21, 10521063 (2013).

110. Menicagli, V., Balestri, E. \& Lardicci, C. Exposure of coastal dune vegetation to plastic bag leachates: A neglected impact of plastic litter. Sci. Total Environ. 683, 737-748 (2019).

111. Muroi, F., Tachibana, Y., Kobayashi, Y., Sakurai, T. \& Kasuya, K. Influences of poly(butylene adipate-co-terephthalate) on soil microbiota and plant growth. Polym. Degrad. Stab. 129, 338-346 (2016).

112. Dong, Y., Gao, M., Song, Z. \& Qiu, W. Microplastic particles increase arsenic toxicity to rice seedlings. Environ. Pollut. 259, 113892 (2020).

113. Lian, J. et al. Do polystyrene nanoplastics affect the toxicity of cadmium to wheat (Triticum aestivum L.)? Environ. Pollut. 263, 114498 (2020).

114. E.I. Atuanya, W. T. A. and N. A. N. Impact of Plastic Enriched Composting on Soil Structure, Fertility and Growth of Maize Plants. Eur. J. Appl. Sci. 4, 105-109 (2012).

115. Giorgetti, L. et al. Exploring the interaction between polystyrene nanoplastics and Allium cepa during germination: Internalization in root cells, induction of toxicity and oxidative stress. Plant Physiol. Biochem. 149, 170-177 (2020).

116. Wang, F., Zhang, X., Zhang, S., Zhang, S. \& Sun, Y. Interactions of microplastics and cadmium on plant growth and arbuscular mycorrhizal fungal communities in an agricultural soil. Chemosphere 254, 126791 (2020). 
117. Lian, J. et al. Impact of polystyrene nanoplastics (PSNPs) on seed germination and seedling growth of wheat (Triticum aestivum L.). J. Hazard. Mater. 385, 121620 (2020).

118. Taylor, S. E. et al. Polystyrene nano-and microplastic accumulation at Arabidopsis and wheat root cap cells, but no evidence for uptake into roots. Environ. Sci. Nano 7, 19421953 (2020).

119. Gopinath, P. M., Saranya, V. \& Vijayakumar, S. Assessment on interactive prospectives of nanoplastics with plasma proteins and the toxicological impacts of virgin, coronated and environmentally. Sci. Rep. 9, 8860 (2019).

120. Zhang, T., Wang, C., Dong, F., Gao, Z. \& Zhang, C. Uptake and Translocation of Styrene Maleic Anhydride Nanoparticles in Murraya Exotica Plants as Revealed by Noninvasive , Real-Time Optical Bioimaging. Env. Sci Technol 53, 1471-1481 (2019).

121. Chae, Y. \& An, Y.-J. Nanoplastic ingestion induces behavioral disorders in terrestrial snails: trophic transfer effect via vascular plants. Environ. Sci. Nano 7, 975-983 (2020).

122. Du, Q. Z., Fu, X. W. \& Xia, H. L. Uptake of di-(2-ethylhexyl ) phthalate from plastic mulch film by vegetable plants. Food Addit. Contam. Part A 26, 37-41 (2009).

123. Wang, J. et al. Occurrence and risk assessment of phthalate esters (PAEs) in vegetables and soils of suburban plastic film greenhouses. Sci. Total Environ. 523, 129-137 (2015).

124. Chen, N. et al. Contamination of Phthalate Esters in Vegetable Agriculture and Human Cumulative Risk Assessment. Pedosphere 27, 439-451 (2017).

125. Janczak, K., Hrynkiewicz, K., Znajewska, Z. \& Dąbrowska, G. Use of rhizosphere microorganisms in the biodegradation of PLA and PET polymers in compost soil. Int. Biodeterior. Biodegradation 130, 65-75 (2018).

126. Sangale, M. K., Shahnawaz, M. \& Ade, A. B. Potential of fungi isolated from the dumping sites mangrove rhizosphere soil to degrade polythene. Sci. Rep. 9, 5390 (2019).

127. Maes, T., Jessop, R., Wellner, N., Haupt, K. \& Mayes, A. G. A rapid-screening approach to detect and quantify microplastics based on fluorescent tagging with Nile Red. Sci. Rep. 7, 44501 (2017).

128. Suhling, K. et al. Fluorescence lifetime imaging (FLIM): Basic concepts and some recent developments. Med. Photonics 27, 3-40 (2015).

129. Mitrano, D. M. et al. Synthesis of metal-doped nanoplastics and their utility to investigate fate and behaviour in complex environmetal systems. Nat. Nanotechnol. 14, 362-368 (2019).

130. Schmiedgruber, M., Hufenus, R. \& Mitrano, D. M. Mechanistic Understanding of Microplastic Fiber Fate and Sampling Strategies: Synthesis and Utility of Metal Doped 
Polyester Fibers. Water Res. 155, 423-430 (2019).

1213

1214

1215

1216

1217

1218

1219

1220

1221

1222

1223

1224

1225

1226

1227

1228

1229

1230

1231

1232

1233

1234

1235

1236

1237

1238

1239

1240

1241

1242

1243

1244

1245

131. Käppler, A. et al. Analysis of environmental microplastics by vibrational microspectroscopy: FTIR, Raman or both? Anal. Bioanal. Chem. 408, 8377-8391 (2016).

132. Gierlinger, N. New insights into plant cell walls by vibrational microspectroscopy. Appl. Spectrosc. Rev. 53, 517-551 (2018).

133. Araujo, C. F., Nolasco, M. M., Ribeiro, A. M. P. \& Ribeiro-claro, P. J. A. Identification of microplastics using Raman spectroscopy : Latest developments and future prospects. Water Res. 142, 426-440 (2018).

134. Maguire, C. M., Rösslein, M., Wick, P. \& Prina-Mello, A. Characterisation of particles in solution - a perspective on light scattering and comparative technologies. Sci. Technol. Adv. Mater. 19, 732-745 (2018).

135. Powers, D. C., Powers, T. M. \& A\&M, T. Electron Paramagnetic Resonance (EPR) Spectroscopy. JoVE Science Education Database. (2020).

136. Zhu, K. et al. Formation of Environmentally Persistent Free Radicals on Microplastics under Light Irradiation. Environ. Sci. Technol. 53, 8177-8186 (2019).

137. Fries, E. et al. Identification of polymer types and additives in marine microplastic particles using pyrolysis-GC/MS and scanning electron microscopy. Environ. Sci. Process. Impacts 15, 1949-1956 (2013).

138. Elert, A. M. et al. Comparison of different methods for MP detection: What can we learn from them, and why asking the right question before measurements matters? Environ. Pollut. 231, 1256-1264 (2017).

139. Bolea-Fernandez, E., Rua-Ibarz, A., Velimirovic, M., Tirez, K. \& Vanhaecke, F. Detection of microplastics using inductively coupled plasma-mass spectrometry (ICPMS) operated in single-event mode. J. Anal. At. Spectrom. 35, 455-460 (2020).

140. Stone, V. et al. Nanomaterials for environmental studies: Classification, reference material issues, and strategies for physico-chemical characterisation. Sci. Total Environ. 408, 1745-1754 (2010).

141. Boots, B., Russell, C. W. \& Senga Green, D. Effects of microplastics in soil ecosystems: above and below ground. Environ. Sci. Technol. 53, 11496-11506 (2019).

142. De Souza Machado, A. A. et al. Microplastics Can Change Soil Properties and A ff ect Plant Performance. Env. Sci Technol 53, 6044-6052 (2019).

143. Qi, Y. et al. Macro- and micro- plastics in soil-plant system : Effects of plastic mulch film residues on wheat (Triticum aestivum) growth. Sci. Total Environ. 645, 1048-1056 
(2018).

1247 
Table 1. Summary of the main technical details of studies published in the literature so far dealing with the impacts of nano and microplastics on photosynthetic organisms. catalase (CAT), database of essential genes (DEG), diethylhexyl phthalate (DEHP), half maximal effective concentration (EC50), ethylene propylene diene monomer (EPDM), exopolymeric substances (EPS), humic acid (HA), high density (HD), half maximal inhibitory (PTFE), polyvinyl chloride (PVC), reactive oxygen species (ROS), superoxide dismutase (SOD)

\begin{tabular}{|c|c|c|c|c|c|c|c|c|c|}
\hline Species & $\begin{array}{l}\text { Growth } \\
\text { or living } \\
\text { medium }\end{array}$ & $\begin{array}{l}\text { Plastic } \\
\text { type }\end{array}$ & Coating & Size & $\begin{array}{l}\text { Concentr } \\
\text { ation }\end{array}$ & $\begin{array}{l}\text { Exposure } \\
\text { duration }\end{array}$ & $\begin{array}{c}\text { Co } \\
\text { exposur } \\
\text { e }\end{array}$ & Effects & Ref \\
\hline \multicolumn{10}{|c|}{ Microalgae } \\
\hline $\begin{array}{c}\text { Scenedesmus } \\
\text { subspicatus } \\
\text { Thalassiosira } \\
\text { weissiflogii }\end{array}$ & $\begin{array}{c}\text { fresh } \\
\text { water } \\
\text { seawater }\end{array}$ & $\begin{array}{l}\text { pristine } \\
\text { PE (PER) } \\
\text { and PE } \\
\text { from } \\
\text { ocean } \\
\text { (PEN) }\end{array}$ & & $350 \mu \mathrm{m}$ & $\begin{array}{l}0 \text { to } 1 \\
\mathrm{mg} / \mathrm{L}\end{array}$ & $48 \mathrm{~h}$ & & $\begin{array}{c}\text { - no influence on cell growth of } T \text {. weissiflogii } \\
\text { - PEN exposure caused growth inhibition of } S \text {. subspicatus } \\
\text { for all exposure concentrations tested } \\
\text { - recovery after some time } \\
\text { - PEN seemed more toxic (metal release?) }\end{array}$ & 63 \\
\hline $\begin{array}{l}\text { Raphidocelis } \\
\text { subcapitata } \\
\text { Skeletonema } \\
\text { costatum }\end{array}$ & $\begin{array}{c}\text { fresh } \\
\text { water } \\
\text { seawater, } \\
(\mathrm{DM} \\
\text { medium, } \\
\text { TG201 } \\
\text { medium) }\end{array}$ & $\begin{array}{l}\text { CTR (car } \\
\quad \text { tire } \\
\text { rubber), } \\
\text { PP, PET, } \\
\text { PS, PVC }\end{array}$ & & $\begin{array}{c}\text { leachates } \\
\text { of } 1000 \\
\mu \mathrm{m} \\
\text { particles }\end{array}$ & $\begin{array}{c}80 \mathrm{~g} / \mathrm{L} \text { for } \\
\text { leachate } \\
\text { preparatio } \\
\mathrm{n}\end{array}$ & $72 \mathrm{~h}$ & & $\begin{array}{c}\text { - in the leachates: plasticizers, antioxidants, antimicrobials, } \\
\text { lubricants, vulcanizers (between ng to hundreds of } \mu \mathrm{g} / \mathrm{L} \text { ) } \\
\text { - CTR and PVC contained the most additives } v s . \text { PET } \\
\text { - different leachate composition with fresh or sea waters for } \\
\text { inorganic contaminants } \\
\text { - all leachates (except PET) inhibited algal growth } \\
\text { - sorption of some inorganic nutrients at the plastic surface } \\
\text { (especially PS particle and } \mathrm{Mg} \text { ) }\end{array}$ & 64 \\
\hline $\begin{array}{c}\text { Skeletonema } \\
\text { marinoi } \\
\text { Lingulodinium } \\
\text { polyedrum }\end{array}$ & $\begin{array}{c}\text { seawater } \\
\text { (artificial) }\end{array}$ & PET & & $\begin{array}{l}\text { sheets } \\
4 \times 20 \\
\mathrm{~mm}\end{array}$ & & $\begin{array}{c}\text { up to } \\
16 \mathrm{~d}, \\
\text { log phase }\end{array}$ & & $\begin{array}{l}\text { - interactions between } S \text {. marinoi cells and plastic surface, } \\
\text { exponentially increasing as a function of incubation time } \\
\text { - L. polyedrum showed lower adsorption. Siloxane groups of } \\
\text { the silica frustule involved in the binding with the } \\
\text { hydrophobic plastic surface }\end{array}$ & 68 \\
\hline
\end{tabular}




\begin{tabular}{|c|c|c|c|c|c|c|c|c|}
\hline $\begin{array}{l}\text { Dunaliella salina } \\
\text { Scenedesmus } \\
\text { rubescens } \\
\text { Chlorella } \\
\text { saccharophila } \\
\text { Stichococcus } \\
\text { bacillaris }\end{array}$ & $\begin{array}{l}\text { seawater } \\
\quad(\mathrm{f} / 2 \\
\text { medium })\end{array}$ & $\begin{array}{l}\text { expanded } \\
\text { PS }\end{array}$ & $\begin{array}{l}\text { fragment: } \\
2 \mathrm{~mm} \text { to } \\
10 \mathrm{~cm}^{2} \\
\text { sphere: } 2 \\
\text { to } 10 \mathrm{~mm}\end{array}$ & $\begin{array}{l}\text { leachate: } \\
0.1 \mathrm{~g} / 50 \\
\mathrm{~mL} \text { or } 10 \\
\text { and } 30 \\
\text { items } / 50 \\
\quad \mathrm{~mL} \\
\text { checked } \\
\text { for } 28 \mathrm{~d}\end{array}$ & $7 d$ & & $\begin{array}{c}\text { - leachate exposure (especially from smaller fragments) } \\
\text { increased photosynthetic activity in all } 4 \text { species } \\
\text { - in the leachates: hexabromocyclododecane, UV326, } \\
\text { bisphenol-A }\end{array}$ & 76 \\
\hline $\begin{array}{l}\text { Phaeodactylum } \\
\text { tricornutum }\end{array}$ & $\begin{array}{c}\text { seawater } \\
\text { (artificial) }\end{array}$ & $\begin{array}{c}\mathrm{PE} \\
\mathrm{PVC}\end{array}$ & $\begin{array}{l}150 \mu \mathrm{m} \\
250 \mu \mathrm{m}\end{array}$ & $\begin{array}{l}50,1000 \\
50000 \\
\mathrm{mg} / \mathrm{L}\end{array}$ & $\begin{array}{l}4 \mathrm{~d}-9 \mathrm{~d}, \\
\log \text { and } \\
\text { stationary } \\
\text { phases }\end{array}$ & $\begin{array}{l}\text { phenant } \\
\text { hrene } \\
(0.8 \\
\mathrm{mg} / \mathrm{L})\end{array}$ & $\begin{array}{l}\text { - both plastic types did not influence algal growth and lipid } \\
\text { accumulation after } 4 \mathrm{~d} \text { but minimized algal inhibition by the } \\
\text { action of Phe (more effects at } 9 \mathrm{~d} \text { ) } \\
\text { - polymer-size was the key factor influencing plastic toxicity }\end{array}$ & 34 \\
\hline $\begin{array}{l}\text { Chlamydomonas } \\
\text { reinhardtii }\end{array}$ & $\begin{array}{l}\text { fresh } \\
\text { water } \\
(\mathrm{SE} \\
\text { medium) }\end{array}$ & PS & $\begin{array}{c}300-600 \\
n m\end{array}$ & $\begin{array}{l}5 \text { to } 100 \\
\mathrm{mg} / \mathrm{L}\end{array}$ & $\begin{array}{c}10 \mathrm{~d}, \\
\text { log phase }\end{array}$ & & $\begin{array}{c}\text { - microalgae density decreased as plastic concentration } \\
\text { increase: highest inhibitory rate was } 45.8 \% \\
\text { - inhibition of EPS release } \\
\text { - decrease in chloro fluorescence yield/photosynthetic } \\
\text { activities } \\
\text { - increase of soluble proteins and MDA content } \\
\text { - plastic wrapped on algae surface inducing membrane } \\
\text { damages }\end{array}$ & 46 \\
\hline $\begin{array}{c}\text { Chlorella } \\
\text { pyrenoidosa }\end{array}$ & $\begin{array}{c}\text { seawater } \\
\text { (artificial) }\end{array}$ & PS & $\begin{array}{l}0.1,0.55 \\
5 \mu \mathrm{m}\end{array}$ & $\begin{array}{l}\text { up to } 64 \\
\text { mg/L }\end{array}$ & $\begin{array}{c}96 \mathrm{~h}, \\
\text { log phase }\end{array}$ & $\begin{array}{l}\text { DBP : } \\
\text { dibutyl } \\
\text { phtalate }\end{array}$ & $\begin{array}{c}-\mathrm{IC}_{50} \approx 7 \mathrm{mg} / \mathrm{L} \text { for PS alone } \\
\text { - size dependent inhibitory effect } \\
\text { - modeling showed antagonist interactions between the } 2 \\
\text { contaminants }(20 \mathrm{mg} / \mathrm{L} \text { PS lead to a } 20 \% \text { decrease in the } \\
\text { toxicity of DBP) } \\
\text { - biomarkers: cell volume, morphological complexity and } \\
\text { chlorophyll fluorescence }\end{array}$ & 47 \\
\hline Euglena gracilis & $\begin{array}{l}\text { fresh } \\
\text { water } \\
\text { (sterilized } \\
\text { growth } \\
\text { medium) }\end{array}$ & PS & $\begin{array}{l}100 \mathrm{~nm} \\
5 \mu \mathrm{m}\end{array}$ & $1 \mathrm{mg} / \mathrm{L}$ & $96 \mathrm{~h}$ & $\begin{array}{c}\mathrm{Cd} \\
(0.5 \\
\mathrm{mg} / \mathrm{L})\end{array}$ & $\begin{array}{c}\text { - toxicity of microPS > nanoPS (growth inhibition, oxidative } \\
\text { damage, decreased photosynthesis pigment) } \\
\text { - microPS alone or with Cd caused cavitation and increased } \\
\text { the number and volume of vacuoles } \\
\text { - combined exposure toxicity Cd + nanoPS }>\mathrm{Cd}+\text { microPS } \\
\text { - DEGs in Cd + nanoPS enriched in metabolism-related } \\
\text { pathways } \\
\text { - no adsorption of } 0.5 \mathrm{mg} / \mathrm{L} \mathrm{Cd} \text { to } 1 \mathrm{mg} / \mathrm{L} \text { PS microbeads }\end{array}$ & 77 \\
\hline
\end{tabular}




\begin{tabular}{|c|c|c|c|c|c|c|c|c|c|}
\hline $\begin{array}{c}\text { Scenedesmus } \\
\text { obliquus }\end{array}$ & $\begin{array}{c}\text { fresh } \\
\text { water } \\
\text { (BG-11 } \\
\text { medium) }\end{array}$ & PS & $\begin{array}{c}-\mathrm{COOH} \\
-\mathrm{NH}_{2}\end{array}$ & $\begin{array}{c}0.1,0.5,1 \\
2 \mu \mathrm{m}\end{array}$ & $\begin{array}{l}75 \mathrm{mg} / \mathrm{L} \\
\text { and up to } \\
250 \mathrm{mg} / \mathrm{L}\end{array}$ & $\begin{array}{c}150 \mathrm{~h}, \\
\text { log phase }\end{array}$ & $\begin{array}{l}\text { humic } \\
\text { acid }\end{array}$ & $\begin{array}{c}\text { - no significant impact on the } \mathrm{EC}_{50} \\
\text { - larger size particles blocked light transport affecting } \\
\text { photosynthesis } \\
\text { - smaller particles destroyed cell walls after adsorption } \\
\text { - HA alleviated toxicity of small particles by forming a } \\
\text { corona around, decreasing plastic affinity for algae }\end{array}$ & 58 \\
\hline $\begin{array}{c}\text { Microcystis } \\
\text { aeruginosa }\end{array}$ & $\begin{array}{c}\text { fresh } \\
\text { water } \\
\text { (BG-11 } \\
\text { medium) }\end{array}$ & PE & & $<500 \mu \mathrm{m}$ & $\begin{array}{l}\text { leachate: } \\
0.5 \mathrm{~g} \mathrm{/} \\
300 \mathrm{~mL} \\
\text { for up to } \\
\quad 96 \mathrm{~h}\end{array}$ & $12 \mathrm{~h}$ & & $\begin{array}{l}\text { - aging led to surface cracks and fragmentation, increased } \\
\text { surface area and carbonyl contents, and promoted the release } \\
\text { of } \mathrm{Pb} \text { chromate pigment } \\
\text { - } \mathrm{Cr} \text { and } \mathrm{Pb} \text { leached more under acidic condition, rather than } \\
\text { neutral and alkali environment } \\
\text { - high concentration of } \mathrm{NaCl} \text { favored leaching } \\
\text { - concentration of leachate }>10 \mu \mathrm{g} / \mathrm{L} \text { decreased } \\
\text { photosynthesis } \\
\text { - growth inhibition increased with leachate concentration }\end{array}$ & 67 \\
\hline $\begin{array}{l}\text { Symbiodinium } \\
\text { tridacnidorum, } \\
\text { Cladocopium sp. }\end{array}$ & $\begin{array}{c}\text { seawater } \\
\text { (articifial } \\
+\mathrm{f} / 2 \\
\text { medium) }\end{array}$ & PS & & $42 \mathrm{~nm}$ & $\begin{array}{c}0.01,0.1 \\
10 \mathrm{mg} / \mathrm{L}\end{array}$ & $10 \mathrm{~d}$ & & $\begin{array}{c}\text { - cell number and aggregation reduced } \\
\text { - no clear correlation with plastic concentration } \\
\text { - genes involved in dynein motor function upregulated } v s \text {. } \\
\text { genes related to photosynthesis, mitosis, and intracellular } \\
\text { degradation downregulated } \\
\text { - different sensitivity to nanoplastics between species }\end{array}$ & 78 \\
\hline Euglena gracilis & \begin{tabular}{c|}
$\begin{array}{c}\text { fresh } \\
\text { water } \\
\text { (sterilized } \\
\text { growth } \\
\text { medium) }\end{array}$ \\
\end{tabular} & PS & & $\begin{array}{c}100 \mathrm{~nm}, \\
5 \mu \mathrm{m}\end{array}$ & $1 \mathrm{mg} / \mathrm{L}$ & $96 \mathrm{~h}$ & & $\begin{array}{l}\text { - induction of vacuoles and superoxide dismutase and } \\
\text { peroxidase activities, reduction of pigment contents } \\
\text { - dysregulation in gene expression in } \\
\text { cellular processes, genetic information processing, } \\
\text { organismal systems, and metabolism }\end{array}$ & 75 \\
\hline $\begin{array}{c}\text { Raphidocelis } \\
\text { subcapitata }\end{array}$ & $\begin{array}{c}\text { fresh } \\
\text { water } \\
\text { (WC } \\
\text { medium) }\end{array}$ & PS & $-\mathrm{COOH}$ & $<1 \mu \mathrm{m}$ & $\begin{array}{l}0.5 \text { to } 50 \\
\mathrm{mg} / \mathrm{L}\end{array}$ & $\begin{array}{l}72 \mathrm{~h}, 7 \mathrm{~d} \\
\text { log phase }\end{array}$ & $\begin{array}{c}\mathrm{Cu} \\
(1 \text { to } \\
200 \\
\mu \mathrm{g} / \mathrm{L})\end{array}$ & $\begin{array}{l}\text { - algae secreted EPS, creating a protein corona around } \\
\text { nanoplastics } \\
\text { - no adsorption of } \mathrm{Cu} \text { on plastic surface } \\
\text { - PS had no impact on } \mathrm{Cu} \text { toxicity (no toxicity) } \\
\text { - plastic led to structural damages after } 72 \mathrm{~h} \\
\end{array}$ & 37 \\
\hline Dunaliella salina & $\begin{array}{l}\text { seawater } \\
(\mathrm{f} / 2 \\
\text { medium })\end{array}$ & $\mathrm{PE}$ & & $200 \mu \mathrm{m}$ & $\begin{array}{l}\text { up to } 350 \\
\mathrm{mg} / \mathrm{L}\end{array}$ & $6 \mathrm{~d}$ & & $\begin{array}{l}\text { - growth and photosynthetic activity enhanced with exposure } \\
\text { to plastic } \\
\text { - cell morphology (size and granularity) not impacted } \\
\text { - implication of trace concentrations of additive chemicals } \\
\text { (endocrine disruptors, phthalates, stabilizers)? }\end{array}$ & 56 \\
\hline
\end{tabular}




\begin{tabular}{|c|c|c|c|c|c|c|c|c|c|}
\hline $\begin{array}{l}\text { Microcystis } \\
\text { panniformis } \\
\text { Scenedesmus sp. } \\
\text { Tetraselmis sp. } \\
\text { Gloeocapsa sp. }\end{array}$ & $\begin{array}{l}\text { fresh } \\
\text { water } \\
(\mathrm{BG}-11 \\
\text { medium) } \\
\text { seawater } \\
\quad(\mathrm{f} / 2 \\
\text { medium })\end{array}$ & $\begin{array}{l}\text { PMMA } \\
\text { PS }\end{array}$ & & $\begin{array}{l}<106 \mu \mathrm{m} \\
106 \text { to } \\
250 \mu \mathrm{m}\end{array}$ & $\begin{array}{c}12.5 \text { and } \\
125 \mathrm{mg} / \mathrm{L}\end{array}$ & $21 \mathrm{~d}$ & & $\begin{array}{c}\text { - cell abundance decreased (up to } 42 \% \text { ) } \\
\text { - formation of homo-aggregates (microalgae and EPS) and } \\
\text { hetero-aggregates (microalgae, EPS and microparticles) } \\
\text { - hetero-aggregation was dependent on particle size and yield } \\
\text { production of EPS, which was species specific }\end{array}$ & 69 \\
\hline Tetraselmis chuii & $\begin{array}{l}\text { seawater } \\
\quad(\mathrm{f} / 2 \\
\text { medium })\end{array}$ & $\begin{array}{l}\text { unknown } \\
\text { compositi } \\
\text { on }\end{array}$ & & 1 to $5 \mu \mathrm{m}$ & $\begin{array}{c}0.3,0.9 \\
4 \mathrm{mg} / \mathrm{L}\end{array}$ & $\begin{array}{c}96 \mathrm{~h} \\
\text { log phase }\end{array}$ & $\begin{array}{l}\mathrm{Au} \\
\text { nanopart } \\
\text { icle }(5 \\
\mathrm{nm}) \\
0.1,0.3 \\
3 \mathrm{mg} / \mathrm{L}\end{array}$ & $\begin{array}{l}\text { - Au nanoparticle alone and microplastics alone did not cause } \\
\text { significant decrease of average specific growth rate, } \\
\text { - the mixture at the highest concentration was toxic }\end{array}$ & 48 \\
\hline $\begin{array}{l}\text { Chlorella } \\
\text { vulgaris }\end{array}$ & $\begin{array}{c}\text { seawater } \\
\text { (artificial) }\end{array}$ & PVC & & $? ?$ & $\begin{array}{l}10,100 \\
1000 \\
\mathrm{mg} / \mathrm{L}\end{array}$ & $\begin{array}{c}\text { aging: } 2 \\
\text { months } \\
\text { exposure : } \\
10 \mathrm{~d}\end{array}$ & $\begin{array}{l}\mathrm{Cu} \\
(0.2 \\
0.5,1 \\
\mathrm{mg} / \mathrm{L})\end{array}$ & $\begin{array}{c}\text { - aging led to surface structural changes and increased } \\
\text { hydroxyl groups and aromatic carbon-carbon double bond } \\
\text { but decreased carbon hydrogen bond } \\
\text { - toxicity at } 10 \mathrm{mg} / \mathrm{L} \text { but not above } \\
\text { - aged particles were more toxic (35 vs. } 28 \% \text { growth } \\
\text { inhibition) } \\
\text { - oxidative stress (increased of SOD and MDA) } \\
\text { - algal growth enhanced by Cu ( } 0.5 \mathrm{mg} / \mathrm{L})+ \text { aged PVC (10 } \\
\text { mg/L) after } 10 \text { days (but decreased at earlier stages) }\end{array}$ & 62 \\
\hline $\begin{array}{l}\text { Phaeodactylum } \\
\text { tricornutum }\end{array}$ & $\begin{array}{l}\text { seawater } \\
\text { (natural }+ \\
\mathrm{f} / 2 \\
\text { medium) }\end{array}$ & $\mathrm{PE}$ & $\begin{array}{l}\text { virgin or } \\
\text { oxydize } \\
\quad \mathrm{d}\end{array}$ & $\begin{array}{l}\text { from } 1 \text { to } \\
500 \mu \mathrm{m}\end{array}$ & $\begin{array}{l}0.01 \text { to } 25 \\
\mathrm{mg} / \mathrm{L}\end{array}$ & $\begin{array}{c}72 \mathrm{~h}, \\
\text { log phase }\end{array}$ & & $\begin{array}{c}\text { - no acute toxicity } \\
\text { - standard ecotoxicological endpoints not sufficiently } \\
\text { sensitive to assess the potential effects of microplastics ( } v s \text {. } \\
\text { for nanoplastics) } \\
-\mathrm{EC}_{50}>25 \mathrm{mg} / \mathrm{L}\end{array}$ & 49 \\
\hline $\begin{array}{l}\text { Isochrysis } \\
\text { galbana }\end{array}$ & $\begin{array}{l}\text { seawater } \\
\text { (Walne } \\
\text { medium } \\
\quad+ \\
\text { surfactant } \\
\quad \text { ) } \\
\end{array}$ & $\mathrm{PE}$ & & $\begin{array}{l}\text { from } 2 \text { to } \\
\quad 6 \mu \mathrm{m}\end{array}$ & $\begin{array}{l}\text { up to } 25 \\
\mathrm{mg} / \mathrm{L}\end{array}$ & $72 \mathrm{~h}$ & $\begin{array}{l}\text { CPF: } \\
\text { chlorpyr } \\
\text { ifos } \\
\text { (up to } 4 \\
\text { mg/L) }\end{array}$ & $\begin{array}{c}\text { - no impact of plastics on growth } \\
\text { - growth decreased by exposure to CPF from } 2 \mathrm{mg} / \mathrm{L} \\
\text { - } 80 \% \text { of CPF was sorbed onto plastic surfaces }(5 \mathrm{mg} / \mathrm{L}) \\
\text { - lower percentages of inhibition when CPF in association } \\
\text { with plastics } \\
\text { - microplastics less bioavailable than CPF }\end{array}$ & 50 \\
\hline $\begin{array}{c}\text { Chaetoceros } \\
\text { neogracile }\end{array}$ & seawater & PS & $-\mathrm{NH}_{2}$ & $50 \mathrm{~nm}$ & $\begin{array}{c}0.05,5 \\
\mathrm{mg} / \mathrm{L}\end{array}$ & $\begin{array}{l}4 \mathrm{~d} \\
\log \text { and } \\
\text { stationary } \\
\text { phases }\end{array}$ & & $\begin{array}{l}\text { - more toxicity during exponential than stationary phase } \\
\text { (ROS production) } \\
\text { - relation with higher concentration of transparent } \\
\text { exopolymer particles at stationary phase leading to NP } \\
\text { aggregation and/or with the fact that dividing cells during }\end{array}$ & 41 \\
\hline
\end{tabular}




\begin{tabular}{|c|c|c|c|c|c|c|c|c|c|}
\hline & & & & & & & & $\begin{array}{c}\text { exponential phase may be intrinsically more sensitive to } \\
\text { stress? }\end{array}$ & \\
\hline $\begin{array}{l}\text { Chlorella } \\
\text { vulgaris }\end{array}$ & $\begin{array}{c}\text { simulated } \\
\text { acidic, } \\
\text { saline, } \\
\text { basic } \\
\text { water and } \\
\text { natural } \\
\text { waters } \\
\text { river, } \\
\text { lake, } \\
\text { wetland, } \\
\text { seawater } \\
\end{array}$ & $\begin{array}{l}\text { polyureth } \\
\text { ane foam } \\
\text { (PUF) }\end{array}$ & & $\begin{array}{l}\text { leachates: } \\
3 \text { mm } \\
\text { side, } \\
12 \\
\text { months } \\
\text { aging }\end{array}$ & $350 \mathrm{mg} / \mathrm{L}$ & & & $\begin{array}{c}\text { - release amount of additives increased with increasing } \\
\text { solution } \mathrm{pH} \text { and leaching time } \\
\text { - maximum amount after } 12-24 \mathrm{~h} \\
\text { - 3,3'-diaminobenzidine-like substances identified in the } \\
\text { leachate } \\
\text { - leaching basic water }>\text { saline water }>\text { seawater }>\text { lake }> \\
\text { river }>\text { wetland } \\
\text { - Fv/Fm decreased with increasing leachate concentrations } \\
\text { - only high content of plastics }(1.6 \mathrm{~g} / \mathrm{L}) \text { decreased } \\
\text { photosynthesis }\end{array}$ & 66 \\
\hline Prochlorococcus & $\begin{array}{l}\text { seawater } \\
\text { (artificial) }\end{array}$ & $\begin{array}{l}\text { HDPE } \\
\text { from bags } \\
\text { PVC from } \\
\text { matting }\end{array}$ & & $1-2 \mathrm{~cm}^{2}$ & $\begin{array}{l}\text { leachates: } \\
50 \mathrm{~g} / \mathrm{L} \\
\text { plastic } \\
\text { pieces for } \\
5 \mathrm{~d}\end{array}$ & $\begin{array}{c}72 \mathrm{~h}, \\
\text { log phase }\end{array}$ & & $\begin{array}{l}\text { - leachate exposure strongly impaired growth and } \\
\text { photosynthetic capacity and resulted in genome-wide } \\
\text { transcriptional changes } \\
\text { - PVC leachate had a considerably greater effect than HDPE }\end{array}$ & 65 \\
\hline Chlorella sp. & $\begin{array}{c}\text { seawater } \\
\text { (artificial) }\end{array}$ & PS & $\begin{array}{l}-\mathrm{NH}_{2} \\
-\mathrm{COOH} \\
- \text { non } \\
\text { function } \\
\text { alized }\end{array}$ & $6 \mu \mathrm{m}$ & $\begin{array}{l}1000 \\
\mathrm{mg} / \mathrm{L}\end{array}$ & $\begin{array}{c}72 \mathrm{~h}, \\
\text { log phase }\end{array}$ & $\begin{array}{c}\mathrm{TiO}_{2} \\
\text { nanopart } \\
\text { icles }\end{array}$ & $\begin{array}{c}-\mathrm{EC}_{50} \mathrm{TiO}_{2}=81 \mu \mathrm{M} \\
- \text { only } 15 \% \text { toxicity of MP at } 1000 \mathrm{mg} / \mathrm{L} \\
\text { - } \mathrm{NH}_{2} \text { and non-functionalized MPs enhanced } \mathrm{TiO}_{2} \text { toxicity } \\
\text { (oxidative stress) } \\
\text {-COOH MPs decreased } \mathrm{TiO}_{2} \text { toxicity (hetero-aggregation) }\end{array}$ & 60 \\
\hline $\begin{array}{c}\text { Phaeodactylum } \\
\text { tricornutum }\end{array}$ & $\begin{array}{l}\text { seawater } \\
\text { (artificial } \\
\quad+\mathrm{f} / 2 \\
\text { medium) }\end{array}$ & PS & & $\begin{array}{l}50,100 \\
\mathrm{~nm}\end{array}$ & $\begin{array}{l}0.1 \text { to } 50 \\
\mathrm{mg} / \mathrm{L}\end{array}$ & $72 \mathrm{~h}$ & & $\begin{array}{c}\text { - after } 24 \mathrm{~h} \text {, oxidative stress, damage to the photosynthetic } \\
\text { apparatus, DNA damage and depolarization of mitochondrial } \\
\text { and cell membrane from } 5 \mathrm{mg} / \mathrm{L} \\
\text { - after } 72 \mathrm{~h} \text {, inhibition of growth and chlorophyll } \\
\text { - smallest NPs }(50 \mathrm{~nm}) \text { induced greater effects at } 24 \mathrm{~h} \text { while } \\
\text { bigger nanoparticles }(100 \mathrm{~nm}) \text { did at } 72 \mathrm{~h} \\
\text { - strong adsorption }\end{array}$ & 42 \\
\hline
\end{tabular}




\begin{tabular}{|c|c|c|c|c|c|c|c|c|c|}
\hline $\begin{array}{c}\text { Chaetoceros } \\
\text { neogracile }\end{array}$ & seawater & PS & $-\mathrm{NH}_{2}$ & $\begin{array}{l}0.5,2 \mu \mathrm{m} \\
(50 \mathrm{~nm})\end{array}$ & $2.5 \mathrm{mg} / \mathrm{L}$ & $\begin{array}{c}72 \mathrm{~h}, \\
\text { log phase }\end{array}$ & & $\begin{array}{c}\text { - strong aggregation } \\
\text { - negative charges in the culture medium decreasing } \\
\text { interactions with microalgae : no adsorption } \\
\text { - cell growth, morphology, photosynthesis, reactive oxygen } \\
\text { species levels and membrane potential unaltered } \\
\text { - significantly decreased cellular esterase activity and neutral } \\
\text { lipid content } \\
\text { - microplastic-exposed cells modulate their energy } \\
\text { metabolism to properly acclimate to stress conditions }\end{array}$ & 53 \\
\hline $\begin{array}{l}\text { Tetraselmis chuii } \\
\text { Nannochloropsis } \\
\text { gaditana } \\
\text { Isochrysis } \\
\text { galbana } \\
\text { Thalassiosira } \\
\text { weissflogii }\end{array}$ & $\begin{array}{l}\text { seawater } \\
\text { (natural + } \\
\mathrm{f} / 2 \\
\text { medium) }\end{array}$ & PMMA & & $\begin{array}{l}40 \mathrm{~nm} \\
50 \mathrm{~nm}\end{array}$ & $\begin{array}{c}0 \text { to } 300 \\
\mathrm{mg} / \mathrm{L}\end{array}$ & $96 \mathrm{~h}$ & & $\begin{array}{l}\text { - T. weissflogii and } T \text {. chuii were respectively the most } \\
\text { sensitive }\left(\mathrm{EC}_{50}=83.75 \mathrm{mg} / \mathrm{L}\right) \text { and least sensitive species } \\
\left(\mathrm{EC}_{50}=132.52 \mathrm{mg} / \mathrm{L}\right)\end{array}$ & 45 \\
\hline $\begin{array}{l}\text { Karenia } \\
\text { mikimitoi }\end{array}$ & $\begin{array}{l}\text { seawater } \\
\text { (natural) }\end{array}$ & PVC & & $1 \mu \mathrm{m}$ & $100 \mathrm{mg} / \mathrm{L}$ & $\begin{array}{l}24,48,72 \\
96 \mathrm{~h} \\
\text { log phase }\end{array}$ & & $\begin{array}{c}\text { - dose dependent adverse effect on growth } \\
\text { - decreased in chlorophyll content and photosynthetic } \\
\text { efficiency } \\
\text { - related to physical blockage (algae wrapped by plastic) and } \\
\text { aggregation } \\
\text { - after } 96 \text { h decrease of the toxicity }\end{array}$ & 36 \\
\hline $\begin{array}{l}\text { Skeletonema } \\
\text { costatum }\end{array}$ & $\begin{array}{l}\text { seawater } \\
\text { (artificial } \\
\text { seawater } \\
\quad+\mathrm{f} / 2 \\
\text { medium) }\end{array}$ & $\begin{array}{l}\text { PE } \\
\text { PS } \\
\text { PVC }\end{array}$ & & $\begin{array}{l}74 \mu \mathrm{m}(+ \\
1 \mu \mathrm{m} \\
\text { PVC) }\end{array}$ & $\begin{array}{l}\text { up to } 100 \\
\mathrm{mg} / \mathrm{L}\end{array}$ & $\begin{array}{c}96 \mathrm{~h} \\
\text { log phase }\end{array}$ & $\begin{array}{l}\text { TCS: } \\
\text { triclosan } \\
\text { (up to } \\
0.4 \\
\mathrm{mg} / \mathrm{L} \text { ) }\end{array}$ & $\begin{array}{c}\text { - TCS had obvious inhibition effect } \\
\text { - single particles also had significant inhibition effect which } \\
\text { followed the order of PVC } 1 \mu \mathrm{m}>\text { PVC }>\text { PS }>\text { PE } \\
\text { - joint toxicity of PVC and PVC } 1 \mu \mathrm{m} \text { with TCS, maybe } \\
\text { related to higher adsorption capacity of PVC for TCS } \\
\text { - joint toxicity of PVC } 1 \mu \mathrm{m} \text { most significant }(\mathrm{PE}<\mathrm{PVC}< \\
\text { PS }<\text { PVC1 } \mu \mathrm{m} \text { ) because of the minimum particle size } \\
\text { - antagonist interactions }\end{array}$ & 57 \\
\hline $\begin{array}{l}\text { Raphidocelis } \\
\text { subcapitata }\end{array}$ & $\begin{array}{l}\text { fresh } \\
\text { water }\end{array}$ & $\mathrm{PE}$ & & $\begin{array}{c}63-75 \\
\mu \mathrm{m}\end{array}$ & $130 \mathrm{mg} / \mathrm{L}$ & $5 \mathrm{~d}$ & & $\begin{array}{c}\text { - higher growth with microplastics } \\
\text { - hypothesis: microplastics could serve as substrates for } \\
\text { growth } \\
\end{array}$ & 55 \\
\hline $\begin{array}{l}\text { Chlamydomonas } \\
\text { reinhardtii }\end{array}$ & $\begin{array}{l}\text { fresh } \\
\text { water }\end{array}$ & PS & & $<100 \mathrm{~nm}$ & $\begin{array}{l}50 \mathrm{mg} / \mathrm{L} \\
\text { (up to } 100 \\
\mathrm{mg} / \mathrm{L} \text { for } \\
\text { toxicity }\end{array}$ & $72 \mathrm{~h}$ & & $\begin{array}{l}\text { - trophic transfer study with } 4 \text { levels } \\
\text { - adsorption of nanoplastics on algae surface and transfer to } \\
\text { higher trophic level through diet with toxicity } \\
\text { - no toxicity to microalgae (through chlorophyll fluorescence } \\
\text { evaluation) }\end{array}$ & 74 \\
\hline
\end{tabular}




\begin{tabular}{|c|c|c|c|c|c|c|c|c|c|}
\hline & & & & & $\begin{array}{l}\text { assessmen } \\
\text { t) }\end{array}$ & & & & \\
\hline $\begin{array}{c}\text { Chlorella } \\
\text { pyrenoidosa }\end{array}$ & $\begin{array}{l}\text { fresh } \\
\text { water } \\
\text { (BG-11 } \\
\text { medium) }\end{array}$ & PS & & $0.1,1 \mu \mathrm{m}$ & $\begin{array}{c}10,50, \\
100 \mathrm{mg} / \mathrm{L}\end{array}$ & $\begin{array}{l}30 \mathrm{~d} \\
\log \text { and } \\
\text { stationary } \\
\text { phases }\end{array}$ & & $\begin{array}{c}\text { - dose dependent growth inhibition } \\
\text { - decrease of photosynthetic activity, structural damages } \\
\text { - defense mechanisms: cell wall thickening, homo and hetero } \\
\text { aggregation when in stationary growth phase }\end{array}$ & 35 \\
\hline Tetraselmis chuii & $\begin{array}{l}\text { seawater } \\
\quad(\mathrm{f} / 2 \\
\text { medium })\end{array}$ & $? ?$ & & $1-5 \mu \mathrm{m}$ & $\begin{array}{c}0.75 \text { to } 48 \\
\mathrm{mg} / \mathrm{L}\end{array}$ & $\begin{array}{c}96 \mathrm{~h}, \\
\text { log phase }\end{array}$ & $\begin{array}{l}\text { procaina } \\
\text { mide, } \\
\text { doxycyc } \\
\text { line } \\
\text { (pharma } \\
\text { ceuticals } \\
\text { ): } 4 \text { to } \\
256 \\
\mathrm{mg} / \mathrm{L}\end{array}$ & $\begin{array}{l}\text { - plastics alone no effects on growth rate up to } 41.5 \mathrm{mg} / \mathrm{L} \\
\text { - chlorophyll significantly reduced at } 0.9 \text { and } 2.1 \mathrm{mg} / \mathrm{L} \\
\text { plastics, but not at higher concentrations } \\
\text { - EC } 50 \text { (growth rate and chlorophyll, respectively): } 104 \text { and } \\
143 \mathrm{mg} / \mathrm{L} \text { for procainamide alone; } 125 \text { and } 31 \mathrm{mg} / \mathrm{L} \text { for } \\
\text { procainamide + plastics; } 22 \text { and } 14 \mathrm{mg} / \mathrm{L} \text { for doxycycline } \\
\text { alone; } 11 \text { and } 7 \mathrm{mg} / \mathrm{L} \text { for + plastics } \\
\text { - plastics-pharmaceutical mixtures more toxic than the } \\
\text { pharmaceuticals alone }\end{array}$ & 52 \\
\hline $\begin{array}{l}\text { Microcystis } \\
\text { aeruginosa }\end{array}$ & $\begin{array}{l}\text { fresh } \\
\text { water } \\
\text { (BG-11 } \\
\text { medium) }\end{array}$ & PS & $-\mathrm{NH}_{2}$ & $200 \mathrm{~nm}$ & $\begin{array}{l}\text { up to } 20 \\
\mathrm{mg} / \mathrm{L}\end{array}$ & $\begin{array}{c}96 \mathrm{~h}, \\
\text { log phase }\end{array}$ & $\begin{array}{l}\text { glyphos } \\
\text { ate ( up } \\
\text { to } 7 \\
\mathrm{mg} / \mathrm{L})\end{array}$ & $\begin{array}{c}\text { - } 5 \mathrm{mg} / \mathrm{L} \text { glyphosate --> strong inhibitory effect while } 5 \\
\mathrm{mg} / \mathrm{L} \text { nanoPS- } \mathrm{NH}_{2} \text { had no apparent effect on the growth } \\
\text { - chlorophyll decreased at } 10 \mathrm{mg} / \mathrm{L} \text { after } 96 \mathrm{~h} \\
\text { - nanoPS- } \mathrm{NH}_{2} \text { combined with glyphosate showed } \\
\text { antagonistic effects (adsorption) } \\
\text { - glyphosate presence enhanced dispersion stability }\end{array}$ & 73 \\
\hline $\begin{array}{l}\text { Dunaliella } \\
\text { tertiolecta }\end{array}$ & $\begin{array}{l}\text { seawater } \\
\text { (natural) }\end{array}$ & PS & $\begin{array}{c}-\mathrm{COOH} \\
-\mathrm{NH}_{2}\end{array}$ & $\begin{array}{l}40 \mathrm{~nm} \\
50 \mathrm{~nm}\end{array}$ & $\begin{array}{l}\text { up to } 50 \\
\mathrm{mg} / \mathrm{L}\end{array}$ & $72 \mathrm{~h}$ & & $\begin{array}{c}\text { - negatively charged particles lead to agglomeration }>1 \mu \mathrm{m} \\
\text { with no toxicity } \& \text { adsorption on algae surface }(\text { i.e. } \text { possible } \\
\text { trophic transfer) } \\
\text { - positively charged particles showed no agglomeration, } \\
\text { inhibition of algal growth }\left(\mathrm{EC}_{50}=13 \mathrm{mg} / \mathrm{L}\right)\end{array}$ & 33 \\
\hline $\begin{array}{l}\text { Tisochrysis lutea } \\
\text { Heterocapsa } \\
\text { triquetra } \\
\text { Chaetoceros } \\
\text { neogracile }\end{array}$ & $\begin{array}{l}\text { seawater } \\
\quad(\mathrm{f} / 2 \\
\text { medium })\end{array}$ & PS & & $2 \mu \mathrm{m}$ & $\begin{array}{l}4 \mu \mathrm{g} / \mathrm{L} \\
(\text { and } 40 \\
\mu \mathrm{g} / \mathrm{L})\end{array}$ & $\begin{array}{l}\text { over one } \\
\text { culture } \\
\text { cycle, } \\
\text { log and } \\
\text { stationary } \\
\text { phases }\end{array}$ & & $\begin{array}{c}\text { - hetero-aggregation for } C \text {. neogracile during stationary } \\
\text { growth phase } \\
\text { - high adsorption with } T \text {. lutea and } H \text {. triquetra, increasing } \\
\text { with the age of the culture for both species } \\
\text { - no effects of PS on microalgal growth and chlorophyll } \\
\text { fluorescence }\end{array}$ & 51 \\
\hline
\end{tabular}




\begin{tabular}{|c|c|c|c|c|c|c|c|c|c|}
\hline $\begin{array}{l}\text { Raphidocelis } \\
\text { subcapitata }\end{array}$ & $\begin{array}{l}\text { fresh } \\
\text { water } \\
\text { (ISO } \\
\text { medium) }\end{array}$ & PS & $\begin{array}{l}-\mathrm{COOH} \\
-\mathrm{NH}_{2} \\
- \text { non } \\
\text { function } \\
\text { alized }\end{array}$ & $\begin{array}{l}0.11 \mu \mathrm{m} \\
0.02 \mu \mathrm{m} \\
0.05 \text { to } \\
0.5 \mu \mathrm{m}\end{array}$ & $10 \mathrm{mg} / \mathrm{L}$ & $2 \mathrm{~h}$ & & $\begin{array}{l}\text { - influence of surface functionalization and water hardness } \\
\qquad\left(\mathrm{Ca}^{2+}\right) \text { on nanoparticle behavior } \\
\text { - positively and neutral nanoparticles strongly attached to } \\
\text { algae surface ( } v s \text {. negatively charged) } \\
\text { - medium hardness and particle concentration influenced } \\
\text { interactions between nanoparticles and algae }\end{array}$ & 59 \\
\hline $\begin{array}{l}\text { Skeletonema } \\
\text { costatum }\end{array}$ & seawater & PVC & & $\begin{array}{l}1 \mu \mathrm{m}, \\
1 \mathrm{~mm}\end{array}$ & $\begin{array}{l}\text { up to } 50 \\
\mathrm{mg} / \mathrm{L} \text {, up } \\
\text { to } 2000 \\
\mathrm{mg} / \mathrm{L} \text { for } \\
\text { mesoPVC }\end{array}$ & $\begin{array}{c}96 \mathrm{~h}, \\
\text { log phase }\end{array}$ & & $\begin{array}{c}\text { - growth inhibition up to } 39.7 \% \text { after } 96 \mathrm{~h} \text { and inhibition of } \\
\text { photosynthesis for microplastics } \\
\text { - no toxicity for mesoPVC } \\
\text { - shading effect was not a reason for toxicity } \\
\text { - adsorption }\end{array}$ & 44 \\
\hline $\begin{array}{l}\text { Chlamydomas } \\
\text { reinhardtii }\end{array}$ & $\begin{array}{c}\text { fresh } \\
\text { water } \\
\text { (TAP } \\
\text { medium) }\end{array}$ & $\begin{array}{c}\text { PP } \\
\text { HDPE }\end{array}$ & & $\begin{array}{l}400 \mu \mathrm{m}- \\
1000 \mu \mathrm{m}\end{array}$ & $\begin{array}{l}1000 \\
\mathrm{mg} / \mathrm{L}\end{array}$ & $\begin{array}{c}78 \mathrm{~d}, \\
\text { log phase }\end{array}$ & & $\begin{array}{c}\text { - no impact on algae growth in the first days } \\
\text { - no change in stress response gene expression after } 78 \mathrm{~d} \\
\text { - after } 20 \mathrm{~d} \text { with PP higher production of EPS leading to } \\
\text { hetero-aggregation } \\
\text { - increased gene expression for sugar biosynthesis (mostly } \\
\text { for HDPE) } \\
\text { - both plastics were colonized }\end{array}$ & 61 \\
\hline $\begin{array}{l}\text { Thalassiosira } \\
\text { pseudonana } \\
\text { Dunaliella } \\
\text { tertiolecta } \\
\text { Chorella vulgaris }\end{array}$ & $\begin{array}{l}\text { seawater } \\
\quad(\mathrm{f} / 2 \\
\text { medium) } \\
\quad \text { fresh } \\
\text { water } \\
\text { (BG-11 } \\
\text { medium) }\end{array}$ & PS & $\begin{array}{l}-\mathrm{COOH} \\
\text { and } \\
\text { uncharg } \\
\text { ed }\end{array}$ & $\begin{array}{l}0.05,0.5 \\
\quad 6 \mu \mathrm{m}\end{array}$ & $\begin{array}{c}25,250 \\
\mathrm{mg} / \mathrm{L}\end{array}$ & $\begin{array}{c}72 \mathrm{~h}, \\
\text { log phase }\end{array}$ & & $\begin{array}{l}\text { - no effect on photosynthesis } \\
\text { - growth decreased by up to } 45 \% \text { by uncharged particles only } \\
\text { at } 250 \mathrm{mg} / \mathrm{L} \\
\text { - size dependent effect (the smaller the more toxic) }\end{array}$ & 43 \\
\hline Tetraselmis chuii & seawater & $\mathrm{PE}$ & & $1-5 \mu \mathrm{m}$ & $\begin{array}{l}0.046 \text { to } \\
1.472 \\
\mathrm{mg} / \mathrm{L}\end{array}$ & $\begin{array}{c}96 \mathrm{~h}, \\
\text { log phase }\end{array}$ & $\begin{array}{c}\mathrm{Cu} \\
(0.02 \text { to } \\
0.64 \\
\mathrm{mg} / \mathrm{L})\end{array}$ & $\begin{array}{l}\text { - no significant effects of plastics on algal growth } \\
\text { - } \mathrm{Cu} \text { alone significantly decreased the growth }\left(\mathrm{EC}_{50}=0.139\right. \\
\mathrm{mg} / \mathrm{L}) \\
-\mathrm{EC}_{50} \mathrm{Cu}+\mathrm{PE}=0.145 \mathrm{mg} / \mathrm{L} \\
\text { - no significant differences between the toxicity curves of } \mathrm{Cu} \\
\text { in the presence and absence of } \mathrm{PE}\end{array}$ & 54 \\
\hline $\begin{array}{c}\text { Scenedesmus } \\
\text { obliquus }\end{array}$ & $\begin{array}{l}\text { fresh } \\
\text { water } \\
\text { (WC } \\
\text { medium) }\end{array}$ & PS & $-\mathrm{COOH}$ & $70 \mathrm{~nm}$ & $\begin{array}{l}\text { up to } \\
1100 \\
\mathrm{mg} / \mathrm{L}\end{array}$ & $\begin{array}{c}72 \mathrm{~h}, \\
\text { log phase }\end{array}$ & & $\begin{array}{l}\text { - nanoPS reduced the growth }(-2.5 \%) \text { and chlorophyll } \\
\text { concentration in algae at the highest concentration } \\
\text { - trophic chain experiment with Daphnia magna }\end{array}$ & 38 \\
\hline
\end{tabular}




\begin{tabular}{|c|c|c|c|c|c|c|c|c|}
\hline $\begin{array}{c}\text { Raphidocelis } \\
\text { subcapitata }\end{array}$ & $\begin{array}{l}\text { algal } \\
\text { growth } \\
\text { medium }\end{array}$ & $\begin{array}{l}\text { PS-PEI } \\
\text { (polyethyl } \\
\text { eneimine } \\
\text { polystyren } \\
\text { e) } \\
\end{array}$ & & $\begin{array}{l}55 \mathrm{~nm}, \\
110 \mathrm{~nm}\end{array}$ & $\begin{array}{c}0.1 \text { to } 1 \\
\mathrm{mg} / \mathrm{L}\end{array}$ & $72 \mathrm{~h}$ & $\begin{array}{c}\text { - trophic chain experiment } \\
\text { - toxicity from } 0.40 \mathrm{mg} / \mathrm{L} \text { to } 416.5 \mathrm{mg} / \mathrm{L} \text { according to } \\
\text { considered species: } R . \text { subcapitata } \geq D . \text { magna }>\text { T. platyurus } \\
>V . \text { fischeri. } \\
-\mathrm{EC}_{50}=0.5 \mathrm{mg} / \mathrm{L}\end{array}$ & 40 \\
\hline $\begin{array}{l}\text { Amphora sp } \\
\text { Ankistrodesmus } \\
\quad \text { angustus } \\
\text { Phaeodactylum } \\
\text { tricornutum }\end{array}$ & $\begin{array}{l}\text { seawater } \\
\text { (artificial) }\end{array}$ & PS & & $23 \mathrm{~nm}$ & $\begin{array}{c}10,100 \\
\mu \mathrm{g} / \mathrm{L}\end{array}$ & $\begin{array}{c}13 \mathrm{~d}, \\
\text { stationary } \\
\text { phase }\end{array}$ & $\begin{array}{l}\text { - PS induced acceleration in Amphora sp. EPS assembly } \\
\text { - after } 72 \mathrm{~h} \text { PS-EPS aggregation reached equilibrium, } \\
\text { forming microscopic gels of } 4-6 \mu \mathrm{m} \text { in size } \\
\text { - PS only cause moderate assembly kinetic acceleration for } A \text {. } \\
\text { angustus and } P \text {. tricornutum EPS samples } \\
\text { - effects of PS on EPS assembly kinetics mainly depended on } \\
\text { the hydrophobic interactions of PS with EPS polymers }\end{array}$ & 70 \\
\hline $\begin{array}{l}\text { Scenedesmus } \\
\text { Chlorella }\end{array}$ & $\begin{array}{c}\text { fresh } \\
\text { water } \\
\text { (Alga-gro } \\
\text { medium) }\end{array}$ & PS & $\begin{array}{c}-\mathrm{NH}_{2} \\
-\mathrm{COOH}\end{array}$ & $20 \mathrm{~nm}$ & $\begin{array}{c}80 \text { to } 800 \\
\mathrm{mg} / \mathrm{L}\end{array}$ & $2 \mathrm{~h}$ & $\begin{array}{c}\text { - preferential adsorption of positively charge PS (vs. } \\
\text { negatively charged because of the interactions between } \\
\text { plastic beads and cellulose components) } \\
\text { - adsorption led to decreased photosynthesis (physical } \\
\text { blockage of light and air?) } \\
\text { - adsorption led also to increased ROS production }\end{array}$ & 39 \\
\hline \multicolumn{9}{|c|}{ Macrophytes } \\
\hline Lemna minor & $\begin{array}{l}\text { hydropon } \\
\text { ics, } \\
\text { Steinberg } \\
\text { medium }\end{array}$ & $\begin{array}{l}\text { PE, } \\
\text { pristine } \\
\text { and aged } \\
\text { in } \\
\text { wastewate } \\
\quad \mathrm{r} \\
\end{array}$ & & $\begin{array}{l}140 \pm 80 \\
\mu \mathrm{m}, \max \\
1000 \mu \mathrm{m}\end{array}$ & $100 \mathrm{mg} / \mathrm{L}$ & $7 \mathrm{~d}$ & $\begin{array}{c}\text { - pristine particles: decreased root growth } v s \text {. aged particles: } \\
\text { root growth decreased or no effect, depending on the aging } \\
\text { medium } \\
\text { - visible coating for aged beads, not characterized } \\
\text { - adsorption of co-contaminant: possible in case of aged } \\
\text { particles, not characterized }\end{array}$ & 90 \\
\hline $\begin{array}{l}\text { Myriophyllum } \\
\text { spicatum, } \\
\text { Elodea sp. }\end{array}$ & $\begin{array}{l}\text { sediment } \\
\text { amended } \\
\text { with } \\
\text { plastics + } \\
\text { Smart } \\
\text { and } \\
\text { Barko } \\
\text { medium }\end{array}$ & PS & & $\begin{array}{l}50 \text { to } 190 \\
\text { nm, } \\
20 \text { to } \\
500 \mu \mathrm{m}\end{array}$ & $\begin{array}{l}0.1,0.3,1 \\
3 \text { and } \\
10 \% \\
\text { sediment } \\
\text { DW }\end{array}$ & $21 \mathrm{~d}$ & $\begin{array}{l}\text { - increased root biomass for both macrophytes for NPs } \\
\text { - decreased shoot length for } M \text {. spicatum for NPs } \\
\text { - no effect on biomass, relative growth rate, shoot length for } \\
\text { both macrophytes, except a decreased shoot length for } M \text {. } \\
\text { spicatum for MPs }\end{array}$ & 91 \\
\hline
\end{tabular}




\begin{tabular}{|c|c|c|c|c|c|c|c|c|c|}
\hline Lemna minor & $\begin{array}{l}\text { hydropon } \\
\text { ics, } \\
\text { Steinberg } \\
\text { medium }\end{array}$ & $\begin{array}{l}\text { PE, sharp } \\
\text { and } \\
\text { smooth } \\
\text { surface }\end{array}$ & & $\begin{array}{l}30-600 \\
\mu \mathrm{m}\end{array}$ & $\begin{array}{l}10 \text { to } 100 \\
\mathrm{mg} / \mathrm{L}\end{array}$ & $7 \mathrm{~d}$ & & $\begin{array}{l}\text { - no effect on specific leaf growth rate and on photosynthetic } \\
\text { pigments } \\
\text { - decrease in root growth due to mechanical blocking } \\
\text { - reduced root cell viability for sharp particles }\end{array}$ & 89 \\
\hline \multicolumn{10}{|c|}{ Terrestrial plants } \\
\hline Vigna radiata & soil & PS & & $20 \mathrm{~nm}$ & $\begin{array}{l}0,10,100 \\
\mathrm{mg} / \mathrm{kg}\end{array}$ & $10 \mathrm{~d}$ & & $\begin{array}{l}\text { - decreased root growth } \\
\text { - particle accumulation in leaves } \\
\text { - trophic transfer to snails }\end{array}$ & 121 \\
\hline Oryza sativa & $\begin{array}{l}\text { hydropon } \\
\text { ics }\end{array}$ & PS, PTFE & & $10 \mu \mathrm{m}$ & $\begin{array}{l}0.04,0.1 \\
0.2 \mathrm{~g} / \mathrm{L}\end{array}$ & $10 \mathrm{~d}$ & $\begin{array}{l}\text { As } \\
1.6,3.2 \\
4 \mathrm{mg} / \mathrm{L}\end{array}$ & $\begin{array}{l}\text { - PS and PTFE affected transpiration and stomata inhibiting } \\
\text { root vigor, lowering photosynthesis and decreasing biomass } \\
\text { - As relatively more toxic than microplastics } \\
\text { - low doses of plastic reduced the toxicity induced by As but } \\
\text { higher doses increased the negative effects }\end{array}$ & 112 \\
\hline Allium cepa & $\begin{array}{l}\text { germinati } \\
\text { on test } \\
\text { and early } \\
\text { developp } \\
\text { ment }\end{array}$ & PS & & $83 \mathrm{~nm}$ & $\begin{array}{l}0.01,0.1 \\
1 \mathrm{~g} / \mathrm{L}\end{array}$ & $72 \mathrm{~h}$ & & $\begin{array}{c}\text { - dose dependent decrease of root length } \\
\text { - decrease of mitotic index at } 0 \text {, and } 1 \mathrm{~g} / \mathrm{L} \\
\text { - frequency of abnormal metaphases and ana/telophases } \\
\text { increased with the dose } \\
\text { - cytological abnormalities at all concentrations } \\
\text { - non monotonic oxidative stress } \\
\text { - dose-dependent } \mathrm{H}_{2} \mathrm{O}_{2} \text { production in the root epidermis, } \\
\text { cortical cylinder and vascular tissues } \\
\text { - internalization of PS by cells and accumulation in vacuoles, } \\
\text { cytoplasm and less often in the nucleus } \\
\text { - accumulation of high density bodies in the cytoplasm }\end{array}$ & 115 \\
\hline Triticum aestivum & $\begin{array}{l}\text { hydropon } \\
\text { ics }\end{array}$ & PS, PTFE & & $87 \mathrm{~nm}$ & $\begin{array}{l}0,10 \\
\mathrm{mg} / \mathrm{L}\end{array}$ & 3 weeks & $\begin{array}{l}\mathrm{Cd} \\
0,20 \\
\mu \mathrm{M}\end{array}$ & $\begin{array}{l}\text { - presence of PS reduced Cd contents in leaves and alleviated } \\
\text { Cd toxicity } \\
\text { - alteration in the morphology of root tips } \\
\text { - increase in the activity of CAT and POD vs decrease in } \\
\text { SOD } \\
\text { - reduction in Fe, Mn and Cu concentrations } \\
\text { - PS increase MDA in leaves but PS-Cd showed less MDA } \\
\text { than Cd alone } \\
\text { - PS increased carbohydrate and aminoacid metabolisms and } \\
\text { promoted the formation of long lived radicals }\end{array}$ & 117 \\
\hline $\begin{array}{l}\text { Arabidopsis } \\
\text { thaliana }\end{array}$ & $\begin{array}{l}\text { agar, } \\
\text { hydropon } \\
\text { ics, } \\
\text { soil }\end{array}$ & PS & $\begin{array}{l}-\mathrm{SO}_{3} \mathrm{H} \\
-\mathrm{COOH} \\
-\mathrm{NH}_{2} \\
\end{array}$ & $\begin{array}{l}55,71 \\
120,220 \\
\quad \mathrm{~nm}\end{array}$ & $\begin{array}{l}\text { agar : } 10 \\
50,100 \\
\mu \mathrm{g} / \mathrm{L}\end{array}$ & $\begin{array}{c}\text { agar: } \\
10 \mathrm{~d} \\
\text { hydroponi } \\
\text { cs : }\end{array}$ & & $\begin{array}{l}\text { - agar: decrease of root growth (dose and charge dependent }+ \\
\text { overregulation of peroxidases and plant pathogen genes }+\end{array}$ & 107 \\
\hline
\end{tabular}




\begin{tabular}{|c|c|c|c|c|c|c|c|}
\hline & & & & $\begin{array}{l}\text { hydroponi } \\
\text { cs: } 50 \\
\mu \mathrm{g} / \mathrm{L} \\
\text { soil }: 0.3 \\
1.0 \mathrm{~g} / \mathrm{kg}\end{array}$ & $\begin{array}{c}7 \mathrm{~d} \\
\text { soil : } \\
7 \text { weeks }\end{array}$ & $\begin{array}{c}\mathrm{H}_{2} \mathrm{O}_{2} \text { accumulation in the root tips and root maturation zone } \\
+ \text { accumulation and toxicity of PS- } \mathrm{NH}_{2}>>\mathrm{PS}-\mathrm{SO}_{3} \mathrm{H}+ \\
\text { alterations in the morphology of root maturation zone } \\
\text { - hydroponics: positively charged mainly accumulated in } \\
\text { stele and maturation zone of roots + negatively charged } \\
\text { mainly accumulated in root epidermis and root hairs + } \\
\text { increase in exudation of oxalate PS- } \mathrm{NH}_{2}>>\mathrm{PS}-\mathrm{SO}_{3} \mathrm{H}+ \\
\text { accumulation in the epidermal cells and catheter of the xylem } \\
\text { of roots for } 120 \mathrm{~nm} \text { negatively charged } \\
\text { - soil: decrease of biomass and chlorophyll contents at high } \\
\text { dose }\end{array}$ & \\
\hline $\begin{array}{l}\text { Arabidopsis } \\
\text { thaliana, } \\
\text { Triticum } \\
\text { aestivum }\end{array}$ & $\begin{array}{l}\text { Germinati } \\
\text { on test } \\
\text { and early } \\
\text { developp } \\
\text { ment }\end{array}$ & PS & $\begin{array}{c}40 \mathrm{~nm} \\
1 \mu \mathrm{m}\end{array}$ & $0.029 \mathrm{~g} / \mathrm{L}$ & \begin{tabular}{|} 
T. \\
aestivum: \\
$5 \mathrm{~d}$ \\
A. \\
thaliana: \\
$12 \mathrm{~d}$
\end{tabular} & $\begin{array}{l}\text { - accumulation in the root surface, especially root tip but no } \\
\text { evidence of internal uptake } \\
\text { - no effects on seed germination, root length or plant height }\end{array}$ & 118 \\
\hline Lolium perenne & $\begin{array}{l}\text { soil } \\
\text { (+earthw } \\
\text { orms })\end{array}$ & $\begin{array}{l}\text { HDPE, } \\
\text { PLA, } \\
\text { acrylic } \\
\text { and nylon } \\
\text { fibers }\end{array}$ & $\begin{array}{c}\text { HDPE: } \\
102.6 \mu \mathrm{m}, \\
\text { PLA } \\
\text { fibers: } \\
65.6 \mu \mathrm{m}, \\
>2 \mathrm{~mm}-16 \\
\mathrm{~mm}\end{array}$ & $\begin{array}{c}0.1 \% \\
\text { particles } \\
\text { w/w, } \\
0.001 \% \\
\text { fibers } \mathrm{w} / \mathrm{w}\end{array}$ & $30 \mathrm{~d}$ & $\begin{array}{l}\text { - reduced germination } \\
\text { - PLA decreased shoot length } \\
\text { - HDPE increased root biomass }\end{array}$ & 141 \\
\hline Lepidium sativum & $\begin{array}{l}\text { germinati } \\
\text { on test }\end{array}$ & $\begin{array}{c}\text { not } \\
\text { specified }\end{array}$ & $\begin{array}{c}50,500 \\
\text { and } 4800 \\
\mathrm{~nm}\end{array}$ & $\begin{array}{l}10^{3}, 10^{4} \\
10^{5}, 10^{6} \\
\quad, 10^{7} \\
\text { particles/ } \\
\quad \mathrm{mL}\end{array}$ & $72 \mathrm{~h}$ & $\begin{array}{l}\text { - dose and size dependent delay on germination } \\
\text { - reduced root growth after } 24 \mathrm{~h} \text { in } 50 \mathrm{~nm} \text { treatment and } \\
\text { increase in } 500 \mathrm{~nm} \text { but no differences at } 48 \text { and } 72 \mathrm{~h} \\
\text { - accumulation of particles in the testa of seeds and in the } \\
\text { radicles, shoots, leaves and specially root hairs of seedlings. }\end{array}$ & 103 \\
\hline Allium fistulosum & soil & $\begin{array}{l}\text { PA, PES } \\
\text { fibers, } \\
\text { PEHD, } \\
\text { PP, PS, } \\
\text { PET }\end{array}$ & $\begin{array}{c}\text { PA: } \\
\text { 15-20 } \mu \mathrm{m} \text {, } \\
\text { PES } \\
\text { fibers: } \\
\text { length } \\
5000 \mu \mathrm{m} / \\
\text { diameter } 8 \\
\mu \mathrm{m}, \\
\text { PEHD: } \\
643 \mu \mathrm{m}, \\
\end{array}$ & $\begin{array}{c}2 \% \mathrm{w} / \mathrm{w} \\
\text { particle } \\
0.2 \% \\
\text { w/w fibers }\end{array}$ & $\begin{array}{c}1.5 \\
\text { months } \\
\text { (after } 1.5 \\
\text { month soil } \\
\text { incubation } \\
\text { ) }\end{array}$ & $\begin{array}{c}\text { - PES and PS increased root biomass } \\
\text { - PA decreased root/leaf dry mass, PES, PET, PP, PEHD and } \\
\text { PS increased it } \\
\text { - increase in total root length, decrease in root diameter and } \\
\text { decrease in total root area } \\
\text { - PA decreased root tissue density, PS and PES increased it } \\
\text { - PES and PP increased mycorrhiza root colonization, PET } \\
\text { decreased it }\end{array}$ & 142 \\
\hline
\end{tabular}




\begin{tabular}{|c|c|c|c|c|c|c|c|}
\hline & & & $\begin{array}{c}\text { PET: } \\
376 \mu \mathrm{m}, \\
\text { PP: } \\
816 \mu \mathrm{m} \\
\text { PS: } \\
754 \mu \mathrm{m}\end{array}$ & & & $\begin{array}{c}\text { - alterations in dry weight related to water contents (PA } \\
\text { decrease in dry biomass with increase in water content, the } \\
\text { opposite for PES) } \\
\text { - PA decreased C:N ratios and PES increased it } \\
\text { - PA increased aboveground leaf and PES increased } \\
\text { belowground bulb } \\
\text { - toxicity(fibers }>>\text { microplastics) (PA }>\text { PEHD, PP, PS and } \\
\text { PET) }\end{array}$ & \\
\hline Allium сера & $\begin{array}{l}\text { hydropon } \\
\text { ics }\end{array}$ & PS & $100 \mathrm{~nm}$ & $\begin{array}{l}5,10,15 \\
20,25 \\
\mu \mathrm{g} / \mathrm{mL}\end{array}$ & $\begin{array}{c}3,6,12 \\
24 \mathrm{~h}\end{array}$ & $\begin{array}{c}\text { - dose response decrease of mitotic index and increase in } \\
\text { chromosome aberrations } \\
\text { - decrease of root growth }\end{array}$ & 119 \\
\hline Vicia faba & $\begin{array}{l}\text { germinati } \\
\text { on test }\end{array}$ & PS & $\begin{array}{c}100 \mathrm{~nm} \\
5 \mu \mathrm{m}\end{array}$ & $\begin{array}{c}10,50, \\
100 \mathrm{mg} / \mathrm{L}\end{array}$ & $48 \mathrm{~h}$ & $\begin{array}{c}\text { - exposure to } 5 \mu \mathrm{m} \text { particles decreased root length and } \\
\text { relative root elongation at } 50 \text { and } 100 \mathrm{mg} / \mathrm{L} \\
\text { - } 100 \mathrm{~nm} \text { decreased relative root elongation at } 100 \mathrm{mg} / \mathrm{L} \\
\text { - } 5 \mu \mathrm{m} \text { treatment at } 100 \mathrm{mg} / \mathrm{L} \text { and all } 100 \mathrm{~nm} \text { treatments } \\
\text { decreased root weigh } \\
\text { - higher uptake of } 100 \mathrm{~nm} \text { particles than } 5 \mu \mathrm{m} \text { ones } \\
\text { - SOD increased in all treatments. CAT activity showed } \\
\text { significant change in nearly all treatments } \\
\text { - no effect on MDA for the } 5 \mu \mathrm{m} \text { treatments, decrease in the } \\
\text { low dose of } 100 \mathrm{~nm} \text { and increase at high dose. } \\
\text { - for } 100 \mathrm{~nm} \text {, dose dependent increase in micronucleus } \\
\text { frequency } \\
\text { - genotoxic and oxidative damage (nano>>micro) }\end{array}$ & 104 \\
\hline $\begin{array}{c}\text { Plantago } \\
\text { lanceolata }\end{array}$ & $\begin{array}{c}\text { artificial } \\
\text { soil } \\
\text { (quartz, } \\
\text { sand,ver } \\
\text { miculite) }\end{array}$ & EPDM & $\begin{array}{c}0.5-2.5 \\
\mathrm{~mm}\end{array}$ & $\begin{array}{l}0,0.25 \\
0.5,1,2,4 \\
8,16,32 \\
64 \% \mathrm{v} / \mathrm{v}\end{array}$ & 7 weeks & $\begin{array}{l}\text { - reduced plant survival } \\
\text { - non monotonic response in total biomass } \\
\text { - decrease in root weight }\end{array}$ & 101 \\
\hline $\begin{array}{c}\text { Alopecurus } \\
\text { pratensis, } \\
\text { Festuca } \\
\text { guestfalica, } \\
\text { Lolium perenne, } \\
\text { Galium album, } \\
\text { Leucanthemum } \\
\text { ircutianum, } \\
\text { Leucanthemum } \\
\text { vulgare, } \\
\end{array}$ & $\begin{array}{l}\text { artificial } \\
\text { soil } \\
\text { (mixture } \\
\text { sand and } \\
\text { vermiculi } \\
\text { te) }\end{array}$ & EPDM & $\begin{array}{c}0.5-2.5 \\
\mathrm{~mm}\end{array}$ & $5 \% \mathrm{v} / \mathrm{v}$ & 1 week & $\begin{array}{l}\text { - reduction of aboveground biomass and root weight and } \\
\text { increase in root length but reduced weight } \\
\text { - reduced competitive interactions }\end{array}$ & 101 \\
\hline
\end{tabular}




\begin{tabular}{|c|c|c|c|c|c|c|c|}
\hline \multicolumn{8}{|l|}{$\begin{array}{c}\text { Prunella vulgaris, } \\
\text { Daucus carota }\end{array}$} \\
\hline Triticum aestivum & $\begin{array}{c}\text { Germinati } \\
\text { on test } \\
+ \\
\text { hydropon } \\
\text { ics }\end{array}$ & PS & $100 \mathrm{~nm}$ & $\begin{array}{l}0.01,0.1 \\
1,10 \\
\mathrm{mg} / \mathrm{L}\end{array}$ & $\begin{array}{l}5 \mathrm{~d} \\
21 \mathrm{~d}\end{array}$ & $\begin{array}{c}\text { - germination rate not affected } \\
\text { - improved seed vigor at } 0.01 \text { and } 10 \mathrm{mg} / \mathrm{L} \\
\text { - increase in root elongation and water imbibition } \\
\text { - increase in chlorophyll content at } 0.1 \text { and } 1 \mathrm{mg} / \mathrm{L} \text { and of } \\
\text { shoot biomass at } 0.01 \text { and } 0.1 \mathrm{mg} / \mathrm{L} \\
\text { - root biomass increased at } 0.01,0.1 \text { and } 1 \mathrm{mg} / \mathrm{L} \text { but reduced } \\
\text { shoot to root ratio } \\
\text { - root length, average diameter, surface area and root volume } \\
\text { increased at all doses except at } 10 \mathrm{mg} / \mathrm{L} \\
\text { - dose dependent increase in } \mathrm{C} \text { and } \mathrm{N} \text { contents } \\
\text { - reduction in micronutrient concentration }(\mathrm{Fe}, \mathrm{Mn}, \mathrm{Cu} \text { and } \\
\text { Zn) } \\
\text { - leaf metabolomic alterations (energy and aminoacid } \\
\text { metabolims) } \\
\text { - uptake and transport to the shoots }\end{array}$ & 117 \\
\hline $\begin{array}{l}\text { Thinopyrum } \\
\text { junceum, } \\
\text { Glaucium flavum }\end{array}$ & $\begin{array}{l}\text { germinati } \\
\text { on test }\end{array}$ & $\begin{array}{c}\text { non } \\
\text { biodegrad } \\
\text { able bags } \\
\text { (HDPE), } \\
\text { composta } \\
\text { ble bags: } \\
\text { non } \\
\text { exposed, } \\
\text { beach } \\
\text { exposed, } \\
\text { marine } \\
\text { exposed }\end{array}$ & $\begin{array}{c}\text { bag } \\
\text { leachates }\end{array}$ & $\begin{array}{l}\text { Water-to- } \\
\text { plastic } \\
\text { ratios of } \\
100,10 \\
\text { and } 5\end{array}$ & $\begin{array}{l}\text { until } \\
\text { germinati } \\
\text { on }\end{array}$ & $\begin{array}{l}\text { - alteration of germination time, radicle and hypocotyl length } \\
\text { and in bellow to aboveground length ratio depending on the } \\
\text { treatment and the plant species } \\
\text { - low concentration of leachates from marine-exposed bags } \\
\text { increased seed germination } \\
\text { - seedling anomalies in high concentration treatments }\end{array}$ & 110 \\
\hline Triticum aestivum & $\begin{array}{l}\text { soil } \\
\text { (+earthw } \\
\text { orms })\end{array}$ & $\begin{array}{c}\text { LDPE, } \\
\text { starch- } \\
\text { based } \\
\text { biodegrad } \\
\text { able }\end{array}$ & $\begin{array}{c}6.92 \mathrm{x} \\
6.10 \mathrm{~mm} \\
\text { for LDPE, } \\
6.98 \mathrm{x} \\
6.01 \mathrm{~mm} \\
\text { for Bio } \\
\text { and micro } \\
(12.5 \% \text { of } \\
1 \mathrm{~mm} \text { to } \\
500 \mu \mathrm{m},\end{array}$ & $1 \% \mathrm{w} / \mathrm{w}$ & $\begin{array}{l}2 \text { and } 4 \\
\text { months }\end{array}$ & $\begin{array}{c}\text { - changes in bacterial composition of the rhizosphere and } \\
\text { increase in emitted volatiles for the Bio treatment } \\
\text { - increase in } \mathrm{pH} \\
\text { - increase in } \mathrm{C}: \mathrm{N} \text { ratios (micro >>macro, LDPE>>Bio) }\end{array}$ & 108 \\
\hline
\end{tabular}




\begin{tabular}{|c|c|c|c|c|c|c|c|}
\hline & & & $\begin{array}{l}62.5 \% \text { of } \\
500 \mu \mathrm{m} \text { to } \\
250 \mu \mathrm{m} \\
\text { and } 25 \% \\
\text { of } 250 \mu \mathrm{m} \\
\text { to } 50 \mu \mathrm{m}) \\
\end{array}$ & & & & \\
\hline Murraya exotica & $\begin{array}{l}\text { hydropon } \\
\text { ics }\end{array}$ & $\begin{array}{l}\text { Styrene } \\
\text { maleic } \\
\text { anhydride }\end{array}$ & $12 \mathrm{~nm}$ & $\begin{array}{l}1.8,5.5 \\
18,55 \\
\mu \mathrm{g} / \mathrm{mL}\end{array}$ & $0-8 h$ & $\begin{array}{l}\text { - lignified epidermis is the the active tissue for the uptake } \\
\text { (apoplastic transport) } \\
\text { - translocation to the shoots through the sap }\end{array}$ & 120 \\
\hline Triticum aestivum & $\begin{array}{l}\text { soil } \\
\text { (+earthw } \\
\text { orms) }\end{array}$ & $\begin{array}{c}\text { LDPE, } \\
\text { starch- } \\
\text { based } \\
\text { biodegrad } \\
\text { able }\end{array}$ & $\begin{array}{c}6.92 \mathrm{x} \\
6.10 \mathrm{~mm} \\
\text { for LDPE, } \\
6.98 \mathrm{x} \\
6.01 \mathrm{~mm} \\
\text { for Bio } \\
\text { and micro } \\
(12.5 \% \text { of } \\
1 \mathrm{~mm} \text { to } \\
500 \mu \mathrm{m} \text {, } \\
62.5 \% \text { of } \\
500 \mu \mathrm{m} \text { to } \\
250 \mu \mathrm{m} \\
\text { and } 25 \% \\
\text { of } 250 \mu \mathrm{m} \\
\text { to } 50 \mu \mathrm{m})\end{array}$ & $1 \% \mathrm{w} / \mathrm{w}$ & $\begin{array}{l}2 \text { and } 4 \\
\text { months }\end{array}$ & $\begin{array}{c}\text { - decrease in root and total biomass, including fruit biomass } \\
\text { - increase in shoot to root ratio. In the Bio treatment, } \\
\text { decrease in number of leaves and leaf area } \\
\text { - thinner stems (negative effect micro>> macro plastics, } \\
\text { Bio >>LDPE) } \\
\text { - presence of earthworm alleviated toxicity }\end{array}$ & 143 \\
\hline $\begin{array}{c}\text { Brassica rapa } \\
\text { subsp. Chinensis, } \\
\text { Cucumis sativus, } \\
\text { Solanum } \\
\text { melongena, } \\
\text { Phaseolus } \\
\text { vulgaris, } \\
\text { Capsicum } \\
\text { annuum, } \\
\text { Raphanus sativus, } \\
\text { Solanum } \\
\text { lycopersicum }\end{array}$ & $\begin{array}{c}\text { survey } \\
\text { greenhou } \\
\text { ses, open } \\
\text { fields and } \\
\text { markets }\end{array}$ & $\begin{array}{l}\text { phatalate } \\
\text { esters }\end{array}$ & & $\begin{array}{c}0.26-2.53 \\
\mathrm{mg} / \mathrm{kg}\end{array}$ & & $\begin{array}{c}\text { - concentration of phtalates in vegetable leaves between } 0.95 \\
\text { and } 8.09 \mathrm{mg} / \mathrm{kg}\end{array}$ & 124 \\
\hline
\end{tabular}




\begin{tabular}{|c|c|c|c|c|c|c|c|}
\hline $\begin{array}{c}\text { Brassica rapa } \\
\text { Chinensis }\end{array}$ & soil & $\begin{array}{l}\text { film } \\
\text { mulch } \\
\text { PBAT }\end{array}$ & $\begin{array}{r}2 \times 2 \times \\
0.1 \mathrm{~cm}^{3}\end{array}$ & $\begin{array}{l}0,6 \% \\
(\mathrm{w} / \mathrm{w})\end{array}$ & 1 month & - non significant effects on plant growth & 111 \\
\hline $\begin{array}{l}\text { Gossypium } \\
\text { hirsutum }\end{array}$ & $\begin{array}{l}\text { field } \\
\text { study }\end{array}$ & $\begin{array}{c}\text { film } \\
\text { mulch } \\
\text { (polymer } \\
\text { not } \\
\text { specified) }\end{array}$ & $\begin{array}{c}0-25 \\
25-100 \\
100-200 \\
\mathrm{~cm}^{2}\end{array}$ & $\begin{array}{c}250,500 \\
1000 \\
1500 \\
2000 \\
\mathrm{~kg} / \mathrm{hm}^{2}\end{array}$ & 5 months & - reduction in the yield & 99 \\
\hline $\begin{array}{c}\text { Capsicum } \\
\text { annuum, } \\
\text { Cucumis sativus, } \\
\text { Brassica } \\
\text { oleracea, } \\
\text { Raphanus sativus, } \\
\text { Brassica } \\
\text { chinensis, } \\
\text { Lactuca sativa, } \\
\text { Chrysanthemum } \\
\text { coronarium, } \\
\text { Apium } \\
\text { graveolens, } \\
\text { Spinacia } \\
\text { oleracea, } \\
\text { Brassica juncea }\end{array}$ & $\begin{array}{l}\text { survey } \\
\text { greenhou } \\
\text { ses }\end{array}$ & $\begin{array}{l}\text { phatalate } \\
\text { esters }\end{array}$ & & $\begin{array}{l}2.56-2 . \\
23 \mathrm{mg} / \mathrm{kg}\end{array}$ & & $\begin{array}{l}\text { - concentration of phatalates in vegetables between } 0.51 \text { and } \\
7.16 \mathrm{mg} / \mathrm{kg} \\
\text { - accumulation in leaves and stems }\end{array}$ & 123 \\
\hline Allium сера & $\begin{array}{l}\text { germinati } \\
\text { on test }\end{array}$ & $\begin{array}{l}\text { nanocomp } \\
\text { osites of } \\
\text { PLA and } \\
\text { nanoclays }\end{array}$ & $\begin{array}{l}\text { leachates } \\
\text { from } \\
\text { compostin } \\
\quad \mathrm{g}\end{array}$ & $\begin{array}{c}50 \mathrm{~g} \\
\text { nanocomp } \\
\text { osite/ } \\
300 \mathrm{~g} \\
\text { compost, } \\
100 \mathrm{~g} \text { of } \\
\text { this } \\
\text { mixture in } \\
400 \mathrm{~mL} \\
\text { water }\end{array}$ & $\begin{array}{l}\text { until } 2 \mathrm{~cm} \\
\text { root }\end{array}$ & $\begin{array}{l}\text { - inhibition of cell division and mitosis } \\
\text { - higher frequency of chromosomal breaks and micronucleus }\end{array}$ & 109 \\
\hline Zea mays & soil & $\mathrm{PE}$ & $\begin{array}{l}\text { granules, } \\
\text { not } \\
\text { specified }\end{array}$ & $\begin{array}{c}0.83,1.67 \\
2.50,3.33 \\
\%\end{array}$ & 8 weeks & $\begin{array}{l}\text { - increase in height for low dose treatment decrease for the } \\
\text { others } \\
\text { - dose-dependent decrease of stem girth }\end{array}$ & 114 \\
\hline
\end{tabular}




\begin{tabular}{|c|c|c|c|c|c|c|c|}
\hline $\begin{array}{c}\text { Benincasa } \\
\text { hispida, } \\
\text { Cucumis sativus, } \\
\text { Cucurbita } \\
\text { moschata, } \\
\text { Brassica } \\
\text { parachinensis, } \\
\text { Momordica } \\
\text { charantia, } \\
\text { Lactuca sativa, } \\
\text { Capsicum } \\
\text { frutescens, } \\
\text { Luffa cylindrical, } \\
\text { Ipomoea } \\
\text { aquatica, } \\
\text { Lycopersicon } \\
\text { esculentum }\end{array}$ & soil & $\begin{array}{l}\text { film } \\
\text { mulch } \\
\text { DEHP }\end{array}$ & $\begin{array}{c}\text { pieces of } \\
12 \mathrm{~cm} \\
\text { diameter } \\
\text { and } 0.012 \\
\mathrm{~mm} \\
\text { thickness }\end{array}$ & $\begin{array}{l}0,6 \% \\
(w / w)\end{array}$ & 6 weeks & $\begin{array}{c}\text { - significant concentrations of DEHP accumulated by } \\
\text { Benincasa hispida, Cucumis sativus, Cucurbita moschata and } \\
\text { Brassica parachinensis } \\
\text { - concentrations raised in this later are close to the dietary } \\
\text { daily intake limit } \\
\text { - no phytotoxicty evaluated }\end{array}$ & 122 \\
\hline
\end{tabular}


Table 2. Summary table of the main techniques used for plastic characterization

\begin{tabular}{|c|c|c|c|c|c|c|c|c|c|}
\hline Technique & $\begin{array}{l}\text { Physical } \\
\text { principle }\end{array}$ & Type & $\begin{array}{l}\text { Chemical } \\
\text { specificity }\end{array}$ & $\begin{array}{c}\text { Resolu } \\
\text { tion }\end{array}$ & $\begin{array}{l}\text { Detection } \\
\text { limit }\end{array}$ & $\begin{array}{c}\text { Sample } \\
\text { preparation }\end{array}$ & Limitations & Obtained information & Ref. \\
\hline $\begin{array}{l}\text { scanning } \\
\text { electron } \\
\text { microscopy } \\
(\text { SEM })\end{array}$ & $\begin{array}{l}\text { electron } \\
\text { scattering }\end{array}$ & $\begin{array}{c}2 \mathrm{D} \\
\text { microscopy }\end{array}$ & $\begin{array}{l}\text { elemental } \\
\text { only if } \\
\text { coupled to } \\
\text { X-ray } \\
\text { emission } \\
\text { detection } \\
\text { (EDS) }\end{array}$ & few nm & $\begin{array}{l}\text { particle/ } \\
\text { particle } \\
\text { aggregate }\end{array}$ & $\begin{array}{l}\text { chemically fixed, } \\
\text { dehydrated, resin } \\
\text { embedded sample } \\
\text { and coated to } \\
\text { minimize surface } \\
\text { charging and } \\
\text { improve resolution }\end{array}$ & $\begin{array}{l}\text { - no chemical } \\
\text { specificity } \\
\text { - elemental } \\
\text { specificity if } \\
\text { coupled to EDS }\end{array}$ & $\begin{array}{c}\text { - particle localization } \rightarrow \text { mainly surface } \\
\text { association on phytoplankton based on } \\
\text { shape but not specific }\end{array}$ & $\begin{array}{c}33,35,36,38,39,41,4 \\
2,44,53,57,60,62,69 \\
, 70,73,74,81\end{array}$ \\
\hline $\begin{array}{l}\text { transmission } \\
\text { electron } \\
\text { microscopy } \\
\text { (TEM) }\end{array}$ & $\begin{array}{c}\text { electron } \\
\text { transmission }\end{array}$ & $\begin{array}{c}2 \mathrm{D} \\
\text { microscopy }\end{array}$ & $\begin{array}{l}\text { - elemental } \\
\text { only if } \\
\text { coupled to } \\
\text { EDS } \\
\text { - crystal line } \\
\text { phase if } \\
\text { coupled to } \\
\text { electron } \\
\text { diffraction } \\
\end{array}$ & $\mathrm{nm}$ & $\begin{array}{l}\text { particle/ } \\
\text { particle } \\
\text { aggregate }\end{array}$ & $\begin{array}{l}\text { chemically fixed, } \\
\text { dehydrated, resin } \\
\text { embedded sample } \\
\text { and sectioned to } \\
50-100 \mathrm{~nm} \\
\text { thickness to allow } \\
\text { electron } \\
\text { transmission }\end{array}$ & $\begin{array}{c}\text { - no chemical } \\
\text { specificity } \\
\text { - elemental } \\
\text { specificity if } \\
\text { coupled to EDS - } \\
\text { crystalline phase if } \\
\text { coupled to electron } \\
\text { diffraction }\end{array}$ & $\begin{array}{l}\text { - particle localization and cell } \\
\text { internalization in A. cepa based on } \\
\text { shape but not specific }\end{array}$ & 115 \\
\hline $\begin{array}{l}\text { fluorescence } \\
\text { microscopy }\end{array}$ & $\begin{array}{l}\text { UV-Vis } \\
\text { light } \\
\text { absorption } \\
\text { and } \\
\text { emission }\end{array}$ & $\begin{array}{c}2 \mathrm{D} \\
\text { microscopy }\end{array}$ & $\begin{array}{l}\text { fluorescence } \\
\text { specific to } \\
\text { the labelled } \\
\text { particle or } \\
\text { staining dye } \\
\text { molecule }\end{array}$ & $\begin{array}{c}100 \mathrm{~s} \text { of } \\
\mathrm{nm}\end{array}$ & $\begin{array}{c}\text { particle } \\
\text { aggregate }\end{array}$ & $\begin{array}{l}\text { - sectioning for } \\
\text { plant tissues } \\
\text { - applied on model } \\
\text { fluorescent plastics } \\
\text { or stained with } \\
\text { specific dyes (e.g. } \\
\text { oil red EGN, Eosin } \\
\text { B, Hostasol Yellow } \\
\text { 3G, Nile red and } \\
\text { Rose Bengal) }\end{array}$ & $\begin{array}{c}\text { - limited to } \\
\text { fluorescent labelled } \\
\text { plastic materials or } \\
\text { based on staining } \\
\text { protocols affected } \\
\text { by affinity to the } \\
\text { plastic of interest } \\
v s \text {. sample organic } \\
\text { component (e.g. } \\
\text { lignins, carotens in } \\
\text { plants) }\end{array}$ & $\begin{array}{c}\text { - interaction of micro and nanoplastics } \\
\text { with photosynthetic organisms } \\
\text { - evidence of aggregation with } \\
\text { phytoplankton } \\
\text { - internalization of micro and } \\
\text { nanoplastics in terrestrial plants }\end{array}$ & $\begin{array}{c}33,34,37,56,69,70,74 \\
107,115,103\end{array}$ \\
\hline $\begin{array}{l}\text { confocal laser } \\
\text { scanning } \\
\text { microscopy } \\
(\mathrm{CLSM})\end{array}$ & $\begin{array}{l}\text { UV-Vis } \\
\text { light } \\
\text { absorption } \\
\text { and } \\
\text { emission }\end{array}$ & $\begin{array}{c}3 \mathrm{D} \\
\text { microscopy }\end{array}$ & $\begin{array}{l}\text { fuorescence } \\
\text { specific to } \\
\text { the labelled } \\
\text { particle or }\end{array}$ & $\begin{array}{c}100 \mathrm{~s} \text { of } \\
\mathrm{nm}\end{array}$ & $\begin{array}{c}\text { particle } \\
\text { aggregate }\end{array}$ & $\begin{array}{l}\text { applied on model } \\
\text { fluorescent plastics } \\
\text { or stained with } \\
\text { specific dyes }\end{array}$ & $\begin{array}{c}\text { limited to } \\
\text { fluorescent labelled } \\
\text { plastic materials or } \\
\text { based on staining } \\
\text { protocols affected }\end{array}$ & $\begin{array}{c}\text { - 3D information is obtained } \\
\text { - nanoplastic association with } \\
\text { microalgae }\end{array}$ & $\begin{array}{c}42,53,60,62,69,70,7 \\
4,104,103,117\end{array}$ \\
\hline
\end{tabular}




\begin{tabular}{|c|c|c|c|c|c|c|c|c|c|}
\hline & & & $\begin{array}{l}\text { staining dye } \\
\text { molecule }\end{array}$ & & & & \begin{tabular}{|c|} 
by affinity to the \\
plastic of interest \\
$v s$. sample organic \\
component (e.g. \\
lignins, carotens in \\
plants) \\
\end{tabular} & $\begin{array}{l}\text { - presence of microplastics in the seed } \\
\text { capsules of terrestrial plants, and at later } \\
\text { stage in the root hairs (L. sativum) } \\
\text { - uptake of plastic nanoparticles in } \\
\text { roots (V.faba, T. aestivum) }\end{array}$ & \\
\hline $\begin{array}{l}\text { two-photon } \\
\text { excitation } \\
\quad \text { (time } \\
\text { resolved) } \\
\quad(\mathrm{TPE})\end{array}$ & $\begin{array}{l}\text { UV-Vis } \\
\text { light } \\
\text { absorption } \\
\text { and } \\
\text { emission }\end{array}$ & $\begin{array}{l}2 \mathrm{D} \\
\text { microscopy }\end{array}$ & $\begin{array}{l}\text { fluorescence } \\
\text { specific to } \\
\text { the labelled } \\
\text { particle }\end{array}$ & $60 \mu \mathrm{m}$ & $\begin{array}{l}\text { large } \\
\text { particle } \\
\text { aggregates }\end{array}$ & $\begin{array}{l}\text { no sample } \\
\text { preparation }\end{array}$ & $\begin{array}{c}\text { low resolution and } \\
\text { applied on long } \\
\text { fluorescence life } \\
\text { time labelled } \\
\text { plastics (e.g. Eu } \\
\text { doped) }\end{array}$ & $\begin{array}{c}\text { - non-invasive technique applied in vivo } \\
\text { - used for kinetic studies of Eu marked } \\
\text { nanoplastics in M. exotica }\end{array}$ & 120 \\
\hline $\begin{array}{l}\text { fluorescent } \\
\text { lifetime } \\
\text { imaging }\end{array}$ & $\begin{array}{l}\text { UV-Vis } \\
\text { light } \\
\text { absorption } \\
\text { and } \\
\text { emission } \\
\end{array}$ & $\begin{array}{l}2 \mathrm{D} \\
\text { microscopy }\end{array}$ & $\begin{array}{l}\text { fluorescence } \\
\text { specific to } \\
\text { the labelled } \\
\text { particle }\end{array}$ & $\begin{array}{c}100 \mathrm{~s} \text { of } \\
\mathrm{nm}\end{array}$ & $\begin{array}{l}\text { particle } \\
\text { aggregate }\end{array}$ & $\begin{array}{l}\text { no sample } \\
\text { preparation }\end{array}$ & $\begin{array}{l}\text { applied on long } \\
\text { fluorescence life } \\
\text { time labelled } \\
\text { plastics (e.g. Eu } \\
\text { doped) } \\
\end{array}$ & $\begin{array}{l}\text { - cell wall deposition of nanoplastics in } \\
\text { the lignified epidermis of } M \text {. exotica }\end{array}$ & 120 \\
\hline $\begin{array}{l}\text { Fourier } \\
\text { transformed } \\
\text { infrared } \\
\text { spectroscopy } \\
\text { (FTIR) }\end{array}$ & $\begin{array}{c}\text { infrared } \\
\text { light } \\
\text { absorption } \\
\text { of molecular } \\
\text { bond dipoles }\end{array}$ & $\begin{array}{l}2 \mathrm{D} \\
\text { microscopy/ } \\
\text { bulk solids }\end{array}$ & $\begin{array}{l}\text { chemical } \\
\text { functional } \\
\text { groups } \\
\text { (polar } \\
\text { bonds) }\end{array}$ & $10 \mu \mathrm{m}$ & $\begin{array}{c}\text { particle } \\
\text { aggregate }\end{array}$ & \begin{tabular}{|} 
- bulk solids require \\
extraction, filtration \\
or separation \\
protocols \\
- microscopy \\
requires resin \\
embedding and \\
microtome \\
sectioning
\end{tabular} & \begin{tabular}{|c|} 
- water \\
interference, \\
samples must be IR \\
active and the \\
acquisition is slow \\
if the objective is to \\
identify individual \\
micro-particles and \\
obtain FTIR \\
spectra. \\
\end{tabular} & $\begin{array}{c}\text { - chemical changes in the plastic } \\
\text { material induced by aging in the } \\
\text { environment } \\
\text { - carbonyl oxidation in lead chromated } \\
\text { microplastics } \\
\text { - photo-oxidative degradation in some } \\
\text { microparticles }\end{array}$ & $62,67,81$ \\
\hline $\begin{array}{l}\text { Raman } \\
\text { spectroscopy }\end{array}$ & $\begin{array}{l}\text { inelastic } \\
\text { light } \\
\text { scattering } \\
\text { from } \\
\text { chemical } \\
\text { bonds }\end{array}$ & $\begin{array}{l}2 \mathrm{D} \\
\text { microscopy/ } \\
\text { bulk solids }\end{array}$ & $\begin{array}{l}\text { chemical } \\
\text { functional } \\
\text { groups }\end{array}$ & $300 \mathrm{~nm}$ & $\begin{array}{l}\text { particle } \\
\text { aggregate }\end{array}$ & \begin{tabular}{|c|} 
- bulk solids require \\
extraction, filtration \\
or separation \\
protocols \\
- microscopy \\
requires resin \\
embedding and \\
microtome \\
sectioning. \\
\end{tabular} & \begin{tabular}{|} 
- low scattering \\
yield affects \\
detection limit in \\
bulk solid analysis \\
- sample \\
autofluorescence \\
complicates \\
detection in
\end{tabular} & $\begin{array}{c}\text { - microplastic structure remain stable } \\
\text { during aging ( } 4 \text { weeks at } 50 \% \text { humidity, } \\
60^{\circ} \mathrm{C} \text {, and } 1200 \mathrm{~W} \mathrm{~m}^{-2} \text { irradiance) }\end{array}$ & 67 \\
\hline
\end{tabular}




\begin{tabular}{|c|c|c|c|c|c|c|c|c|c|}
\hline & & & & & & $\begin{array}{l}\text { - confocal Raman } \\
\text { microscopy can be } \\
\text { applied in non- } \\
\text { sectioned samples } \\
\end{array}$ & $\begin{array}{l}\text { microscopy } \\
\text { applications }\end{array}$ & & \\
\hline $\begin{array}{l}\text { flow } \\
\text { cytometry }\end{array}$ & $\begin{array}{l}\text { light } \\
\text { absorption } \\
\text { and } \\
\text { emission }\end{array}$ & $\begin{array}{c}\text { bulk } \\
\text { suspension }\end{array}$ & $\begin{array}{l}\text { fluorescence } \\
\text { specific to } \\
\text { the labelled } \\
\text { particle or } \\
\text { staining dye } \\
\text { molecule }\end{array}$ & $\begin{array}{l}\text { individ } \\
\text { ual } \\
\text { cells }\end{array}$ & $\begin{array}{l}\text { aggregates } \\
\text { on cells }\end{array}$ & $\begin{array}{l}\text { suspension } \\
\text { dilutions }\end{array}$ & $\begin{array}{c}\text { - limited to } \\
\text { fluorescent labelled } \\
\text { plastic materials or } \\
\text { based on staining } \\
\text { protocols affected } \\
\text { by affinity to the } \\
\text { plastic of interest } \\
v s \text {. sample organic } \\
\text { component (e.g. } \\
\text { lignins, carotens in } \\
\text { plants) } \\
\end{array}$ & $\begin{array}{l}\text { - microplastic quantification in } \\
\text { microalgal cultures } \\
\text { - distinction between free suspended } \\
\text { microplastics, hetero-aggregates, and } \\
\text { microalgae }\end{array}$ & 51 \\
\hline $\begin{array}{l}\text { dynamic light } \\
\text { scattering } \\
\text { (DLS) }\end{array}$ & $\begin{array}{l}\text { UV-Vis } \\
\text { light } \\
\text { scattering }\end{array}$ & $\begin{array}{c}\text { bulk } \\
\text { suspension }\end{array}$ & $\begin{array}{l}\text { no chemical } \\
\text { information }\end{array}$ & $\begin{array}{l}\text { hydrod } \\
\text { ynamic } \\
\text { diamet } \\
\text { er } 0.7- \\
10 \mu \mathrm{m}\end{array}$ & $\begin{array}{l}\text { dispersed } \\
\text { particles at } \\
\text { ppm level }\end{array}$ & $\begin{array}{l}\text { suspension } \\
\text { dilutions }\end{array}$ & \begin{tabular}{|c|} 
- average \\
hydrodynamic size \\
and surface charge \\
- does not provide \\
reliable results on \\
polydispersed \\
suspensions \\
\end{tabular} & $\begin{array}{l}\text { - mainly used for pre-characterization } \\
\text { of particles in exposure media }\end{array}$ & $\begin{array}{l}\text { used in } 60 \% \\
\text { of the } \\
\text { studies cited } \\
\text { in this } \\
\text { review }\end{array}$ \\
\hline $\begin{array}{l}\text { electron } \\
\text { paramagnetic } \\
\text { resonance } \\
(\mathrm{EPR})\end{array}$ & $\begin{array}{c}\text { magnetic } \\
\text { electron spin } \\
\text { transitions }\end{array}$ & $\begin{array}{c}\text { bulk } \\
\text { suspension }\end{array}$ & $\begin{array}{l}\text { electronic } \\
\text { structure in } \\
\text { paramagneti } \\
\text { c } \\
\text { compounds }\end{array}$ & $\mathrm{n} / \mathrm{a}$ & ppm & $\begin{array}{l}\text { suspension } \\
\text { dilutions }\end{array}$ & $\begin{array}{c}\text { - average } \\
\text { paramagnetic } \\
\text { electronic } \\
\text { transitions } \\
\text { - use of } \\
\text { paramagnetic } \\
\text { compounds }\end{array}$ & $\begin{array}{l}\text { - investigate the associations of marine } \\
\text { phytoplankton and plastics in seawater } \\
\text { (S. marinoi, L. polyedrum) }\end{array}$ & 68 \\
\hline $\begin{array}{c}\text { high } \\
\text { performance } \\
\text { liquid } \\
\text { chromatograp } \\
\text { hy } \\
\text { (HPLC) }\end{array}$ & $\begin{array}{c}\text { ionization } \\
\text { and mass } \\
\text { spectrometry }\end{array}$ & $\begin{array}{l}\text { bulk } \\
\text { solution }\end{array}$ & $\begin{array}{l}\text { mass to } \\
\text { charge ratio } \\
\text { of ionized } \\
\text { fragmented } \\
\text { compound }\end{array}$ & $\mathrm{n} / \mathrm{a}$ & sub-ppm & $\begin{array}{c}\text { digestion/extraction } \\
\text {, filtration and/or } \\
\text { separation } \\
\text { protocols }\end{array}$ & $\begin{array}{c}\text { - average chemical } \\
\text { composition } \\
\text { - destructive } \\
\text { technique }\end{array}$ & $\begin{array}{c}\text { - identification of plasticizer and } \\
\text { stabilizer molecules in leachates of } \\
\text { microplastics } \\
\text { - high-throughput screening of leachate } \\
\text { molecules from plastics }\end{array}$ & 56,65 \\
\hline
\end{tabular}




\begin{tabular}{|c|c|c|c|c|c|c|c|c|c|}
\hline $\begin{array}{c}\text { gas } \\
\text { chromatograp } \\
\text { hy } \\
\text { (GC) }\end{array}$ & $\begin{array}{c}\text { ionization } \\
\text { and mass } \\
\text { spectrometry }\end{array}$ & $\begin{array}{l}\text { bulk } \\
\text { solution }\end{array}$ & $\begin{array}{c}\text { mass to } \\
\text { charge ratio } \\
\text { of ionized } \\
\text { fragmented } \\
\text { compound }\end{array}$ & $\mathrm{n} / \mathrm{a}$ & sub-ppm & $\begin{array}{l}\text { digestion/extraction } \\
\text {, filtration and/or } \\
\text { separation } \\
\text { protocols }\end{array}$ & $\begin{array}{l}\text { - average chemical } \\
\text { composition } \\
\text { - destructive } \\
\text { technique }\end{array}$ & $\begin{array}{l}\text { - identification of marine water } \\
\text { leachates produced by different types of } \\
\text { microplastics }\end{array}$ & 64 \\
\hline $\begin{array}{l}\text { inductively } \\
\text { coupled } \\
\text { plasma } \\
\text { (ICP-MS) }\end{array}$ & $\begin{array}{c}\text { ionization } \\
\text { and mass } \\
\text { spectrometry }\end{array}$ & $\begin{array}{l}\text { bulk } \\
\text { solution }\end{array}$ & $\begin{array}{l}\text { elemental } \\
\text { composition } \\
\text { / element } \\
\text { isotopes }\end{array}$ & $\mathrm{n} / \mathrm{a}$ & sub-ppm & $\begin{array}{l}\text { digestion/extraction } \\
\text {, filtration and/or } \\
\text { separation } \\
\text { protocols }\end{array}$ & $\begin{array}{l}\text { - average chemical } \\
\text { composition } \\
\text { - destructive } \\
\text { technique }\end{array}$ & $\begin{array}{l}\text { - elemental associations with plastics } \\
\qquad(\mathrm{Cu}, \mathrm{Zn} \text { and } \mathrm{Sr}) \\
\text { - potential use for indirect detection of } \\
\text { plastics (doped with metals) }\end{array}$ & $64,65,129,130$ \\
\hline $\begin{array}{c}\text { pyrolysis gas } \\
\text { chromatograp } \\
\text { hy } \\
\text { (py-GC-MS) }\end{array}$ & $\begin{array}{c}\text { ionization } \\
\text { and mass } \\
\text { spectrometry }\end{array}$ & bulk solid & $\begin{array}{c}\text { mass to } \\
\text { charge ratio } \\
\text { of ionized } \\
\text { fragmented } \\
\text { compound }\end{array}$ & $\mathrm{n} / \mathrm{a}$ & sub-ppm & $\begin{array}{l}\text { isolation of plastic } \\
\text { particles/ bulk solid }\end{array}$ & $\begin{array}{l}\text { - average chemical } \\
\text { composition } \\
\text { - destructive } \\
\text { technique }\end{array}$ & $\begin{array}{l}\text { - identification of polymer types and } \\
\text { additives in marine microplastics }\end{array}$ & 137 \\
\hline
\end{tabular}

